ANA LUIZA DE FIGUEIREDO STEINER

PROFISSIONAIS DE SAÚDE NA RELAÇÃO COM OS

PACIENTES PORTADORES DE ESCLEROSE LATERAL AMIOTRÓFICA : ASPECTOS PSICOLÓGICOS E DE QUALIDADE DE VIDA

São Paulo 2008 
ANA LUIZA DE FIGUEIREDO STEINER

\section{PROFISSIONAIS DE SAÚDE NA RELAÇÃO COM OS PACIENTES PORTADORES DE ESCLEROSE LATERAL AMIOTRÓFICA: ASPECTOS PSICOLÓGICOS E DE QUALIDADE DE VIDA}

Dissertação apresentada ao Instituto de Psicologia da Universidade de São Paulo, como parte dos requisitos para obtenção do grau de Mestre em Psicologia.

Área de Concentração: Psicologia Clínica

Orientadora: Prof $^{\mathrm{ra}}$. Associada

Leila Salomão De La Plata Cury Tardivo

São Paulo

2008 
AUTORIZO A REPRODUÇÃO E DIVULGAÇÃO TOTAL OU PARCIAL DESTE TRABALHO, POR QUALQUER MEIO CONVENCIONAL OU ELETRÔNICO, PARA FINS DE ESTUDO E PESQUISA, DESDE QUE CITADA A FONTE.

Catalogação na publicação

Serviço de Biblioteca e Documentação

Instituto de Psicologia da Universidade de São Paulo

Steiner, Ana Luiza.

Profissionais de saúde na relação com os pacientes portadores de esclerose lateral amiotrófica: aspectos psicológicos e de qualidade de vida / Ana Luiza Steiner; orientadora Leila Salomão De La Plata Cury Tardivo. -- São Paulo, 2008.104 p.

Dissertação (Mestrado - Programa de Pós-Graduação em Psicologia. Área de Concentração: Psicologia Clínica) - Instituto de Psicologia da Universidade de São Paulo.

1. Esclerose amiotrófica lateral 2. Profissionais da saúde 3. Relações interpessoais 4. Teste de Rorschach 5. Qualidade de vida 6. Afeição I. Título. 
PROFISSIONAIS DE SAÚDE NA RELAÇÃO COM OS PACIENTES PORTADORES DE ESCLEROSE LATERAL AMIOTRÓFICA: ASPECTOS PSICOLÓGICOS E DE QUALIDADE DE VIDA

ANA LUIZA DE FIGUEIREDO STEINER

BANCA EXAMINADORA

Presidente e Orientadora: Leila Salomão de La Plata Cury Tardivo

Nome e Assinatura

Nome e Assinatura

Dissertação defendida e aprovada em : 
A minha filha Mariana, pelo carinho e força.

A minha mãe, meu modelo e eterna amiga.

Aos meus familiares, amigos, presentes e ausentes. 


\section{AGRADECIMENTOS}

Gostaria de iniciar os meus agradecimentos à Prof. a Associada Leila Salomão Cury Tardivo, minha orientadora e amiga, pela imensa disponibilidade de esclarecer, orientar, acolher e apoiar. Agradeço sua confiança em compartilhar seu sonho comigo na formação e crescimento do Laboratório APOIAR.

Ao Dr Acaray Souza Bulle Oliveira, professor afiliado da Neurologia e responsável pelo setor de doenças neuromusculares da Universidade Federal de São Paulo/ Escola Paulista de Medicina, abrindo as portas do Ambulatório da Neuromuscular, sempre nos incentivando, nos dando retaguarda e contribuindo para a realização deste trabalho.

A prof. ${ }^{a}$ Dra. Helga Cristina Almeida Silva, professora orientadora da pós graduação da Neuromuscular pela orientação, apoio, confiança e carinho sempre presentes em nossa relação.

A Abrahão Quadros, presidente da ABRELA, pelo apoio e incentivo na realização deste trabalho.

Ao meu amigo e parceiro do Projeto ABRELA/APOIAR, Antônio Geraldo Abreu Filho, pelo carinho, apoio e amizade e de compartilhar comigo a realização e crescimento do nosso trabalho.

Aos meus colegas e amigos do Laboratório Apoiar, pela amizade e incentivo sempre presentes.

A Arlete, Claudia e Cícera, secretárias da Psicologia Clínica, pela grande ajuda e disponibilidade em todos os momentos que foram necessários. 
Aos profissionais de saúde da ABRELA, que autorizaram a realização desta pesquisa que, pela confiança em mim depositada, permitiram a realização deste trabalho.

Aos colegas e amigos da parceria ABRELA/ UNIFESP-Neuromuscular, pelo apoio e confiança em nosso trabalho.

A Dirce Dias Sobral Ribeiro, secretária da Neuromuscular, pela disponibilidade e carinho.

A Maria Cristina Pellini, pela amizade, pela supervisão nas avaliações de Rorschach, sempre me incentivando e me forçando a dar o melhor de mim.

Ao meu supervisor clínico e amigo Rafael Tassinari, que me acompanha há anos o meu desenvolvimento pessoal e profissional.

Aos amigos e colegas do Centro de Convivência do Parque Ibirapuera, por fazerem parte da minha vida.

A memória de minha mãe, meu pai, minha sobrinha Juliana e de Patrícia que com certeza estão comigo neste momento.

A minha irmã Claudia, pelo apoio e carinho em me auxiliar na revisão dos originais e resumo em inglês.

A minha irmã Sylvia, pelo amor sempre presente, mesmo estando distante fisicamente.

Aos meus sobrinhos, sobrinhas, sobrinhos netos, pela esperança no futuro.

E a minha filha, por ser quem é. 
"O correr da vida embrulha tudo.

A vida é assim: esquenta e esfria, Aperta e daí afrouxa, Sossega e depois desinquieta.

O que ela quer da gente é coragem."

João Guimarães Rosa 
SUMÁRIO

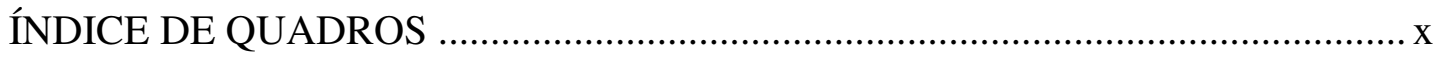

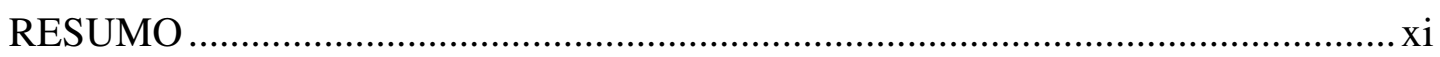

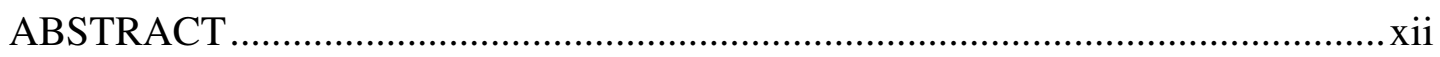

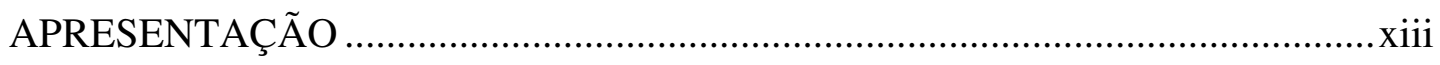

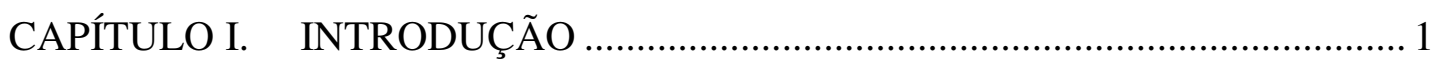

I.1. ESCLEROSE LATERAL AMIOTRÓFICA (ELA) ...................................... 1

I.2. A RELAÇÃO PACIENTE - PROFISSIONAL DE SAÚDE....................... 2

I.2.1. PROCESSO DE ADOECER E A NOÇÃO DE SOFRIMENTO........... 2

I.2.2. A DOENÇA E OS PROFISSIONAIS DE SAÚDE............................. 5

I.3. A ENFERMIDADE E OS MECANISMOS DE DEFESAS ....................... 9

I.4. A RELAÇÃO PROFISSIONAL DE SAÚDE - PACIENTE TRANSFERÊNCIA E CONTRATRANSFERÊNCIA ............................................ 13

I.5. O CONCEITO DE QUALIDADE DE VIDA E O CONTATO COM AS

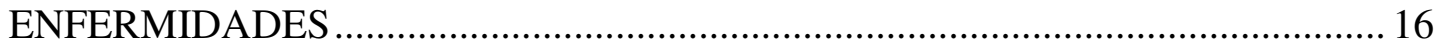

CAPÍTULO II. JUSTIFICATIVA E OBJETIVOS …......................................... 18

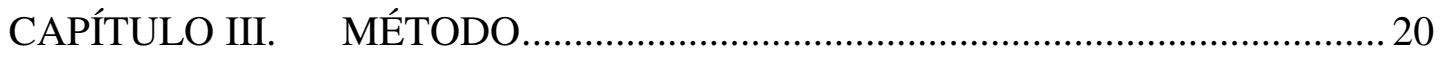

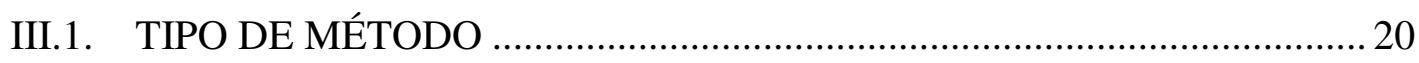

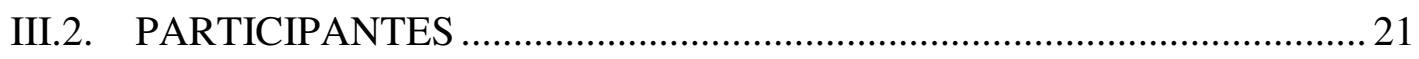

III.3. INSTRUMENTOS E PROCEDIMENTOS …............................................. 22

III.3.1. ENTREVISTA PSICOLÓGICA SEMI ESTRUTURADA................... 23

III.3.2. MÉTODO DE RORSCHACH - SISTEMA DE AVALIAÇÃO

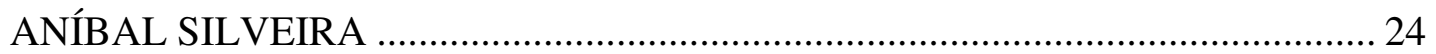

III.3.3. QUESTIONÁRIO DE QUALIDADE DE VIDA MCGILL ................ 39 CAPÍTULO IV. APRESENTAÇÃO E DISCUSSÃO DOS RESULTADOS ... 41

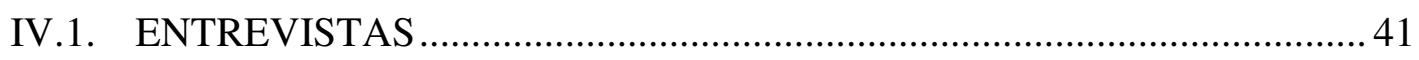

IV.2. RESULTADOS DOS ÍNDICES DO RORSCHACH................................ 60

IV.3. QUESTONÁRIO DE QUALIDADE DE VIDA DE McGill .................... 73

CAPÍTULO V. SÍNTESE E CONSIDERAÇÕES FINAIS ............................... 79

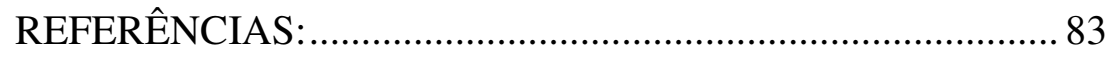

ANEXOS .89 


\section{ÍNDICE DE QUADROS}

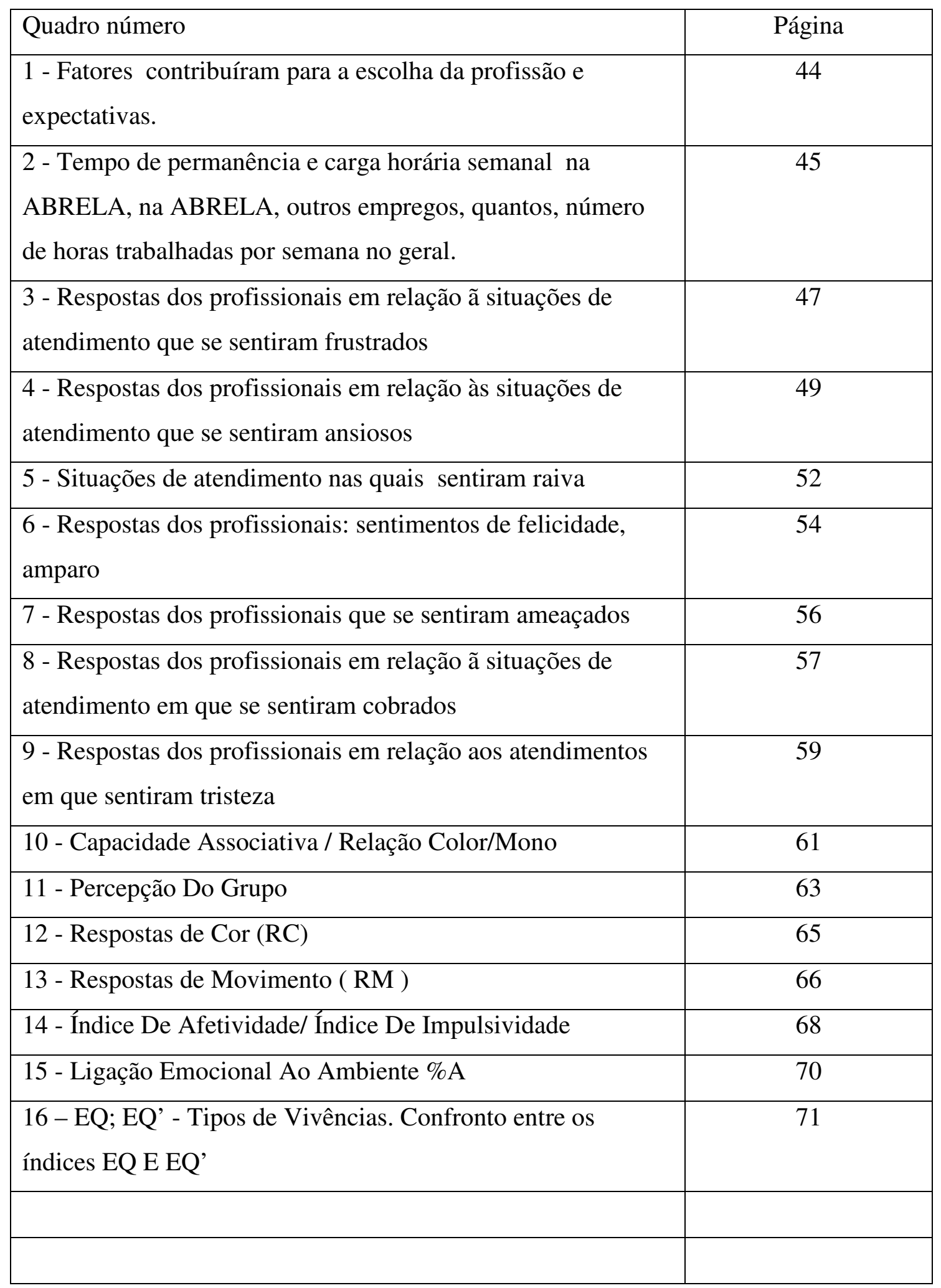




\section{RESUMO}

STEINER, Ana Luiza - PROFISSIONAIS DE SAÚDE NA RELAÇÃO COM OS PACIENTES PORTADORES DE ESCLEROSE LATERAL AMIOTRÓFICA: ASPECTOS PSICOLÓGICOS E DE QUALIDADE DE VIDA. São Paulo, 2008,108p. Dissertação de Mestrado - Instituto de Psicologia da Universidade de São Paulo.

Esta pesquisa se desenvolveu a partir da parceria entre o Projeto APOIAR do Laboratório de Saúde Mental e Psicologia Clinica Social do Instituto de Psicologia da USP e a ABRELA (Associação Brasileira de Esclerose Lateral Amiotrófica). O estudo refere-se à investigação e compreensão de aspectos afetivos, emocionais e de qualidade de vida dos profissionais da área de saúde, enfocando sua relação com cuidadores e pacientes portadores de Esclerose Lateral Amiotrófica (ELA), doença degenerativa dos neurônios motores, sem prognóstico de cura, embora com a consciência mantida até a morte. Foi empregado o método clínico de pesquisa em onze profissionais, médicos, assistentes sociais, fisioterapeutas respiratórios e motor, nutricionista e terapeuta ocupacional, no setor da Neuromuscular da UNIFESP/Escola Paulista de Medicina em parceria com a ABRELA. Foram empregados como instrumentos: Entrevista Psicológica Semi Estruturada, Método de Rorschach pelo Sistema de Avaliação Aníbal Silveira (sendo alguns índices selecionados) e o Questionário de Vida de McGill. Os dados foram tratados considerando o grupo de forma geral e não de modo individualizado. Principais resultados obtidos apontam para a maturidade do grupo de profissionais, a sensibilidade da maioria à dor e ao sofrimento dos pacientes, com respostas que denotam afetividade, frustração diante da falta de cura e sucesso no tratamento. Demonstram qualidade de vida preservada, e os dados sugerem que trabalham na área que escolheram apesar das dificuldades que sentem. Sugere-se que sejam implementados programas que possam dar aos profissionais de saúde o suporte necessário para que se mantenham como o grupo estudado nessa pesquisa, em condições de dar conta do contato com pacientes com enfermidades graves e crônicas como a ELA.

Palavras Chave; Esclerose Lateral Amiotrófica (ELA); relação profissional de saúde - paciente; aspectos afetivos; Método de Rorschach; Qualidade de Vida 


\begin{abstract}
STEINER, Ana Luiza - Health Professionals and their relationship with ALS patients,Psychological aspects and Quality of Life. São Paulo, 2008, 108p. Master Thesis. Institute of Psychology of University of Sao Paulo.
\end{abstract}

The actual research was possible due to the partnership between the Project APOIAR (SUPPORT) of the Laboratory of Mental Health and Clinical Psychology of the Institute of Psychology of USP - University of Sao Paulo, and ABRELA ( Brazilian Association of Amyotrophic Lateral Sclerosis ( ALS ).

This study intends to investigate and better understand the Quality of Life and emotional aspects of health professionals in their relationship with ALS patients and their carers. ALS is a degenerative illness which affects motor neurons causing severe physical impediments, even tough its patients continue lucid up to their death. This illness does not have a prognosis of cure.

We have applied the Clinical Method of survey and research on eleven professionals - physicians, social workers, motor and respiratory physiotherapists, nutritionist and occupational therapist from de Department of neuromuscular of UNIFESP/ Federal Paulista Medical School and partnership with ABRELA.

The study Instruments used were the Semi- Structured psychological Interview, the Rorschach Method ( the Evaluation System by Anibal Silveira) and the Questionnaire of Quality of Life. The collected data considered the group as a whole and not individuals.

The main results point towards the maturity of the group of health professionals and their sensitivity related to the pain and suffering of patients, with answers showing affection and frustration due to impossibility of cure and success of treatment. The results show preserved Quality of Life and suggest that those health professionals work within their chosen specialty despite their difficulties. The study suggests the need of implementing programs which give health professionals the necessary support, as shown in this study, so that they can deal with their patients with serious and chronic illnesses such ALS.

Key - words : Amyotrophic Lateral Sclerosis (ALS); Relation health professional-patient; affection aspects; Rosrschach Method; Quality of Life 


\section{APRESENTAÇÃO}

O presente trabalho reflete minha trajetória profissional como Educadora em Saúde Pública e Psicóloga Clínica, percorrido no decorrer destes quase trinta anos, em diversas áreas de atendimento, como parte integrante de equipes de saúde pública e mental, tanto nas Secretarias de Saúde do Estado como da Prefeitura do Município de São Paulo, assim como em meu consultório.

Buscando novos caminhos que permitissem refletir e ampliar minha experiência clínica e profissional, em 2003 comecei a participar do Laboratório APOIAR, Atendimento Psicológico Clínico Individual e Grupal do Instituto de Psicologia da Universidade de São Paulo, coordenado pela Prof. a Associada Leila Cury Tardivo, participando da recém formada parceria entre a ABRELA, Associação Brasileira de Esclerose Lateral Amiotrófica e o Laboratório APOIAR.

Essa parceria originou-se de um encontro entre a Prof. ${ }^{a}$ Dra. Helga Cristina Almeida Silva, presidente, na época, da referida Associação, com a Prof. a Associada Leila Cury Tardivo. O principal propósito do encontro foi o de minorar o sofrimento psíquico dos pacientes portadores de ELA, familiares, cuidadores e profissionais de saúde, e buscar um apoio psicológico para este grupo.

Portanto, na busca de minorar o sofrimento psíquico dos pacientes portadores de ELA, de seus cuidadores, familiares e profissionais da área de saúde que lidam com esta doença, foi efetivada a parceria entre o APOIAR e a ABRELA.

O APOIAR - Atendimento Psicológico Clínico Individual e Grupal, faz parte integrante do Laboratório de Saúde Mental e Psicologia Clínica Social do Instituto de Psicologia da Universidade de São Paulo (IPUSP).

Coordenado pela Prof. a Associada Leila Tardivo, possui como objetivo básico propiciar um espaço interinstitucional de estudos e pesquisas voltadas para a formação do psicólogo clínico como trabalhador de saúde mental, além de propor atendimentos clínicos diferenciados sob uma perspectiva psicanaliticamente orientada. (Tardivo, 2003).

Esta perspectiva abriga diversas propostas de atendimento, estabelecendo parcerias com instituições que necessitam de suporte psicológico e desenvolvendo projetos de pesquisa, sempre reunidos nesta mesma linha: estudo e compreensão de 
indivíduos em sofrimento e as possíveis intervenções que podem ser desenvolvidas a partir de uma proposta de Psicologia Clínica Social. Todas as propostas e atividades de pesquisa estão sempre vinculadas à prática clínica, sendo que o Laboratório conta com a participação de Docentes do Instituto, de estudantes de pós-graduação, de graduação e colaboradores. (Tardivo, 2003).

Os objetivos que norteiam o Laboratório Apoiar encontram-se alinhados aos da ABRELA, entidade esta que trabalha em forma de parceria com instituições de ensino e pesquisa organizando, realizando e participando de seminários, congressos nacionais e internacionais, visando assim divulgar informações sobre a ELA e seu tratamento, bem como oferecer treinamento continuado aos profissionais de saúde. Outra importante parceria estabelecida pela ABRELA é com o setor de Doenças Neuromusculares do Departamento de Neurologia da Universidade Federal de São PAULO/ Escola Paulista de Medicina, o qual colabora com os atendimentos dos pacientes portadores de ELA.

Sua missão é definida como sendo a de promover uma melhor qualidade de vida aos pacientes com Esclerose Lateral Amiotrófica, por meio de informação, orientação e apoio social ao paciente e familiar, bem como divulgar informações à sociedade e aos profissionais interessados na doença e em seu tratamento. (INFORMATIVO ABRELA, 2007).

Portanto, a partir deste encontro, a parceria foi formalizada possibilitando de imediato, a estruturação de um projeto denominado de Projeto Tutor. Este consiste no atendimento domiciliar aos pacientes com ELA, realizado por alunos de graduação de psicologia do IPUSP, coordenados por mim e pelo doutorando Antonio Geraldo de Abreu Filho com a supervisão da prof. a Associada Leila Cury Tardivo.

A parceria APOIAR/ABRELA já realizou, também, diversas pesquisas e trabalhos que foram levados para congressos nacionais, internacionais, seminários, simpósios e mesa redonda, contribuindo assim para ampliar pesquisas sobre a Esclerose Lateral Amiotrófica, doença ainda bastante desconhecida em nosso meio e para ressaltar o quanto é de extrema importância considerar os aspectos afetivos e emocionais não só nos pacientes portadores de ELA e respectivos cuidadores como também nos profissionais de saúde que trabalham com estes pacientes. Dentre esses trabalhos, destacamos o de Barcelona, Espanha, no XVIII Congresso Internacional 
de Rorschach e Métodos Projetivos, em julho de 2005,intitulado El Estúdio de la personalidad de um paciente portador de ELA com el uso del método de Rorschach; comparaciones entre los sistemas de evaluacion de Aníbal Silveira y el sistema Comprensivo de Exner e o trabalho Estúdio Comparativo da dinâmica afectivoemocional de uma paciente portadora de esclerose lateral amiotrófica(ELA) e de su cuidador através do Test de Rorschach, apresentado no XIII Congresso Latinoamericano de Rorschach e Métodos Projetivos, em 2006, Lima Peru.Ambos fazem uma análise da dinâmica afetivo e emocional dos pacientes estudados e do cuidador, apontando para a necessidade destes aspectos serem levados em conta pelos profissionais de saúde que lidam com esta doença.

Sendo assim, o presente trabalho é também decorrente dessa mesma parceria APOIAR/ABRELA e enfoca a equipe de profissionais da área de saúde nos seus aspectos afetivos e nas relações que estes profissionais estabelecem com os pacientes portadores de ELA e respectivos cuidadores. Essa equipe é composta por médicos neurologistas, assistente sociais, terapeuta ocupacional, fisioterapeutas motor e respiratório, nutricionistas, psicólogos e fonoaudiólogos. Esses profissionais são na sua maioria alunos de mestrado, doutorado e especialização e estão vinculados à parceria ABRELA/NEUROMUSCULAR-UNIFESP/ESCOLA PAULISTA DE MEDICINA.

A oportunidade de realizar o presente trabalho foi extremamente gratificante, pois, além de proporcionar uma reflexão sobre de que maneira os profissionais de saúde lidam com seus afetos e como estes repercutem no relacionamento com os pacientes, também nos remeteu a pensar em nosso papel, enquanto psicólogos clínicos, frente a estas vivências de sofrimento por parte não só do paciente como também dos profissionais.

O método que utilizamos neste trabalho foi o clínico, utilizando como instrumentos as entrevistas semi estruturadas, o Método de Rorschach e o Questionário Qualidade de Vida McGill.

A seguir, descrevemos, de forma sucinta, como esse texto foi organizado em capítulos.

O capítulo I, dedicado à INTRODUÇÃO, contem temas que fundamentam a presente pesquisa. Assim, iniciamos com uma breve definição da Esclerose Lateral 
Amiotrófica como sendo uma doença degenerativa e progressiva dos neurônios motores, não havendo prognóstico de cura. Podemos afirmar que esta doença aprisiona a pessoa em si mesma, rompendo gradativamente sua ligação com o mundo exterior, gerando um imenso sofrimento psíquico, não só para o paciente, mas para todos com ele envolvidos; cuidadores, familiares e os profissionais de saúde que lidam com esta doença.

Incluímos uma discussão da noção de sofrimento, e nos remetemos ao conceito de Barus Michel (2001). Ainda apresentamos uma análise do significado da doença por diversos autores, que de forma geral, apresentam a enfermidade como um fator de ruptura da estabilidade psíquica. Discutimos as reações do paciente e também dos cuidadores quanto à situação de enfermidade, em especial as graves, e abordamos os mecanismos de defesas como reação e possibilidade de se restaurar a função homeostática do aparelho psíquico. Ao analisar os principais e mais comuns mecanismos de defesas, pretendemos ampliar nossa compreensão sobre como estes mecanismos vão influenciar na relação dos pacientes com os profissionais. Discutimos, também, os aspectos transferenciais e contra transferenciais presentes nessa relação, como em qualquer outra relação terapêutica.

Concluímos a Introdução com uma breve discussão sobre o conceito de Qualidade de Vida, o qual foi também objeto dessa pesquisa.

No capítulo II apresentamos as justificativa do estudo, que se apresenta como inédito, e os objetivos da pesquisa que deu origem à essa Dissertação.

O capítulo III é dedicado aos aspectos metodológicos empregados na pesquisa. Descrevemos o método clínico, os participantes, os procedimentos e os instrumentos utilizados. Assim, empregamos entrevistas semi estruturadas, o método de Rorschach na avaliação Aníbal Silveira, para a compreensão dos aspectos afetivo emocionais. e o Questionário de Qualidade de Vida da McGill para a avaliação da qualidade de vida. Os instrumentos foram aplicados pela autora da pesquisa de forma 
individual e, após avaliação de cada instrumento, foi realizada uma análise considerando o grupo de forma geral.

No capítulo IV são apresentados e discutidos os resultados obtidos a partir dos três instrumentos, onde empreendemos uma reflexão dos principais dados obtidos e comparamos nossas observações com as principais colocações trazidas por autores na Introdução.

Em seguida, trazemos, no quinto capítulo, uma síntese dos dados que nos pareceram mais relevantes e, ainda, as considerações finais dessa dissertação, com uma breve conclusão do presente estudo, considerando ainda, que tais pesquisas devem prosseguir.

Inserimos as referências utilizadas para o estudo e, finalmente, os anexos citados ao longo do texto. 


\section{CAPÍTULO I. - INTRODUÇÃO}

\section{I.1. ESCLEROSE LATERAL AMIOTRÓFICA (ELA)}

A Esclerose Lateral Amiotrófica (ELA) faz parte do grupo das doenças do neurônio motor e caracteriza-se pela degeneração progressiva dos neurônios motores do cérebro, tronco encefálico e da medula espinhal, não havendo ainda prognóstico de cura. Há diversas formas de apresentação clínica da doença, mas a mais encontrada é a forma clássica, correspondente a $56 \%$ de incidência e que se inicia pelos membros superiores.( Manual de Informação,2007).

Os primeiros sinais clínicos são fraqueza muscular, fasciculação e atrofia muscular. Posteriormente há o comprometimento dos pares cranianos. Outra forma é a bulbar, em torno de $28 \%$ dos casos, cujo início se dá pela paralisia da musculatura lábio-glosso-laríngea, tendo como conseqüência a disfonia, dispnéia, disfagia, dificuldade para engolir, atrofia e fasciculações na língua. Secundariamente há o envolvimento de membros superiores, inferiores e tronco, com evolução para óbito geralmente em um ano. A forma familiar, 5 a $10 \%$ dos casos em que atinge os adultos mais jovens, a progressão da doença é mais lenta.

O diagnóstico da doença é baseado nos sintomas relatados pelos pacientes e por exames neurológicos. Há uma prevalência de 6 por 100.000 pessoas e o início da doença é geralmente entre 40 e 60 anos de idade, sendo mais freqüente o sexo masculino. A ELA possui duas fases bem nítidas, denominadas de pré-clínica e clínica. Na pré-clínica, acredita-se haver susceptibilidade genética determinada e que, ao entrar em contato com agente agressor, inicia-se o processo degenerativo. $\mathrm{Na}$ fase clínica, há o período pré-sintomático, onde clinicamente não há nenhum sintoma, mas já estão presentes alterações laboratoriais, e o sintomático, com os sintomas já descritos anteriormente. Porém no exame anátomo - patológico, desde o período pré-sintomático, já aparece à degeneração dos neurônios motores e, no exame neurofisiológico, a alteração das unidades motoras (neurônio da medula espinhal-nervo-músculo). Nas diversas formas de manifestação da doença, a fraqueza muscular é um dos primeiros sintomas e, na maior parte dos casos, inicia-se pelos membros superiores, mãos e braços, geralmente iniciando-se de um lado. 
Esses membros tendem a ficar mais finos devido à perda progressiva da massa muscular. Na progressão da doença, há o surgimento de cãibras, reflexos involuntários e rigidez muscular. Nos estágios mais avançados há alteração de fala, diminuição de volume da voz, tosse por facilidade em engasgar com os alimentos. A fase final da doença é caracterizada por imobilidade, disfagia, insuficiência respiratória e, muitas vezes, comunicação restrita a um código obtido com comunicação dos olhos. A partir do diagnóstico, na forma clássica, o óbito se dá em torno de três anos por insuficiência na musculatura respiratória. A ELA não afeta a capacidade de raciocínio, pois os neurônios atingidos são os motores e o paciente mantêm-se consciente até o fim.

Apesar de não haver cura da ELA no momento, pode-se melhorar a sobrevida e a qualidade de vida, com medicações e a intervenção da equipe multidisciplinar; médicos, fisioterapeutas, fonodiólogos, enfermagem, psicólogos, assistente social, nutricionista, terapeutas ocupacional.

Em nossa experiência clínica, pudemos observar que os pacientes portadores de ELA e seus familiares, quando chegam ao ambulatório da Neuromuscular, vêm com diferentes diagnósticos de vários médicos. Geralmente, fizeram peregrinação por vários consultórios e hospitais. São com estes pacientes e familiares fragilizados, assustados e com uma doença grave, sem prognóstico de cura, que os profissionais do Ambulatório de ELA vão lidar.

\section{I.2. A RELAÇÃo PACIENTE - PROFISSIONAL DE SAÚdE 1.2.1.PROCESSO DE ADOECER E A NOÇÃO DE SOFRIMENTO}

Quando falamos de dor e sofrimento tomamos como base o conceito de sofrimento humano de Barus Michel (2001). Segundo a autora, há uma distinção entre sofrimento e dor: sofrimento está relacionado à dimensão moral, e dor à dimensão física, ao orgânico propriamente dito. Neste sentido, sofrimento reflete sentimentos de aflições, pesar, luto, tristeza, angústia, em um grau mais ou menos intenso, com certa duração, ligada a uma representação difícil ou impossível de suportar. Mesmo sendo obscuro, indefinido ou até ignorado, supõe-se sempre que o sofrimento tenha uma causa, esteja ligado a uma experiência, a um acontecimento 
que feriu, abalando o equilíbrio psíquico. $\mathrm{O}$ sofrimento afeta o sujeito e sua subjetividade, sua unidade e integridade, sua coesão e coerência.

Kaës (1987) analisa que o sofrimento surge assim que nossas capacidades de manter a continuidade e a integridade de nosso eu tornam-se deficitárias.

Barus - Michel (2001) compreende doença como sendo uma ruptura da estabilidade psíquica refletindo sentimentos que muitas vezes equivalem à dor física. Geralmente o sofrimento psíquico e a dor física sobrepõem - se uma à outra. $\mathrm{O}$ sofrimento, segundo a autora, também é um excesso emocional que acompanha uma interrupção do sentido ou uma representação difícil de compreender. A reinscrição em um contexto significativo permite assimilar novamente o sofrimento e mesmo destituí-lo, devolvendo os investimentos que ele drenou ao serviço de uma dinâmica viva e coerente. $\mathrm{O}$ sujeito recupera-se mais ou menos de acordo com o grau de interiorização e adesão.

Botega (2002) reafirma que o surgimento de uma doença, seja ela aguda ou crônica, transforma-se num fator de ruptura no que diz respeito à integridade psico social do indivíduo, na medida em que este sente-se impedido e limitado para dar prosseguimento à sua vida, deixando de ser dono de si próprio, tornando-se escravo de suas limitações, do seu corpo e de seu tempo. A doença sinaliza a mortalidade do ser humano, a finitude do corpo e a percepção de não ter mais controle do físico e da vida. O processo do adoecer, de perdas físicas, sociais e psicológicas é gerador de grande sofrimento psíquico.

O declínio das funções básicas para a realização das funções diárias, a perda da autonomia, as perdas sociais e afetivas, a dependência da família, da "sorte" e dos profissionais envolvidos em seu tratamento levam o paciente a um quadro de estresse emocional. (Jeammet 1982; Maciel 2000).

Desde modo, o processo do adoecer é em si estressante para o paciente, na medida em que a doença desorganiza sua vida em todos os aspectos implicando em uma demanda que muitas vezes excede os recursos internos e externos para enfrentála. O paciente vivencia sua doença como sendo uma ameaça à sua própria vida, aos medos em relação à morte, à perda de sua integridade física e psicológica. (Santos e Sebatiani, 1996). 
Casarini (1997) reafirma a questão do quão estressante é o processo de adoecimento e o modo pelo qual o indivíduo age e reage frente a ameaça à sua integridade física; o medo da perda de controle de seu corpo e de sua vida. O medo da dor frente a estas situações estressantes e medo da morte são denominados de enfrentamento. $\mathrm{O}$ resultado do enfrentamento destas muitas variáveis do processo do adoecer é o ajustamento psicossocial (ou não) e um nível satisfatório (ou não) de qualidade de vida.

Dentro de nossa cultura, geralmente quando o indivíduo adoece, passa a ser tratado não como sujeito, mas sim como o portador de uma determinada patologia. $\mathrm{O}$ estereótipo de doente e paciente é definido como alguém incapaz de gerenciar sua própria vida e seu significado está tão introjetado na nossa cultura que o indivíduo acometido de alguma doença vê-se com necessidades de reformular até mesmo seus valores e conceitos de homem, mundo e relação interpessoal em suas formas conhecidas. ( Camon, 1998).

A doença e o processo do adoecer carregam em si um significado próprio para cada indivíduo, ou seja, a forma como cada pessoa adoece está diretamente relacionada ao modo como organizou seu curso de vida, levando-se em consideração aspectos de ordem biológica, psicológica, social e cultural presentes no seu viver; diferenças genéticas de cada indivíduo; interações entre fatores genéticos e ambientais; características de personalidade; relacionamentos afetivos e vínculos familiares entre outros fatores. (Zimerman,2000).

Botega (2002) compartilha esta idéia afirmando que o adoecer está relacionado com a história de vida do indivíduo e que, para entender sua ressonância psicossocial, é necessário entender o significado emocional do adoecimento para o indivíduo, em particular dentro de seu universo pessoal. A maneira como cada indivíduo reage a uma doença está relacionada a inúmeras variáveis tais como: crenças pessoais, estado emocional, história de vida, características da personalidade, organização de capacidades defensivas, capacidade de tolerar as frustrações e outros muitos fatores.

Assim sendo, a doença é revestida de significados e sentimentos próprios e únicos de cada indivíduo, os quais interferem e determinam seu curso e vão 
interferir de modo significante na tomada de decisões, na adesão ao tratamento podendo facilitar ou dificultar o processo terapêutico. (Romano, 1999).

O autor analisa que o processo do adoecer não se limita só ao paciente mas também ao grupo familiar ao qual pertence. Deste modo, para entender o processo de adoecimento de um indivíduo é necessário estender esta compreensão para o grupo familiar, o modo pelo qual o paciente se insere no grupo e como lida com todo este processo.

Assim como a doença representa uma ruptura para a estabilidade psíquica do paciente, esta quebra também se estende ao grupo familiar, exigindo transformações nos papéis familiares e leis que regulavam seu funcionamento. A família pode ser compreendida como contexto-problema ou como recurso terapêutico que auxilia o paciente em seu processo de adoecimento e sofrimento. (Jeammet, 1982).

\subsubsection{A DOENÇA E OS PROFISSIONAIS DE SAÚDE}

Na compreensão do processo de adoecimento, também faz - se necessário ampliar esta análise aos profissionais de saúde que cuidam diretamente destes pacientes fragilizados e em estado de sofrimento.

Em nosso trabalho, iremos mencionar, em vários momentos, o profissional médico, seu papel, seu estereótipo, sua relação com o paciente, acreditando também ser possível estender a análise deste a outros profissionais da área da saúde, levando em conta as diferenças próprias de cada profissão. Esta extensão é feita pois, em nosso levantamento bibliográfico e na maioria dos trabalhos encontrados, somente a figura do médico é mencionada, ou seja, foram poucos os textos encontrados que abrangessem outros profissionais da área da saúde, apesar de estes terem o mesmo objeto de trabalho - o paciente. O médico ainda é colocado no centro em relação à equipe de profissionais de saúde, ao paciente, tratamento e familiares. ( Rocco,1992;Jeammet,1982; Esslinger,2003).

Sancovski (2002) entende esta questão analisando o estereótipo do médico como sendo aquele que atende a uma expectativa da sociedade à qual ele está inserido, ou seja, ainda está fortemente relacionado como o profissional que retém o poder da cura, de salvar vidas e de poder "driblar" a morte. 
O contato com a doença e com a morte faz do trabalho da equipe de saúde uma tarefa altamente ansiogênica, podendo desencadear respostas defensivas por parte dos profissionais e, assim, influenciar o tratamento do paciente. (Bleger, 1984).

Segundo Balint (1975) a relação profissional-paciente é uma relação desigual, na medida em que o paciente busca um saber específico do qual não dispõe, espera a cura ou o alívio dos sintomas, procurando ajuda e proteção. $\mathrm{O}$ paciente frente a esta demanda coloca-se em posição de fragilidade e passividade frente ao profissional. Por sua vez, o profissional é levado a exercer o papel protetor solicitado pelo paciente e familiares, sendo colocado em um papel onipotente e reparador. O profissional tem expectativas de reconhecimento por parte de seu paciente.

Frente a estas questões, Caprara (2004), analisa as diferenças de concepções do fenômeno saúde e doença devido aos diferentes conhecimentos adquiridos e das singularidades culturais presentes nos pacientes e profissionais. Os profissionais detêm o conhecimento científico e o paciente é excluído deste conhecimento transformando a relação profissional - paciente numa relação assimétrica,

Os profissionais de saúde, envolvidos em sua rotina de trabalho, muitas vezes não se dão conta do sofrimento mental e suas conseqüências produzidas pelo contato constante com a doença e com a morte. Estas variações nos profissionais de saúde podem influenciar positivamente ou negativamente no lidar com o paciente e sua família, com o tratamento que lhe é oferecido, além de influenciar nas relações intergrupais. (Balint, 1975).

Campos (2005) analisa que, muitas vezes, o processo do adoecer implica em si alterações profundas no psiquismo do indivíduo, como também na dinâmica familiar. Os sinais e sintomas próprios do adoecer tais como possíveis deformidades, vômitos, mau cheiro que, implicam em intervenções muitas vezes invasivas como curativos, sondagens, amputações e outros procedimentos, fazem com que os profissionais de saúde sejam colocados em papéis além da possibilidade humana de alcançá-los.

Esslinger (2003) ressalta quanto os profissionais de saúde, que lidam com pacientes em estágio avançados de doenças, não estão capacitados, em termos psicológicos, para lidar com suas próprias angústias e a dos pacientes, trazidas pelo processo da morte. Esta limitação está relacionada a questões culturais, de formação 
profissional e falha no suporte emocional. A autora destaca a solidão vivenciada pela equipe de saúde diante de seus próprios medos e angústias, sentimentos de despreparo para lidar com a morte e com o morrer. Conclui seu estudo apontando para a necessidade de haver um suporte emocional para os profissionais em contato direto com a morte, sofrimento e dor.

Kovács (2003) desenvolve a idéia de que os profissionais de saúde, principalmente aqueles que lidam com uma excessiva carga de sofrimento, muitas vezes não têm a possibilidade de lidar com sua própria dor, de elaborar o luto e que esta indisponibilidade levará ao adoecimento do profissional. Afirma que,

"A diferença básica entre as pessoas em geral e os profissionais da área de saúde, médicos, enfermeiras e psicólogos, é que na vida destes a morte faz parte do cotidiano $e$ pode se tornar sua companheira de trabalho diária. Toda doença é uma ameaça á vida e, portanto, pode aparecer como um aceno à morte” (p.23).

Temos uma compreensão de que o trabalho dos profissionais de saúde gera ou pode gerar sofrimento, e que estes também necessitam de um holding, tanto quanto o pacientes. "São pessoas singulares, com desejos e necessidades e, em razão dessa sua natureza humana, precisa ser conhecido e compreendido.”( Bellodi, 2007,p27).

Winnicott (1994) desenvolveu o conceito de holding, o qual tem como significado cuidar, ser continente, acolher. Assim como os profissionais de saúde cuidam de seus pacientes, estes também necessitam ser cuidados.

Martins - Nogueira (2006) enfoca a preocupação em estudar a saúde mental dos profissionais da área de saúde, especialmente em relação aos médicos e enfermeiros, na medida em que é conhecida a alta prevalência de distúrbios emocionais nestes profissionais. 
$\mathrm{O}$ autor ressalta que

\begin{abstract}
"Diversos campos do conhecimento têm oferecido importantes contribuições para a compreensão dos fenômenos ligados ao sofrimento psíquico, ao estresse ocupacional e ã saúde mental dos profissionais da área da saúde. Da fisiologia vieram os conceitos de estresse e síndrome geral de adaptação; da psicanálise, as noções de inconsciente dinâmico, conflito psíquico, ansiedade e mecanismos de defesa do ego; e, mais recentemente, da área de administração de recursos humanos, o modelo conceitual de demandacontrole”.(p.145).
\end{abstract}

Um aspecto importante na atuação do profissional de saúde diz respeito à longa jornada de trabalho, à pobre remuneração e outras dificuldades que podem surgir. Severo (1993) referiu-se especialmente ao psicólogo, e ao mesmo tempo, para esse autor, é esse o profissional que tem, pela sua própria formação, capacidade de relacionamento e aceitação.

Dessa forma, nessa pesquisa discutimos sentimentos e ansiedades decorrentes desta situação. Esses conceitos são definidos de forma muito variável em psicologia, segundo a linha teórica adotada. E, mesmo na mesma abordagem, pode haver distintas definições.

Assim podemos falar de frustrações, uma vez que atender a pacientes sem prognóstico de cura pode trazer esse tipo de reação. Entendemos assim frustração, segundo a definição de Lagache, (1966) "como a condição de um organismo que encontra um obstáculo, mais ou menos intransponível, interno ou externo, à satisfação de uma necessidade ou desejo.” (p.193).

Tardivo (1997) ao apresentar referenciais de análise para distintos instrumentos projetivos apóia-se na abordagem kleiniana e assim define sentimentos presentes. A autora denominou de Sentimentos Derivados do Instinto de Vida, aqueles de tipo construtivo: alegria, amor, energia instintiva e sexual; Sentimentos 
Derivados do Instinto de Morte, os destrutivos como ódio, raiva, inveja, etc. E Sentimentos Derivados do Conflito, sentimentos ambivalentes, que surgem da luta entre os Instintos de Vida e de Morte; ou seja, sentimentos de culpa, medos de perda, de abandono, sentimentos de solidão, de tristeza, de desproteção e outros.

Ainda seguindo a mesma linha teórica, Tardivo (idem) apóia-se nas definições de ansiedade de M. Klein (1982), e considera existirem dois tipos básicos de ansiedade: as paranóides, mas primitivas ligadas à posição esquizo-paranóide e as depressivas, que são mais evoluídas e decorrentes da elaboração da denominada posição depressiva.

Pode-se ainda destacar o sentido de ansiedade empregado em psicopatologia e definido nos manuais (DSM IV e CID 10) como básico nos chamados Transtornos de Ansiedade, como alterações que, segundo a abordagem psicanalítica, estariam mais próximas das neuroses (Gabbard,1998)

Campos (2005) preocupa-se com as questões referentes ao suporte social como meio de preservar a integridade física e psicológica dos profissionais da área de saúde. Define suporte social como sendo aquele que estabelece vínculos interpessoais, grupais ou comunitários próximos às pessoas envolvidas proporcionando sentimentos de apoio e de proteção.

\subsection{A ENFERMIDADE E OS MECANISMOS DE DEFESAS}

A partir das considerações às quais vimos nos referindo, podemos observar que tanto os pacientes, especialmente aqueles portadores de doenças graves, crônicas e aquelas sem prognóstico de cura, bem como os profissionais de saúde que lidam com estes pacientes, estão expostos constantemente à dor e ao sofrimento que pode levar a um processo de desestabilização não só física como também psíquica, tendo nos mecanismos de defesas o meio de restabelecer o equilíbrio. (Bellodi, 2006).

Freud no texto sobre As Neuroses de Defesa (1894) começa a desenvolver o conceito de defesa, adquirindo seu sentido mais preciso em 1926 em Inibições, Sintomas e Ansiedade, como sendo um conjunto de operações efetuadas pelo Ego perante os perigos que procedem do Id, do Superego e da realidade exterior. Podemos entender que o Ego em si mesmo é uma defesa perante os perigos internos 
e externos e que o acionamento dos mecanismos de defesas são automáticos e inconscientes. (Kusnetzoff, 1982).

Kusnetzoff (1982) afirma que o "sujeito consciente sofre a ação tanto do perigo como dos afetos desencadeados que causam desprazer(angústia),bem como do conjunto de operações defensivas mobilizadas pela parte inconsciente do Ego ' (p.206) e conclui situando os mecanismos de defesas como meios essenciais e importantes de estabilizar o aparelho psíquico visando uma função homeostática,

Anna Freud, em sua obra O Ego e os Mecanismos de Defesa, ampliou (1936/2006) o trabalho de Freud acrescentando e desenvolvendo outros mecanismos de defesa: regressão, formação reativa, anulação, introjeção, identificação, projeção, voltar-se contra si próprio, reversão e sublimação, ressaltando que estes são instrumentos fundamentais e essenciais na intervenção do ajustamento, adaptação e equilíbrio da personalidade.

Para Gabbard (1998), os mecanismos de defesa mais presentes são os de repressão, deslocamento, formação reativa, isolamento do afeto, anulação, somatização e conversão.

Rocco (1992), sobre os mecanismos de defesa afirma que “... as experiências individuais do adoecer põem em jogo mecanismos inconscientes de adaptação e defesa, de regressão, negação e racionalização principalmente"(p.46).

Bellodi (2001) menciona a regressão como mecanismo de defesa comum de ser observado nos pacientes na medida em que eles vão se fragilizando com o adoecer. A negação e a racionalização também estão presentes na maioria dos casos como forma de dar conta do sofrimento ocasionado pelo processo do adoecimento. Tem sido interessante observar, em nossa experiência clínica que, mesmo tendo em comum os mesmos mecanismos de defesa para dar suporte ao sofrimento, cada paciente vai vivenciar o processo do adoecer de modo diferenciado.

Para Spitz (1997) , o adoecer diferencia-se em cada indivíduo na medida em que os mecanismos de defesas acionados estão diretamente relacionados à personalidade, ao processo de vida, à história especifica de cada um.

Os mecanismos de defesa surgem como forma de adaptação e reação, mesmo que inadequada, como forma de lidar com os conflitos emocionais desencadeados 
pela doença. Os mais conhecidos são o de negação, deslocamento, regressão, adaptação entre outros. (Botega, 2002).

O autor (idem) define o mecanismo de negação quando o paciente age como se não estivesse doente tentando enganar a si mesmo e aos outros, adotando uma atitude negativa de não aceitar os cuidados da equipe profissional. $O$ uso inconsciente deste mecanismo é usado como meio de evitar o sofrimento, o medo a angústia trazido pela doença, refletindo o quanto o indivíduo encontra-se fragilizado e amedrontado com seu adoecer. Nesse momento, o mecanismo de negação tem como significado o de proteção e deve ser compreendida pela equipe de saúde,na maneira de lidar com este paciente .

Kubler - Ross (1987) aponta o mecanismo de defesa de negação como importante recurso psíquico que o paciente encontra para lidar com sua angústia e medo frente à doença. No momento em que o paciente recebe o diagnóstico, a negação faz-se presente; o paciente considera que houve erro na avaliação médica, nos exames e na conduta da equipe de saúde. A autora ressalta o quanto é importante a equipe de saúde compreender este momento interno do paciente, para poder estabelecer relações interpessoais adequadas.

Botega (2002) menciona outro mecanismo de defesa muito usual nos pacientes, o de deslocamento. A raiva, ressentimentos e inveja desencadeados pela condição de estar doente normalmente são conseqüência de uma negação anterior. Este mecanismo serve para o paciente evitar uma situação depressiva, de desespero maior. Ele tende a deslocar sua raiva contra família e equipe de saúde, culpando-as por sua doença. O paciente muitas vezes tem atitudes agressivas, de arrogância e desprezo. Muitas vezes exige um nível de atenção que se torna extremamente desgastante para todos que cuidam dele. Estas atitudes, segundo o autor, podem ter uma repercussão negativa na equipe, como forma de se defender da carga de agressividade e hostilidade vindas do paciente.

Kluber - Ross (1987) ressalta o quanto que é importante a equipe ter consciência deste momento psíquico do paciente de maneira a ele ser melhor compreendido, aceito e cuidado.

Botega (2002), ao eleger os principais e mais presentes mecanismos de defesas desenvolvidos pelos pacientes, define um deles - a regressão, como também 
bastante freqüente. O indivíduo protege-se de uma agressão, sofrimento que é provocado pelo adoecimento. A regressão é marcada por um retorno do paciente às formas anteriores de desenvolvimento do pensamento e de sua relação com o ambiente e com as pessoas. Normalmente, o indivíduo adota uma conduta infantil frente a sua doença, colocando-se numa situação de dependência e de necessidade de atenção em relação aos outros.

Para Jeammet (1982), o mecanismo de regressão caracteriza-se por uma redução de interesses, pouca tolerância às frustrações, pensamento mágico e onipotente e extrema dependência em relação aos familiares e a equipe que o está tratando.A regressão pode se tornar positiva quando o paciente tem disponibilidade psíquica de aceitar ser cuidado pela equipe médica e familiares.

A aceitação ou adaptação é outro mecanismo de defesa, e ocorre quando o paciente consegue elaborar o seu adoecer e, a partir da percepção de como se encontra, procura recursos internos para se organizar frente a este novo momento de vida.( Kluber - Ross ( 1987 ).

A autora (idem) descreve estes mecanismos como um processo seqüencial no processo do adoecer, os quais não precisam necessariamente seguir esta ordem. Ela enfatiza que o modo pelo qual cada paciente vai vivenciar a negação, deslocamento, regressão e aceitação vai depender da história de vida de cada um, pois o adoecer está diretamente relacionado ao modo pelo qual o indivíduo concebeu o seu viver.

Ao descrever os mecanismos de defesa que vão surgindo no processo do adoecer, como forma de dar conta do sofrimento, dor e angústia, os profissionais de saúde que cuidam destes pacientes também interagem com essas demandas mobilizando suas defesas para conseguirem lidar com a situação que estão vivenciando. Sendo assim, tanto os pacientes como os profissionais utilizam-se dos mecanismos de defesa para sua adaptação e reação frente à condição de se estar em contato direto com o sofrimento e desestabilização do psiquismo. 


\subsection{A RELAÇÃo PROfissional de SAÚde - PACIENTE TRANSFERÊNCIA E CONTRATRANSFERÊNCIA}

Michael Balint ao estudar a relação médico - paciente sob o ponto de vista psicológico, influenciou profundamente não só médicos, mas profissionais de saúde de modo geral a refletirem suas práticas, objetivando uma compreensão mais humanizada do adoecer humano. Seus estudos foram a base da Psicologia Médica, além de terem grande influência em trabalhos na área psicossomática. (Kovács, 2003).

Balint (2005) concentrou seus interesses em compreender os pacientes que iam ao seu consultório para além de suas queixas sobre suas doenças. Para ele, cada doente possuía sua própria história e, como tal, suas queixas só poderiam ser entendidas se o médico estivesse atento para ouvir e perceber as demandas inconscientes que os pacientes traziam para as consultas. As respostas dos médicos para este paciente poderiam ter um efeito terapêutico complementar ao tratamento médico tradicional. Sua famosa e conhecida frase "O remédio mais usado em Medicina é o próprio médico, o qual, como os demais medicamentos, precisam ser conhecidos em sua posologia, relações colaterais e toxidade" enfatiza a necessidade de mudanças profundas na relação médico-paciente. Para Balint, a qualidade da relação com o paciente é determinante para que este se vincule, ou não, ao tratamento.

O autor compreendia esta postura mais sensível do médico em relação ao paciente como sendo responsável pelo que chamava de fenômeno transferencial. Para Balint, esta mudança de postura frente ao paciente faz com que a doença deixe de ser o eixo principal, e que a historia de vida do paciente, com suas próprias vivências, aquilo que o distingue de todos os outros, tornando-o único, inclusive no seu adoecer, ocupe o seu devido lugar.

Laplanche (1970) define transferência em psicanálise, como sendo: 
"o processo pelo quais os desejos inconscientes se atualizam sobre determinados objetos, no quadro de certo tipo de relação estabelecida com eles e, eminentemente, no quadro da relação analítica. Trata-se aqui de uma repetição de protótipos infantis vivida com uma sensação de atualidade acentuada.” ( $p$. 668/669).

Jeammet (1982), a partir da definição de transferência em que o indivíduo repete nos relacionamentos atuais, padrões das relações primárias vividas no passado, desloca esta definição para a relação do profissional com o paciente ao afirmar que, no processo de transferência o profissional, surgem sentimentos afetuosos, hostis e outros que não são justificados pela relação atual. Deste modo, a vida emocional do paciente é revivida na transferência, adquirindo sentido na realidade psíquica do mesmo, mas não na relação atual com o profissional. Este acaba servindo de modelo para questões que não dizem respeito a ele e nem à relação que está sendo estabelecida entre ambos.

$\mathrm{O}$ autor (idem ) prossegue afirmando que o paciente tem uma tendência a depositar no profissional uma série de sentimentos e de imagens pré - estabelecidas por meio de uma relação transferencial. O profissional acaba sendo depositário de vários papéis, tais como de pai autoritário ou não, mãe ausente ou protetora, e outros. Conclui afirmando que o paciente pode ser colaborativo ou não, dependendo dos papéis e afetos que foram transferidos para o profissional. Assim, diz ele, a relação transferencial pode ser positiva ou negativa. A relação de transferência pode ser positiva quando o paciente transfere para os profissionais sentimentos de afeto, reconhecimento, gratidão e outros, ou negativa quando o profissional é investido de desconfiança, inveja, desprezo e outros.

Segundo Zimerman (1992), do mesmo modo que pode existir a transferência na relação médica - paciente, é também importante considerar que os médicos não são destituídos de afetos, sentimentos e estes diferem em relação a diferentes pacientes. A transferência e contratransferência são simultâneas e interativas, 
caracterizando o vinculo estabelecido entre o médico e seu paciente. Segundo ele, os aspectos da personalidade do médico podem influenciar o vínculo estabelecido com o paciente, dizendo que estas características de personalidade, somadas aos conhecimentos e habilidades médicas, irão definir seu modelo de atendimento. Este modelo é que irá definir a relação médico-paciente como sendo uma relação recíproca em que atuam a transferência e a contratransferência.

Consideramos importante salientar que o termo contratransferência foi usado pela primeira vez por Freud no artigo "As perspectivas futuras da terapia psicanalítica" (1910/1996). Freud refere-se à resposta emocional do analista aos estímulos que provêm do paciente como resultado da influência do analisado sobre os sentimentos inconscientes do médico.

Para Jeamet ( 1982 ) não existe neutralidade na relação profissional de saúde paciente, pois o relacionamento de ambos está permeado de sentimentos, experiências e expectativas também por parte dos profissionais, do tipo; bom paciente, mau paciente, o paciente colabora, e outros papéis, pois também por parte do profissional há todo um contexto psíquico do mesmo modo que há no paciente.

Spitz (1997) reforça este pensamento da relação médico-paciente afirmando que,

"Na prática, é absolutamente impossível falar em reações dos pacientes sem imediatamente nos remetermos ao parceiro do paciente quando ele enfrenta a sua doença: o médico, ou seja: o médico também apresenta reações psicológicas à doença do paciente.” (p. 91).

Da mesma maneira que a transferência pode ser positiva ou negativa, a contratransferência também pode ser positiva ou negativa.

Balint, Winnicott e outros contemporâneos, revêem o conceito de contratransferência como instrumento útil na relação médico-paciente. Winnicot considera positiva a contratransferência desde que o profissional conheça seus próprios sentimentos para que consiga compreender aspectos psíquicos importantes de seu paciente, intervindo de forma e no tempo adequado. (FIGUEIRA, 1994). 
Bellodi (2001) conclui estes importantes conceitos de transferência e contra transferência afirmando que;

“... o paciente repete com o médico, no presente, atitudes, fantasias $e$ desejos antigos $e$ inconscientes. $\quad \dot{E}$ o chamado fenômeno transferencial, ou seja, o deslocamento de elementos do passado para um presente novo $e$ diferente. O médico, por sua vez, alvo desse movimento, não permanece imune e reage ao ser deslocado nesse outro lugar pelo paciente. Esse fenômeno chamado de contratransferência é também uma resposta não consciente". (p.26)

\subsection{O CONCEITO DE QUALIDADE DE VIDA E O CONTATO COM AS ENFERMIDADES}

Acreditamos que, para ampliar nossa compreensão sobre as relações estabelecidas entre os profissionais de saúde com os pacientes portadores de ELA, faz-se necessário acrescentarmos a este trabalho o estudo sobre Qualidade de Vida, para que seja possível melhor avaliarmos como o profissional está interagindo e reagindo, em seu contexto de trabalho e de vida.

O conceito de qualidade de vida tem suscitado muitas pesquisas e sua utilização tem sido cada vez maior por parte dos profissionais de saúde junto a pacientes com doenças crônicas, degenerativas e terminais, geralmente em contextos hospitalares. A utilização dos questionários de Qualidade de Vida em geral têm sido utilizados pelos profissionais para redimensionar os serviços de atendimento e hospitalares.

De acordo com a Organização mundial de Saúde (OMS), a Qualidade de Vida pode ser definida como "a percepção do indivíduo de sua posição de vida, no contexto da cultura e sistemas que traduza valores nos quais vive e, em relação aos seus objetivos, expectativas, padrões e preocupações". 
O termo Qualidade de Vida Relacionada à Saúde - QVRS (Health-Related Quality of Life - HRQOL) é um subconjunto do termo mais amplo e recebe essa especificação por incluir os domínios físico, psicológico e social relacionados à saúde.(Duarte e Ciconelli, 2006,p11).

Seide e Zannom (2004), no artigo "Qualidade de Vida e Saúde: Aspectos conceituais e metodológicos” enfatizam os questionários de Qualidade de Vida como instrumentos importantes de avaliação dos serviços de saúde, tendo como referencial o paciente, levando-se em conta o impacto físico e psicossocial que as doenças podem acarretar, permitindo um melhor conhecimento do paciente e de sua adaptação à condição de doente. Nesses casos, a compreensão sobre a QV do paciente incorpora-se ao trabalho do dia-a-dia dos serviços, influenciando decisões e condutas terapêuticas das equipes de saúde.

As autoras definem o conceito de Qualidade de Vida de duas maneiras, ou seja, quando relacionado à saúde propriamente dita e de modo mais genérico. Os questionários de Qualidade de Vida relacionados às questões de saúde têm como objetivo básico ser um instrumento de intervenção para a melhoria dos serviços de saúde para pessoas que estão com algum tipo de enfermidade.

Os questionários de Qualidade de Vida que não estão relacionados diretamente aos serviços de saúde e a enfermidades e, sim, a um conceito mais genérico, têm como função verificar o momento atual que a pessoa está vivendo e o modo pelo qual está lidando com algumas situações que diz respeito ao seu físico e aos seus afetos, sob esta perspectiva que utilizaremos o questionário Qualidade de Vida.

Vale destacar que as maiorias dos estudos feitos enfocam a qualidade de vida dos pacientes. Neste estudo, nosso interesse residiu na respostas dos profissionais de saúde, sendo esse também um dos aspectos inédito do estudo.

Dessa forma, utilizamos o Questionário de Qualidade de Vida de McGill, na versão em português de Silva, Tardivo e Callegaro (referência eletrônica 1995/1997).( ANEXO 5 ).

O emprego desse instrumento pode também trazer contribuições nesse estudo, em função de nossos objetivos. 


\section{CAPÍTULO II - JUSTIFICATIVA E OBJETIVOS}

Vimos pela Introdução deste trabalho, o quanto a Esclerose Lateral Amiotrófica demanda extremo sofrimento psíquico, não só para os pacientes que se vêem incapacitados, perdendo suas funções motoras gradativamente, sem perder a lucidez, como também para todos os que convivem com este paciente.

O projeto Tutor tem nos permitido observar que geralmente, os que estão envolvidos com a ELA, revelam sintomas de estresse, ansiedade, depressão e desesperança, mas revelando ao mesmo tempo disponibilidade e empenho em cuidar.

Também tivemos oportunidade de observar, os profissionais de saúde que trabalham no atendimento aos pacientes com ELA, através das reuniões mensais administrativas e técnicas do Ambulatório, de simpósios, encontros e, pudemos constatar o quanto o grupo se dedica a estes atendimentos e a carga afetiva a que estes profissionais estão submetidos constantemente.

A equipe, muitas vezes demonstrou interesse em discutir conosco questões referentes aos atendimentos e aos relacionamentos com os pacientes reforçando a necessidade que a equipe tem de se conhecer melhor enquanto grupo.

A partir deste enquadre, estruturamos o presente trabalho como forma de ampliar os nossos conhecimentos e acreditar que os resultados obtidos possam contribuir para uma reflexão entre a equipe de saúde.

Além disto, verificamos que a bibliografia que consultamos para a realização deste trabalho referia-se em grande parte na análise das relações entre médico e paciente, sendo poucos os trabalhos referentes a outros profissionais da área de saúde, e nada equivalente ao estudo da relação dos profissionais de saúde com pacientes portadores de ELA. Este dado foi mais um incentivo para que esta pesquisa fosse realizada e temos clareza que este trabalho será um estímulo para darmos continuidade a este tema.

Portanto, mediante estas considerações, o objetivo geral do presente trabalho é compreender os aspectos afetivos e emocionais dos profissionais de saúde na relação com os pacientes portadores de ELA e seus respectivos cuidadores. 
Pormenorizando os objetivos desse estudo, podemos descrever como específicos a serem contemplados, a partir de cada um dos instrumentos a que se segue:

Pelas entrevistas,

- determinar o perfil sócio - demográfico do grupo de profissionais

-. determinar a identificação profissional do grupo

-. inter-relacionar as variáveis sócio-demográficas de identificação pessoal com a funcional

- analisar diversos sentimentos que surgem em situações de atendimento

Pela análise dos índices escolhidos do Rorschach,

- compreender o tipo de percepção que o grupo possui em relação ao meio, no caso, o trabalho.

.- identificar a dinâmica afetiva do grupo através das respostas de cor, de movimento, respostas de conteúdo animal.

- relacionar o índice de afetividade com o índice de impulsividade

- levantar os tipos vivenciais do grupo ( Eq )

- relacionar o equilíbrio das forças subjetivas

Pelo questionário de Qualidade de Vida da McGill

- analisar como os profissionais se encontram em seus diversos aspectos em termos de suas qualidades de vida numa escala de 0 a 10.

Temos claro que, as análises destes dados, possibilitaram compreender como estas variáveis vão interferir na relação com os pacientes e como, os pacientes vão responder a estas demandas dos profissionais de saúde. 


\section{CAPÍTULO III - MÉTODO}

\subsection{TIPO DE MÉTODO}

O método empregado neste estudo foi o clínico, escolhido em função de ser muito indicado em psicologia clínica, pois como coloca Bleger (1984), a investigação de fatos e técnicas só se torna possível a partir do método clínico.

$\mathrm{O}$ autor afirma que,

“... dentro do método clínico guiamo-nos pela sistemática do enquadramento introduzido pela técnica psicanalítica, adaptado às necessidades deste âmbito e aos problemas que aqui temos que enfrentar" ( p.46 ).

O método clínico, segundo o mesmo autor (idem), tem como característica principal à observação que, segundo o autor, deve ser rigorosa e detalhada a partir de um enquadramento definido:

"Como o conjunto das condições nas quais se realiza a observação e constitui uma fixação de variáveis ou - dito de outra maneira - uma eliminação de parte das variáveis ou uma limitação das mesmas, ou a fixação de um conjunto de constantes, que tanto nos serve como meio de padronização como de sistema de referência do observado"( p.46).

Dando continuidade à concepção do método clínico de Bleger, Tardivo (2007) afirma que o método clínico tem como concepção a relação sujeito e meio não como uma relação linear de causa e efeito mas, sim, como uma relação dinâmica entre o indivíduo e a sociedade. Tanto o sujeito como o meio integram uma única 
estrutura. "O campo é assim considerado em sua totalidade. Faz sentido pensar que a conduta é assim uma modificação”. (p.32)

Turatto (2003) define ainda que o método clínico deve ser utilizado como meio de interpretar os significados psicológicos e sócio culturais que os indivíduos, no caso pacientes, familiares e profissionais de saúde dão ao que chama de fenômenos da saúde - doença.

A partir destas considerações, utilizamos o método clínico, o qual nos permitirá analisar os resultados de forma globalizada.Ao final buscamos um integração dos resultados obtidos realizando uma discussão e reflexão a partir de uma perspectiva psicodinâmica.

\subsection{PARTICIPANTES}

A equipe de profissionais de saúde que estava trabalhando no Ambulatório da ELA, no momento da pesquisa, era composta por vinte e três profissionais, sendo que a maioria vinculada ao Setor das Doenças Neuromusculares da UNIFESP/Escola Paulista de Medicina e alguns à ABRELA.

Todos foram convidados a participar e receberam as informações necessárias a respeito dos objetivos e procedimentos da pesquisa, bem como dos cuidados éticos indispensáveis.

A participação no presente trabalho deu-se por disponibilidade de tempo e de horário dos profissionais. Dessa forma, não participaram os que não tinham disponibilidade, tendo em vista que a demanda de pacientes do ambulatório é muito intensa e a maioria tem outros empregos.

Mesmo não participando todos os elementos do grupo, houve uma receptividade muito positiva do trabalho por todos da equipe. Muitos demonstraram interesse nos resultados do trabalho.

Os profissionais que participaram da pesquisa, foram convidados manifestando sua anuência por meio de assinatura de Termo de Consentimento. (modelo em anexo - Anexo 1 ). 
O grupo que participou da pesquisa é constituída por médicos, assistentes sociais, fisioterapeutas nutricionista e terapeuta ocupacional, representando o equivalente a 47,82\% da equipe como um todo de profissionais da área de saúde.

O local da pesquisa foi realizado no Ambulatório de Doenças Neuromusculares da Disciplina de Neurologia da UNIFESP, Universidade Federal de São Paulo, Escola Paulista de Medicina, São Paulo - CAPITAL. ${ }^{1}$

Destacamos que o projeto de pesquisa que deu origem a essa dissertação de mestrado recebeu a aprovação do Comitê de Ética de Pesquisa doa UNIFESP (Anexo - Anexo 2).

\subsection{INSTRUMENTOS E PROCEDIMENTOS}

Tendo em vista o objetivo e o método proposto, serão utilizados três instrumentos de estudo; Entrevista Psicológica Semi Estruturada, o Método de Rorschach - avaliação segundo o sistema de Aníbal Silveira, e o Questionário Qualidade de Vida McGILL.

Os instrumentos foram aplicados pela autora da pesquisa de forma individual, tendo começado pela entrevista e em seguida o Método de Rorschach, finalizando com o questionário de Qualidade de Vida a McGill.

A duração da aplicação variou segundo o ritmo de cada participante (de aproximadamente 1 hora a 2 horas).

Os instrumentos serão descritos a seguir resumidamente

${ }^{1}$ Mesmo considerando a exigência de se manter o anonimato na participação dos participantes em pesquisas com seres humanos, os profissionais concordaram com a divulgação do local onde a pesquisa foi realizada, tendo a mesma recebido a aprovação do comitê de ética , com essa informação 


\subsubsection{ENTREVISTA PSICOLÓGICA SEMI ESTRUTURADA}

Optamos por esse instrumento por ser típico do psicólogo clínico, como diz Bleger (2007) que descreve a entrevista como sendo "um instrumento fundamental do método clínico e é, portanto, uma técnica de investigação científica em psicologia" (p.1).

A entrevista psicológica procura abranger o indivíduo como um todo envolvendo a figura do entrevistador. Sendo assim, a entrevista psicológica visa atingir seus objetivos psicológicos, que são a investigação, diagnóstico, terapia e outros. Em nosso estudo não visamos esses aspectos, mas, em especial, o trabalho e as reações dos profissionais de saúde no contato com pacientes com ELA, conforme vimos apontando

Bleger ( 2007 ) dedicou-se ao estudo teórico desse fundamental instrumento do psicólogo clínico e enfatizou a grande contribuição trazida pela psicanálise ao apontar para a dimensão inconsciente do comportamento humano, da transferência e contratransferência.

O autor (idem) menciona a contribuição da teoria da Gestalt, com a compreensão da entrevista como um todo e o behaviorismo, em observar o comportamento propriamente dito.

Etchegoyen ( 2004 ) afirma que a norma básica para uma entrevista é a do entrevistador ser um facilitador no sentido de o entrevistado poder expressar livremente o que pensa e como se sente frente às situações que vão sendo colocadas.

Nesse estudo, a entrevista enfocou as reações dos profissionais diante dos pacientes com ela de forma particular.

A partir destas considerações, a opção pela entrevista semi-estruturada foi a possibilidade de se obter dados necessários para o presente trabalho, ou seja, itens que visam uma compreensão maior da dinâmica existente entre profissional de saúde e paciente, permitindo ao mesmo tempo em que o entrevistado "configure o campo da entrevista segundo sua estrutura psicológica particular, ou-dito de outra maneira - que o campo da entrevista se configure, o máximo possível, pelas variáveis que dependem da personalidade do entrevistado” (Bleger 2007, p.3). 
Elaboramos um roteiro de 25 questões, inserido em anexo (Anexo 3), sendo que as primeiras referentes à identificação pessoal; naturalidade, procedência, sexo, idade, estado civil e número de filhos.

A seguir, questões referentes à identificação profissional; formação acadêmica, quantos anos de formados, profissão, fatores que contribuíram para a escolha da profissão, como se sentem a respeito das expectativas na escolha profissional, função e tempo de atuação na ABRELA, carga horária de atendimento na ABRELA e em outros serviços. Esta parte da entrevista, concebida como semi estruturada, foi composta por questões mais diretivas,cujos dados são importantes para conhecermos o grupo que estudamos.

Finalmente inserimos questões abertas, relacionadas a situações de atendimentos em que os profissionais vivenciaram sentimentos de frustração, ansiedade, raiva, felicidade, amparo, cobrança ou tristeza.

Os dados das entrevistas foram analisados e apresentados de forma quantitativa, em porcentagem, para dar uma visão mais ampla do grupo no que diz respeito às questões mencionadas e encaradas como unidades de conteúdo e sentido.

Mesmo sendo um trabalho com base no método clínico, consideramos que a análise dos resultados de forma numérica permite o conhecimento desse grupo em particular, observando que tais dados não são generalizáveis, mostrando a forma como esses profissionais se apresentam diante da situação que estudamos.

\subsubsection{MÉTODO DE RORSCHACH - SISTEMA DE AVALIAÇÃO ANÍBAL SILVEIRA}

Escolhemos este instrumento, que é clássico e fundamental em nossa área por todas as possibilidades que o mesmo traz em estudos a respeito de aspectos afetivos emocionais, além de outros.

Empregamos o sistema de avaliação proposto por Silveira, como descreveremos mais adiante. Os índices selecionados foram aqueles relacionados ao objetivo desta pesquisa, não requerendo um estudo mais amplo, abrangente e profundo da personalidade individual que o método de Rorschach permite. 
Faremos a seguir, uma breve apresentação do método, destacando os índices que elegemos para o presente estudo.

O método foi proposto por Hermann Rorschach, nascido em Zurique, Suíça, em 1884. Em 1911, ele iniciou pesquisa com tintas, desejando obter um método de investigação da personalidade, situando a interpretação das manchas de tinta no campo da percepção e apercepção. Em 1914, especializa-se médico psiquiatra pela Universidade de Zurique. Influenciado pelo trabalho de Symon Hens, em 1917, o qual usou oito cartões com manchas não coloridas para investigar o conteúdo de respostas dadas por adultos normais e psicóticos, Rorschach cria no ano seguinte, quinze cartões - alguns com manchas pretas e cinzas, alguns com a cor vermelha e outros com manchas coloridas. Pesquisa pacientes com estas pranchas no Hospital de Herisau. Reduz para dez pranchas, por problemas de impressão, mantendo as mesmas características das anteriores, e em 1921 publica o livro Psicodiagnóstico.Vem a falecer em 1922. Alguns anos após sua morte, seu trabalho é efetivamente reconhecido na Europa e Estado Unidos. Em 1949 foi fundada a Sociedade Internacional de Rorschach. (Adrados, 1980).

O Método de Rorschach, como instrumento de investigação da personalidade em seus mais diversos aspectos, ocupa lugar de destaque entre os demais testes projetivos. É composto por dez lâminas com manchas de tinta dispostas simetricamente. As pranchas I, IV, V, VI E VII são denominadas de monocromáticas e que possuem nuances de sombreados; as pranchas II, III, VIII, IX E X são as coloridas sendo que a II e a III possuem cores monocromáticas e coloridas; e as pranchas VIII, IX E X são totalmente coloridas. São inúmeros os trabalhos, nos mais diversos temas, os quais se utilizam o Método de Rorschach, não só como psicodiagnóstico propriamente dito como também instrumento de pesquisa, tanto no âmbito nacional como internacional. Através da avaliação dos diversos indicadores do Rorschach é possível ter clara a dinâmica e estrutura da personalidade em seus mais diversos aspectos. 
Adrados (1980), afirma que:

\begin{abstract}
"A possibilidade de uma apresentação sistemática, controlada, dos dados obtidos, o fato de que as diferentes variáveis da personalidade possam ser medidas e quantificadas de forma tal que possam ser manipuladas estatisticamente e, ao mesmo tempo, o que é mais importante para o psicólogo clínico, possam informar-nos sobre a dinâmica profunda da personalidade, objeto de nosso estudo, situa este método como um dos mais utilizados com finalidade psicodiagnóstica." ( p.5).
\end{abstract}

Vaz (2001) ressalta que vários autores deram grandes contribuições, de modo decisivo, para a expansão e reconhecimento do Método de Rorschach. Estes autores, além de divulgar, ampliaram seu trabalho. Foram eles: Klopfer ( 1952), Hertz (1952), Beck ( 1961), Piotrowski ( 1957), Exner ( 1974), e outros. Estes autores acabaram desenvolvendo novos códigos e classificações as quais originaram sistemas diversos de classificação. Estas classificações foram realizadas devido às diferenças culturais de cada país, transformando o Rorschach cada vez mais em um instrumento extremamente sensível em detectar aspectos dinâmicos e estruturais da personalidade.

Destacamos que o Método também pode ser usado para investigar aspectos com as finalidades como as que temos no presente estudo.

Santos ( 2006) fez uma extensa revisão bibliográfica, na BVS-Psi, mostrando o desenvolvimento e o uso da técnica do Rorschach no Brasil, tendo encontrado muitos desses estudos em nosso meio.

A Sociedade Rorschach de São Paulo está associada ao nome do renomado psiquiatra e psicólogo Aníbal Silveira, fundador da mesma a 24 de julho de 1952, com os objetivos específicos de ensinar o Psicodiagnóstico de Rorschach, de discussão científica da interpretação de protocolos e de aspectos relacionados à interpretação dos mesmos. Naquela ocasião, apenas alguns psiquiatras ou professores 
universitários haviam estudado o método de Rorschach, após sua aprendizagem nos Estados Unidos ou na Europa.

Há vários sistemas de análise do Método de Rorschach, porém, todos eles tem como base a percepção e apercepção. Coelho (1980) afirma que

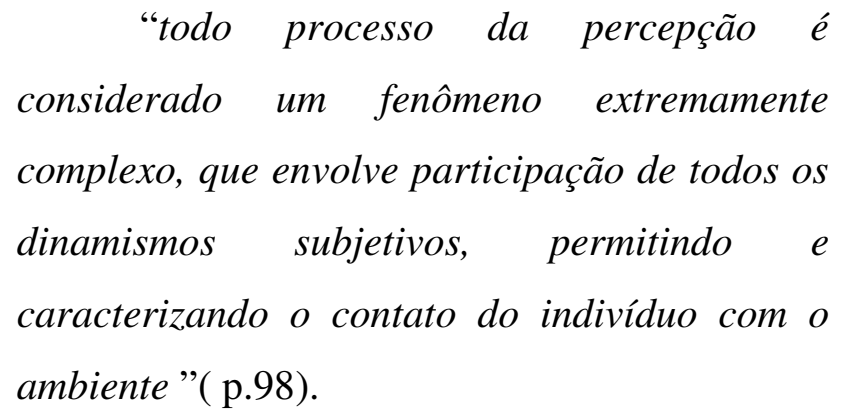

Em continuidade, a autora define as imagens obtidas através das pranchas de Rorschach como sendo resultantes da dinâmica psíquica do examinando e que as mesmas ocorrem através das funções intelectuais de observação concreta e abstrata. As seleções dos aspectos encontrados na pranchas estão diretamente relacionadas com a função conativa, convergência de atenção e as de interesse afetivo. Coelho conclui afirmando que

"A noção obtida a partir dessa imagem vem
impregnada de reações afetivas que
permanecem em parte em nível inconsciente
(componente acessório da imagem), ao passo
que o componente principal já é isolado através
da associação consciente para o
estabelecimento do nexo intelectual" (Silveira,
p.109).

Silveira (1985), afirma ser o Rorschach instrumento privilegiado para acesso às principais funções psíquicas, definidas por ele como conativas afetivas e intelectuais.

Coelho (1980), prosseguindo o trabalho de Aníbal, situa os conceitos básicos em relação às principais funções psíquicas por ele consideradas, a saber, afetivas, 
conativas e de inteligência as quais vão permear toda a análise dos dados e variáveis do teste de Rorschach. Segundo Silveira, estas três funções básicas são resultantes do funcionamento cerebral em sintonia com o meio físico e social, afirmando que,

"O indivíduo toma contato com o meio externo, evidentemente porque o cérebro está funcionado, mas os processos psíquicos não se reduzem aos de ordem neurofisiológica, pois possuem diretrizes próprias em seu dinamismo." (p.45).

Silveira (apud Coelho, 1980) define a estrutura da personalidade como:

"o conjunto de forças subjetivas
hierarquicamente organizadas, inatas e
coexistentes, ligada ao funcionamento cerebral
$o$ que resulta da comunicação com o meio
externo e interno. Estas funções regem
continuamente e de modo harmônico as
disposições genéticas do indivíduo e as suas
inter-relações com o ambiente físico e social' (
p.49)

Destacamos o uso do Método em nosso estudo sempre na referência ao grupo em suas relações com seus pacientes com ELA, onde o enfoque a essas estruturas visou sempre essas relações no trabalho.

Coelho (1980) propõe definições das estruturas intelectual, conativa e afetiva avaliadas segundo essa forma de análise proposta por Silveira. E para uma melhor compreensão dessa linha teórica inserimos em anexo as definições propostas (Anexo 4) 
Coelho (idem) situa os sentimentos com as funções de sociabilidade que se refletem nas relações interpessoais. O indivíduo sente e compreende o ambiente e assim se define como ser social.

Segue um quadro ilustrativo, compondo os setores da personalidade e os níveis determinantes em cada escala. ( Pelline,2000).

\begin{tabular}{|c|c|c|c|cc|}
\hline & \multicolumn{2}{|c|}{ Inteligência } & Conação & \multicolumn{2}{c|}{ Afetividade } \\
\hline Setores & $\begin{array}{c}\text { Contato com a } \\
\text { realidade }\end{array}$ & $\begin{array}{c}\text { Capacidade } \\
\text { Intrínseca }\end{array}$ & $\begin{array}{c}\text { Atividade no } \\
\text { meio externo }\end{array}$ & $\begin{array}{c}\text { Nível } \\
\text { Intrínseco } \\
\text { emocional }\end{array}$ \\
\hline $\begin{array}{c}\text { Categorias } \\
\text { níveis }\end{array}$ & Perpectiva & Movimento & Forma & Cor & Luminosidade \\
\hline 1 & Os & $\mathrm{M}$ & $\mathrm{F}+$ & $\mathrm{FC}$ & $\mathrm{I}$ \\
\hline 2 & Os & $\mathrm{M}$ & $\mathrm{F}-$ & $\mathrm{CF}$ & $\mathrm{I}^{\prime}$ \\
\hline 3 & $\mathrm{ps}$ & $\mathrm{M}$ & $\mathrm{F}^{0}$ & $\mathrm{C}$ & \\
\hline
\end{tabular}

1. Pleno contato com a realidade objetiva: modo estatisticamente mais freqüente na população média

2 Menor subordinação ao ambiente: freqüência ainda aferível estatisticamente

3 Predomínio do pólo subjetivo: reação muito pessoal ao estímulo do ambiente.

\section{- CAPACIDADE ASSOCIATIVA / RELAÇÃO COLOR/MONO}

A capacidade associativa relaciona-se aos mecanismos mentais que o indivíduo faz uso para interagir com o meio, sendo que a relação color e mono vão nos mostrar de que maneira o Examinando reage frente às situações do meio. Quando as respostas das pranchas coloridas são superiores as monocromáticas, revelam que o indivíduo reage frente às situações de maior apelo afetivo. Quando as monocromáticas são superiores as coloridas, revelam que o indivíduo reage às situações do cotidiano onde a mobilização afetiva é menos intensa. 


\section{- PERC - TIPO DE PERCEPÇÃO}

O tipo de percepção está diretamente relacionado com a área de localização das respostas. (Cardoso, 2006) diz;

"As modalidades na Prova de Rorschach referem-se basicamente ao processo de definição do campo perceptual que expressa o modo particular com que o indivíduo distribui sua atenção aos estímulos ambientais. Esse processo depende então, dos mecanismos de seleção e focalização da atenção" p.41).

Portanto, na análise deste índice, vamos obter a informação de como o examinando capta as situações se há capacidade ou não de estabelecer associações, a existência ou não de observação da realidade e de que maneira ela é percebida e assimilada.

Diz Campos (2007)

"A análise dos processos mentais, associados ao modo com que o indivíduo seleciona e organiza habitualmente sua experiências, permite a distinção das modalidades em dois grupos principais: o grupo das modalidades principais e o grupo das modalidades secundárias (p.44).

As modalidades principais são as esperadas no individuo adulto, o modo pelo qual ele organiza seu campo perceptual. São os fatores: G,P e p. As modalidades secundárias traduzem os modos mais subjetivos de focalização da atenção, são elas GE e E e as respostas GP,PG,p' indica algum tipo de comprometimento na percepção da realidade. 
$\mathrm{Na}$ análise do campo perceptual poderemos analisar como o outro é percebido, e de que maneira esta percepção do outro é assimilada.

A forma como o profissional capta e percebe a realidade certamente influencia seu sentir e seu fazer no contato com o paciente com ELA, daí ter sido selecionado nessa pesquisa.

\section{- INDICES AFETIVO-EMOCIONAL}

No Rorschach, a estrutura e dinâmica da Esfera Afetiva do examinando é obtida, principalmente pelo estudo das respostas as pranchas coloridas, Respostas de Cor, que são FC, CF e C; Respostas de Movimento, M, m e m'; da análise dos índices Afetividade (Af); Impulsividade ( Imp) e o Equilíbrio das Forças Subjetivas Eq e Eq'.

Nesse estudo, importam os aspectos afetivos expressos por esses índices (descritos a seguir), num enfoque que se centraliza nas relações profissionais. Ou seja, a forma como os profissionais de saúde trabalham e atendem aos pacientes com ELA e seus familiares é muito carregada de afetos. É assim, muito importante, conhecê-los no sentido de compreender essa prática e esse fazer, de forma a, se necessário, propor programas de prevenção aos profissionais na forma de reuniões clínicas e, ou supervisões institucionais.

\section{- RESPOSTAS DE COR (RC)}

Segundo Coelho, (2007), o impacto inicial desencadeado pelo estímulo colorido é involuntário, não dependendo do controle do observador. O estudo das respostas de cor nos dá acesso à afetividade, compreendida como emoções, afetos e sentimentos.

As respostas de cor permitem medir a reação e a labilidade afetiva. São três as respostas possíveis de cor; $\mathrm{FC}, \mathrm{CF}, \mathrm{C}$.

$\mathrm{O}$ número de respostas cromáticas possibilita-nos quantificar o quanto as pessoas interessam-se pelos estímulos externos, interagem e vibram com o ambiente. 
As respostas de forma-cor (FC) têm como característica principal a integração da cor e de sua estrutura formal através das manchas, em que a cor é associada à forma. Este tipo de resposta requer sensibilidade para perceber o estimulo afetivo e associar a algum significado, além de estar relacionado à capacidade para manter a atenção sobre o estímulo e analisá-lo a partir de sua delimitação formal.. As respostas FC traduzem amadurecimento psicológico, adaptação social e estilo pessoal de pensamento. (Coelho, 2007)

Nas respostas cor-forma, o estímulo cromático prevalece sobre a forma. Segundo Coelho (2007), nestas respostas os afetos são expressos de modo intenso e espontâneo expressando uma menor subordinação ao mundo real. Refletem também reações afetivas mais egocêntricas, impulsivas e instáveis.Quando o índice é muito elevado desta respostas indicam labilidade afetiva, impulsividade e irritabilidade.

As respostas $\mathrm{C}$ são determinadas exclusivamente pela cor das manchas, não se levando em conta nenhum aspecto formal. Estas respostas refletem a liberação imediata da carga afetiva em que "... o sujeito sofre passivamente o impacto da cor, ficando sua capacidade de organização formal ativa imobilizada, fazendo sua percepção fique presa aos aspectos sensorialmente mais impressivos dos estímulos." (Coelho, 2007, p.143). Estas respostas podem indicar sérias dificuldades de autocontrole.

As respostas $\mathrm{FC}>\mathrm{CF}+\mathrm{C}$ são expressas em indivíduos adultos, maduros do ponto de vista psíquico, indicando flexibilidade nas reações afetivas assim como o modo adequado pelo quais os afetos são expressos.

Por sua vez, as respostas $\mathrm{FC}<\mathrm{CF}+\mathrm{C}$ indicam instabilidade, pouco auto controle e ocorrem em adultos imaturos psiquicamente. 


\section{- ÍNDICE DE AFETIVIDADE}

Silveira, (apud Coelho, 1980) desde 1944, incluiu no estudo da afetividade as pranchas II e III, que possuem áreas vermelhas, como estímulos coloridos, elaborando seu próprio índice como expressão de afetividade. Anteriormente, Klopfer e Beck consideravam somente as pranchas VIII, IX e X. Para o autor, quando o resultado é elevado, indica acentuada suscetibilidade aos estímulos afetivos, e quando está abaixo da média reflete repressão ou falta de sensibilidade afetiva.

O autor coloca ser imprescindível associar o índice de afetividade aos outros aspectos do protocolo, principalmente com os índices de impulsividade, Eq, Eq', as respostas de cor incluindo o choque cromático, pois só assim será possível obter os dinamismos subjetivos desencadeados pelas disposições afetivas.

$\sum$ do $\mathrm{n}^{\circ}$. de respostas das pranchas coloridas

- Índice de Afetividade $=$

$\sum$ do $\mathrm{n}^{\mathrm{o}}$. de respostas das pranchas monocromáticas 


\section{- ÍNDICE DE IMPULSIVIDADE}

Rorschach ( 1974 ) define impulsividade como sendo

“(...) descargas de afeto que se acompanham de exteriorizações motoras imediatas, estabelecendo assim uma correlação de afetividade com a motilidade.Os impulsos representariam então o mais alto grau de labilidade afetiva, que só poderia ser contido através dos dinamismos implícitos nas respostas de movimento humano ( $M$ ) e respostas de forma e cor ( $F C$ ).( p.105).

Coelho (2007) assinala as diferenças entre as pranchas II e III, como sendo aquelas que provocam reações afetivas primárias, com as pranchas VIII, IX e X responsáveis em estimular os sentimentos de ordem social. A autora enfatiza que as pranchas II e III refletem um estímulo mais de ordem do biológico do que social, entendendo o biológico como sendo os impulsos e instintos.

Klopfer (apud Coelho, 1980) descreve vários tipos de fuga ao estímulo colorido. Segundo o autor, as pranchas II e III são evitadas quando o Examinando possui limitações e dificuldades em se envolver afetivamente nas situações.

Quando o índice de impulsividade encontra-se na média, significa que as disposições afetivas do indivíduo submetem-se aos impulsos mais aceitos socialmente. Quando fora da média, outros índices deverão ser estudados para sabermos de quais recursos que o indivíduo se utiliza para lidar com sua impulsividade.

O índice de impulsividade é assim expresso;

Respostas pranchas Il +111

- Índice de Impulsividade $=$

Respostas pranchas VIII+IX $+\mathrm{X}$ 


\section{- RESPOSTAS DE MOVIMENTO (RM)}

Coelho (2007) desenvolve o conceito de Silveira em relação às respostas de movimento como sendo a capacidade intrínseca de elaboração intelectual do indivíduo, resultante da interpretação das noções estabelecidas segundo concepções ou fantasias peculiares do indivíduo, portanto mais ligadas à constituição do indivíduo a seu temperamento do que às exigências do meio, caracterizando a estrutura constitucional de personalidade do indivíduo e traduzindo características pessoais próprias do examinando.

Segundo a autora (idem), ao dar uma resposta de movimento humano, o examinando não permanece mais na condição de observador do que está vendo nas manchas das pranchas e elaborando sua resposta com a idéia que veio em sua mente, ele 'sente' o movimento no sentido de dar vida ao que esta vendo e observando. "olhando o movimento de outra pessoa experimentamos em nós mesmos a sensação cinestética que teríamos se estivéssemos realizando o movimento visto".( p.131)

Assim, voltamos nossa análise para como os profissionais de saúde são capazes de dar vida e ter empatia em sua atuação.

Dando continuidade, Coelho (2007) utiliza-se do conceito de projeção adotado por Schachtel em relação às respostas de movimento humano na tendência em automorfizar a visão de mundo, "de perceber e sentir os outros através dos próprios sentimentos e percepções" ( p.131)

Nesta perspectiva, as respostas de movimento humano (M) indicam basicamente autonomia, empatia, auto controle, auto aceitação, inteligência e imaginação. As respostas de movimento animal $(\mathrm{m})$ indicam tendência à ação ou fantasias menos integradas à realidade objetiva, atitudes primárias. Por fim, m’ refere ao emprego subjetivo do movimento refletindo sentimentos de impotência, insegurança, potência frente à realidade externa. $\mathrm{O}$ esperado em adultos é $\mathrm{M}>\mathrm{m}+\mathrm{m}$. Indica riqueza de vida interior, fantasias frente à vida, que mobilizam o indivíduo a concretizá-las desde que tenha recursos para isso, indicando auto controle e autonomia. Quando $\mathrm{M}<\mathrm{m}+\mathrm{m}$ ', isso indica imaturidade psicológica, dificultando os relacionamentos interpessoais e dificuldades nas questões relacionadas ao auto controle. (Coelho, 2007). 
Acrescentamos que tais aspectos foram analisados considerando o grupo como um todo, e não os casos individuais.

\section{- EQUILÍBRIO DAS FORÇAS SUBJETIVAS (EQ E EQ')}

Ao estudar os significados das escalas cromáticas e das escalas cinésticas como referenciais essenciais das dinâmicas psíquicas, relacionadas às esferas afetivas e intelectuais da personalidade, H. Rorschach estabeleceu o que chamou de confronto entre as respostas de movimento humano com as respostas cromáticas, estabelecendo tipos diferentes de contato afetivo com o ambiente. $\mathrm{O}$ autor observa que os tipos representam dinamismos diversos, os quais podem compor-se de diversos modos, em indivíduos diferentes, assim como num mesmo indivíduo em diferentes épocas da vida. Designou este índice como Equilíbrio das Forças Subjetivas ou Eq, que Silveira traduz a própria experiência, ou seja,

“Em português experiência descreve exatamente o sentido de Erlebnis;carga subjetiva em função da qual o indivíduo experimenta as diferentes situações de vida e que assim se lhe incorporam ao modo de reagir"( Coelho, 1980,p.157).

O termo tendência, utilizado por Rorschach, embora seja termo também utilizado por Jung, tem sua interpretação bem diversa. Na concepção de $\mathrm{H}$. Rorschach, diz Coelho (1980).

Os índices Eq e Eq' revelam-nos o tipo de vivência que o indivíduo estabelece com a realidade, indicando qual dinamismo é preponderante no protocolo que estiver sendo usado. Para tanto, utiliza-se, na formulação dos índices, as RM (respostas de movimento) e as RC (Respostas de Cor) que traduzem os tipos de capacidade de contato afetivo que o indivíduo pode estabelecer com o ambiente. (Coelho, 2007). 
Para Silveira (Coelho, 2007), os índices não traduzem equilíbrio da experiência, mas o modo pelo qual o indivíduo constrói a sua experiência de vida, o seu processo, suas vivências. Esta construção, para o autor, é uma combinação específica das funções afetivas, conativas e cognitivas.

Nosso enfoque abrange todo o grupo e como o mesmo equaciona essa integração, que parece ser indispensável no tipo de trabalho por ele escolhido.

Casado (2000) analisa o índice Eq e o traduz como sendo o índice que traduz o tipo de vivência estabelecido com a realidade, o modo como o indivíduo tende a viver e reagir às diferentes situações, principalmente nos relacionamentos interpessoais. Este índice expressa as características que preponderam no comportamento manifesto, atual e consciente. (p.103)

Eq é composto pela comparação entre as Respostas de Movimento e a somatória ponderada das Respostas de Cor, e vão nos dar os Tipos Vivenciais.

Quando $\mathrm{RM}>\sum \mathrm{RC}$ traduz o tipo introversivo, ou seja, indivíduos que tendem a estabelecer relações profundas e significativas, selecionando suas relações interpessoais, estas são pouco extensas, tendo dificuldades em relacionar-se de forma mais ampla. Possui inteligência criadora e original, sendo que seus interesses estão mais voltados à vida intrapsíquica do que em direção às solicitações do meio.

Quando $\mathrm{RM}<\sum \mathrm{RC}$ traduz o tipo extratensivo: o predomínio dos elementos cromáticos em sua fórmula vivencial implica em uma relação afetiva mais fácil e expansiva do que no introversivo; é influenciável pelo ambiente, porém menos estável que o introversivo e mais lábil que o introversivo. As relações estabelecidas têm como características básicas a instabilidade e de serem pouco profundas.

Por sua vez, quando $\mathrm{RM}=\sum \mathrm{RC}$, trata-se do tipo ambigual. Os ambiguais, quando em equilíbrio com os outros aspectos do protocolo, possuem capacidade criadora, estabilidade e demais características dos introversivos, acrescidos das características dos extratensivo; ou seja, têm recursos práticos e adaptativos. No ambigual normal, os recursos introversivos e extratensivos atingem um grau de equilíbrio e de unidade. Revela capacidade tanto de estabelecer relações profundas e significativas, como de relacionar-se fácil e expansivamente com os demais. Adaptase às situações podendo interessar-se por inter-relacionamentos mais amplos e sociais, mas, quando necessário, detêm-se em aspectos mais profundos e detalhados. 
$\mathrm{O}$ ambigual dilatado ocorre quando $\mathrm{RM}=\mathrm{RC}$, apresentando ambos os índices $>2$, o que sugere predisposição para expressar seus afetos nas relações interpessoais sendo que nestes contatos intervêm as concepções pessoais e afirmativas.

Quando RM e RC = 0 ou 1,0 - tipo coartado, aparece em indivíduos cujo contato afetivo com o ambiente é superficial restrito e pobre. Revelam desinteresse em estabelecer vínculos afetivos. Geralmente são indivíduos bastante formais. (Coelho, 2007, p.251).

O índice Eq', segundo Silveira, dá acesso às fantasias infantis e às tendências mais profundas. Seguindo o enfoque de Silveira para os diferentes tipos de expressão da afetividade, o autor utiliza os mesmos valores ponderais atribuídos às respostas cromáticas de Eq para as respostas de movimento. Assim, o índice Eq' é obtido pela comparação entre a soma ponderal das respostas de movimento (M, m, m') e a soma ponderal das respostas cromáticas $(\mathrm{FC}, \mathrm{CF}, \mathrm{C})$ :

$$
\mathrm{Eq}^{\prime}=\sum \mathrm{RM}: \sum \mathrm{RC}
$$

A comparação entre os índices Eq e Eq' revelará se existe harmonia ou não entre o modo do indivíduo se relacionar em nível manifesto ( Eq ) e suas tendências internas mais profundas ( Eq' ), ou seja, observamos se há harmonia entre o que o indivíduo exprime e o que lhe é latente. A falta de harmonia poderá indicar conflitos subjetivos significativos que ocorrem, ou poderão ocorrer, pela presença de fantasias infantis ou pela presença de sentimentos de impotência e insegurança ou, ainda, presença de ambos. (Coelho, 2007).

Em nosso estudo, o conhecimento dos índices $\mathrm{Eq}$ e $\mathrm{Eq}^{\prime}$ também contribui para a compreensão de como vivências desses tipos, do grupo de profissionais, estão presentes em seu trabalho e nas relações que desenvolvem no mesmo. 


\section{- LIGAÇÃO EMOCIONAL AO AMBIENTE: A\%}

No Rorschach, as respostas de conteúdo animal refletem a ligação afetiva do Examinando com o meio, revelando o quanto ele se envolve emocionalmente com as situações. As respostas de conteúdo animal são esperadas nos protocolos de crianças, refletindo suas primeiras identificações, as quais contêm o aspecto emocional relacionado às suas primeiras experiências. No Examinando adulto, as respostas de conteúdo animal indicam o envolvimento emocional com o meio, e a média esperada destas respostas estão entre 33 a $42 \%$ do total das respostas dadas no protocolo total. Quando este índice está na média, tem como significado que, o envolvimento emocional com o meio é estável. Quando elevado, pode significar tensão emocional na ligação com o meio, em que medida envolve-se intensamente e de modo afetivo com as situações. Quando muito elevado, reflete imaturidade. Quando rebaixado reflete escassa ligação com o meio, sugerindo instabilidade. Caso seja muito rebaixado pode estar indicando apatia ou embotamento afetivo. $\mathrm{O}$ indivíduo nestes casos mostra desinteresse pelos relacionamentos inter - pessoais. e pelas situações do meio ambiente.

Destacamos a importância de saber como esse grupo liga-se afetivamente ao meio, de forma a compreender esses aspectos em sua atuação profissional.

\subsubsection{QUESTIONÁRIO DE QUALIDADE DE VIDA MCGILL}

No sentido de compreender melhor como é esse grupo de profissionais, em sua atuação profissional, em sua prática e as relações em sua vida, consideramos relevante conhecer a qualidade de vida dos mesmos, tal como definida no capítulo da Introdução.

Nesse caso, sabemos que muitos aspectos da vida das pessoas interferem em sua qualidade de vida. Dessa forma, a inclusão desse instrumento reside em nosso objetivo de conhecer as possíveis relações desses aspectos com a atuação profissional desse grupo.

Destacamos, ainda, a falta de estudos dessa natureza com profissionais, estando aí também uma contribuição do estudo na área. 
O Questionário de Qualidade de Vida escolhido foi o McGill por ser considerado mais abrangente frente aos propósitos do presente trabalho, além de o mesmo estar em processo de validação em nosso país. O questionário está inserido na íntegra em anexo ( ANEXO 5)

O Questionário de McGill é composto de quatro partes. As partes A, B e C são constituídas de 16 questões, e a parte D é uma questão aberta para listar ou descrever "as coisas que tiveram o maior efeito na sua qualidade de vida nos últimos dois dias".

A parte A não entra na contagem dos pontos. Serve de exemplo para o examinando e, ao mesmo tempo situa-nos em termos gerais saber como ele esta se sentindo em todos os aspectos de sua vida.

A parte $\mathrm{B}$ refere-se à presença de Sintomas Físicos ou Problemas Físicos e a parte $\mathrm{C}$ contem questões referentes a Sentimentos e Pensamentos. Para cada uma das partes foram elaboradas questões que se referem a aspectos manifestos, ou seja, conscientes e conhecidos pelos sujeitos.

O próprio participante respondeu ao questionário na presença da autora do trabalho, devendo sempre responder numa escala de 0 a 10 , de menor à maior intensidade no quesito avaliado na referida questão.

Como nos demais instrumentos, optamos por fazer uma análise do grupo como um todo apresentando de forma numérica (em porcentagem) os resultados obtidos em cada uma das 16 questões que compõem o questionário, para facilitar a compreensão do leitor. 


\section{CAPÍTULO IV- APRESENTAÇÃO E DISCUSSÃO DOS RESULTADOS}

Nesse capítulo serão apresentados os resultados obtidos em cada instrumento empregado na presente pesquisa.

Inicialmente apresentamos os resultados, em porcentagem, sempre considerando o grupo, e, na medida do possível, fazemos nossas observações e reflexões à luz dos dados obtidos e de colocações citadas na Introdução do trabalho, já se configurando nossa Discussão dos resultados.

Optamos por deixar a síntese dos dados que nos pareceram mais relevantes com a referida discussão para o próximo capitulo (Capitulo V), onde será possível tecer as considerações finais desse trabalho.

\subsection{ENTREVISTAS}

As 25 perguntas do roteiro (Anexo 3) respondidas pelos participantes foram tabuladas e os dados apresentados a seguir, buscando encontrar as unidades de sentido que cada pergunta buscou investigar.

Assim, no que diz respeito à identificação pessoal obtivemos o que se segue:

- em relação à nacionalidade e procedência verificamos que,

$100 \%$ brasileiros

81,82\% do estado de São Paulo

$18,18 \%$ de estados do Nordeste 
- quanto ao sexo,

\section{$81,82 \%$ do sexo feminino \\ 18,18 do sexo masculino}

- em relação à faixa etária;

$18,18 \%$ na faixa de $20 \dashv 29$

$45,46 \%$ encontram-se na faixa etária de $30-39$

$36,36 \%$ na faixa de $40 \dashv 49$

- em relação ao estado civil;

$\mathbf{4 5 , 4 5 \%}$ solteiros

$18,18 \%$ são separados ou divorciados.

$36,37 \%$ casados

- quanto ao número de filhos,

$45,46 \%$ não têm filhos

36,36 têm 01 filho

9,09\% têm 02 filhos

9,09\% têm 04 filhos

Podemos sintetizar os dados referentes à identificação através do quadro abaixo, 


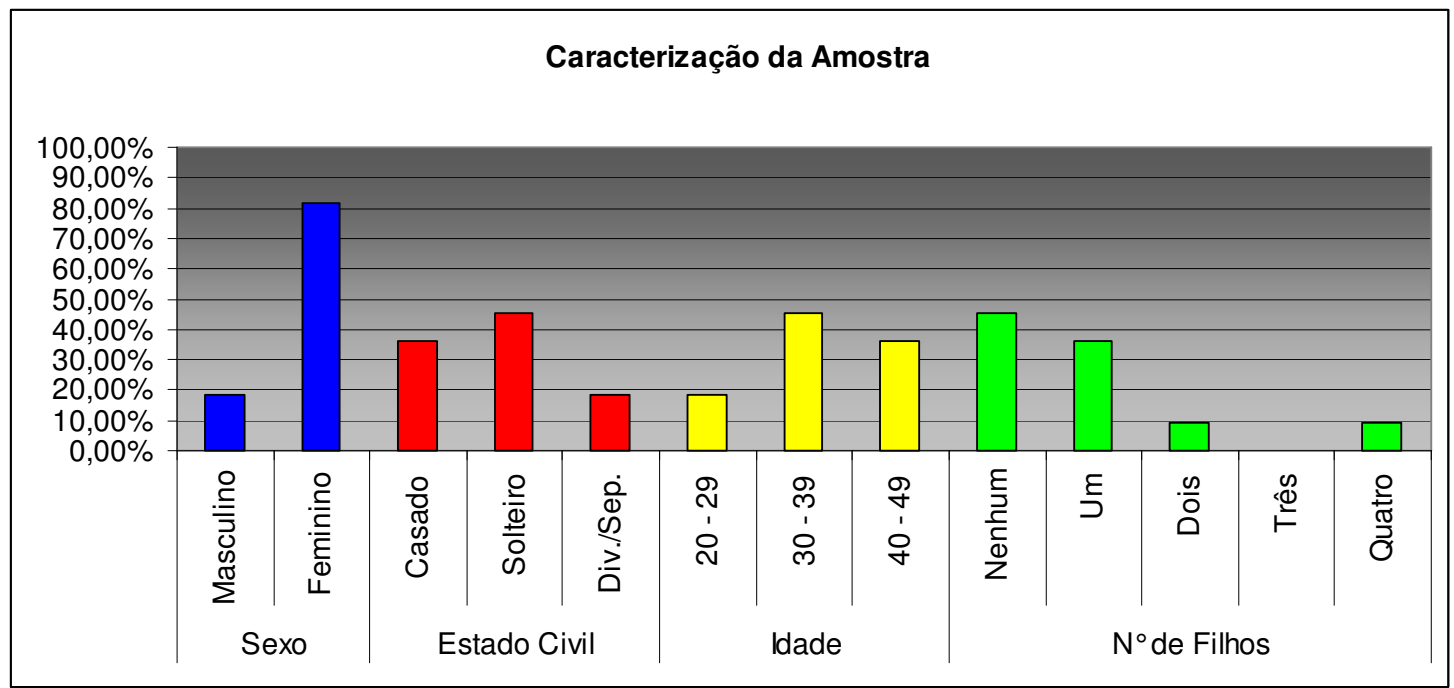

Observamos pelo gráfico que a predominância dos sujeitos é do sexo feminino, sendo que a maioria encontra-se na faixa etária de 30 - 39 anos, seguido do grupo que está entre 40 - 49 anos e o grupo menor que está entre 20 - 29 . Somando os solteiros com os separados e divorciados teremos 63,63\% em detrimento dos profissionais casados que representam 36,37 da amostra. 54,54\% possuem filhos sendo que 45,46\% não têm filhos.

Em relação aos dados referentes à identificação profissional, temos;

- Quantos anos de formação no curso de graduação;

$45,45 \%$ estão formados no intervalo de 1 a 9 anos;

$45,45 \%$ de 10 a 19 anos;

$9,09 \%$ de 20 a 29 anos;

Somando os grupos que possuem de 10 a 19 anos e 20 a 29 anos, o tempo de formação representa 54,45\% em relação à amostra. 
Estes dados levam-nos a perceber que se trata de um grupo de profissionais na sua maioria na fase adulta e com período longo de formação, o que nos faz supor que se trata de um grupo mais amadurecido no âmbito profissional

Para a elaboração do quadro 1 foram transcritas as respostas dos profissionais, com algumas alterações, sem comprometer o conteúdo, preservando o anonimato dos mesmos.

\section{QUADRO 1. Fatores contribuíram para a escolha da profissão e} expectativas.

\begin{tabular}{|c|c|c|}
\hline & Fatores para a escolha da profissão & $\begin{array}{c}\text { Atendeu } \\
\text { expectativas }\end{array}$ \\
\hline 01 & Identificação, busca de contato com as pessoas. & mais ou menos. \\
\hline 02 & Unir minhas habilidades com as exigências da profissão & Sim. Muito \\
\hline 03 & Atender indivíduos com doenças graves & Sim \\
\hline 04 & Frustração na minha profissão anterior & Sim \\
\hline 05 & O vestibular. não entrei.tentei outro curso. & Sim \\
\hline 06 & Satisfação pessoal, desafio, ganhar bem. & Sim \\
\hline 07 & Empatia & Sim \\
\hline 08 & Poder minorar o sofrimento do outro. Levei uma queda & Ainda não \\
\hline 09 & séria que foi decisiva na minha escolha de profissão & Sim \\
\hline 10 & Possibilidade de intervir & Sim \\
\hline 11 & Poder ajudar o próximo & \\
\hline
\end{tabular}

Em relação ao QUADRO 1 observamos que 81,82\% estão satisfeitos com a profissão escolhida à medida que as expectativas dos mesmos foram atendidas. Somente $9,09 \%$ sentem que suas expectativas não foram atendidas e 9,09\% colocaram mais ou menos.

A equipe, como um todo, escolheu a profissão pela empatia com o outro, poder ajudar, atender pessoas em estado de sofrimento com doenças graves, intervir, 
criar, buscar algo melhor para si. Somente 9,09\% não conseguiram situar-se dentro da escolha feita na profissão. A questão do sofrimento e da empatia pelo outro se faz presente na maior parte das respostas. Este dado é reforçado pelas respostas sobre a escolha das profissões.

Pode-se pensar num grupo maduro e que escolheu a profissão que mais o atende, seus desejos ou expectativas.

Para elaborar o quadro 2 levamos em conta as respostas dadas com respeito ao número de horas trabalhadas na ABRELA e fora; além do tempo na associação.

QUADRO 2. Tempo de permanência e carga horária semanal na ABRELA, na ABRELA, outros empregos, quantos, número de horas trabalhadas por semana no geral.

\begin{tabular}{|c|c|c|c|c|}
\hline & $\begin{array}{c}\text { Tempo } \\
\mathrm{Na} \\
\text { ABRELA }\end{array}$ & $\begin{array}{c}\text { Carga horária de } \\
\text { atendimento por } \\
\text { semana na ABRELA }\end{array}$ & $\begin{array}{c}\text { Outros } \\
\text { empregos,atividades, } \\
\text { quantos }\end{array}$ & $\begin{array}{l}\text { Número de } \\
\text { horas } \\
\text { trabalhadas } \\
\text { por semana }\end{array}$ \\
\hline 1 & 2 anos & 30 horas & 01 & 34 \\
\hline 2 & 3 anos & 05 horas & 02 & 60 \\
\hline 3 & 9 anos & 25 horas & 02 & 70 \\
\hline 4 & 6 anos & 06 horas & 02 & 60 \\
\hline 5 & 9 anos & 05 horas & 02 & 60 \\
\hline 6 & 6 anos & 40 horas & - & 40 \\
\hline 7 & 9 anos & 05 horas & 02 & 50 \\
\hline 8 & 4 anos & 30 horas & 01 & 50 \\
\hline 9 & 4 anos & 05 horas & 02 & 75 \\
\hline 10 & 5 anos & 05 horas & 03 & 60 \\
\hline 11 & 4 anos & 08 horas & 01 & 70 \\
\hline
\end{tabular}


Pelos resultados apresentados no quadro 2, observamos que $81,81 \%$ dos profissionais possuem mais de um emprego, trabalhando em média 57 horas por semana e, levando-se em conta 05 dias úteis da semana, os profissionais trabalham em média 11 horas por dia. Destas 57 horas em média por semana, $26 \%$ do tempo dos profissionais é dedicado ao atendimento dos pacientes portadores de Esclerose Lateral Amiotrófica. Os profissionais que participaram deste estudo estão na ABRELA, em média, há 6 anos.

A maioria destes profissionais é composta de voluntários, alunos de cursos de especialização, mestrado, doutorado e permanecem no Ambulatório mesmo quando seus respectivos cursos acabam. 90,90\% possuem mais de 01 emprego o que nos leva a supor uma sobrecarga de trabalho que pode levar a uma situação de estresse.

O fato de, a maioria do grupo ser do sexo feminino e ter filhos, pode reforçar esta possibilidade de sobrecarga de trabalho, preocupações e outras questões.

Severo (1993), confirma estas colocações ao mencionar as dificuldades de atuação do profissional de saúde no que se refere à longa jornada de trabalho e à pobre remuneração.

Por outro lado, nesse grupo em particular, observamos que esses profissionais ligados aos pacientes com Esclerose Lateral Amiotrófica, respectivos cuidadores e familiares são dedicados, estabelecendo vínculos com o Ambulatório que vão além de suas obrigações acadêmicas. Uma parte significante do tempo destes profissionais é dedicado ao atendimento destes pacientes. É importante ressaltar que a maioria não tem remuneração, alguns possuem bolsas de estudo e poucos são vinculados a UNIFESP/EPM.

Os quadros seguintes referem-se a situações de atendimentos que desencadearam sentimentos de frustração, ansiedade, raiva, de terem se sentido felizes, amparados, recompensados, ameaçados, cobrados e sentimentos de tristeza. A síntese dos resultados foi feita baseando-se nas respostas de mesmo significado, sentido e intenção. 
QUADRO 3 - Respostas dos profissionais em relação ã situações de atendimento que se sentiram frustrados

-falta de material para ajudar os pacientes em determinado momento.

- o que frustra é quando não tem material necessário para o paciente e não dá para suprir o necessário. Eles esperam tanto e quando não têm eles (os pacientes) acabam incomodando.

- não me lembro

- quando avisei minha família que ia mudar de área

- comunicação do paciente se queixando. ' me' trouxe sentimento ruim de perceber que embora a gente se esforça não é o ideal para as pessoas

- como as coisas têm andando na neuro.... as relações interpessoais

- o mais marcante foi quando veio uma paciente com a família, fora de dia. Ele quis passar na frente dos agendados e ainda escreveu uma carta reclamando da espera.

- impossibilidade em atender as necessidades dos pacientes amplamente

- nunca me senti frustrado. as dificuldades mobilizam para as situações melhorarem

- não me lembro

- não ser reconhecido

As respostas do quadro 3 podem ser sintetizadas da seguinte maneira;

\begin{tabular}{|l|c|}
\hline \multicolumn{1}{|c|}{ Falta de material } & $18,18 \%$ \\
\hline Não se lembra & $27,28 \%$ \\
\hline Mudar de área & $09.09 \%$ \\
\hline Queixas do paciente & $18,18 \%$ \\
\hline Relacionamento com os colegas & $09,09 \%$ \\
\hline Não atender necessidades do paciente & $09,09 \%$ \\
\hline Não ser reconhecido & $09,09 \%$ \\
\hline
\end{tabular}

Analisando as respostas em que os profissionais sentiram-se frustrados, seguindo a definição de Lagache (1966) verificamos que todas as respostas estão voltadas para dar um bom atendimento aos pacientes; materiais, agendamentos e 
outros recursos. Quando há falha em algum item, e os pacientes reclamam, os profissionais sentem-se não reconhecidos e nem gratificados, sendo esses os obstáculos vivenciados por esse grupo.

A questão da necessidade de reconhecimento é muito forte e à medida que associam diretamente com o que consideram um bom atendimento, o nível de frustração do grupo encontra-se num nível elevado e, possivelmente esse sentimento contribui para uma situação de sobrecarga nos profissionais. Provavelmente, os pacientes sentem-se prejudicados e não atendidos em suas necessidades, projetando nos profissionais os déficits institucionais.

A relação entre paciente e profissional fica permeada de frustração, de cobrança de ambos os lados: o profissional que espera um reconhecimento e o paciente que espera ser atendido em suas necessidades. Ambos vivenciam um baixo limiar ao sentimento de frustração e de não reconhecimento.

Os profissionais mostram-se dessa forma, sensíveis à projeção dos pacientes, como diz Jeammet (1982), podemos aí remeter-nos à noção de transferência, uma vez que os pacientes transferem para o profissional sentimentos afetuosos, hostis e outros

Os profissionais que responderam "não me lembro" são profissionais que provavelmente estão usando mecanismos de negação e/ou racionalização como forma de equacionar situações difíceis de serem lidadas, não conseguindo ter registro consciente das mesmas.

Kubler - Ross (1987), assim como Bellodi (2001), discutem o mecanismo de defesa de negação um importante recurso para o paciente como forma de lidar com sua angústia e medo frente à doença. Podemos também considerar que esse mecanismo pode ser empregado pelo profissional.

Consideramos relevante as colocações de Bleger(1984) de que o contato com a doença e com a morte faz do trabalho da equipe de saúde uma tarefa altamente ansiogênica, a qual pode levar a mecanismos de defesa. 
O quadro 4 refere-se às situações de ansiedade vividas pelo grupo

\section{QUADRO 4 - Respostas dos profissionais em relação às situações de atendimento que se sentiram ansiosos}

- me senti mal. Paciente em coma, precisando fazer exame e o marido não tinha dinheiro. Fizemos coleta, mas não fechou a ferida na alma dele, de não ter dinheiro para um exame que a mulher precisava fazer.

- um paciente sem atenção do seu cuidador

- me deixa nervosa os primeiros atendimentos. Quando chegam para receber o diagnóstico de ELA. Nem sempre temos respostas para oferecer.

- estava em casa, tocou o bip e o recado foi que o paciente estava com perigo de vida....

- falar com o paciente da doença

-não conseguir resolver algo que representa a vida do paciente por falta de material

- quando falta material

- atendi um paciente que estava chorando e quase tentando suicídio. Tentei agendar tudo ao mesmo tempo. O médico mandou comprar um jazigo.

- ansiosa para resolver problema com estagiário

- quando tem eventos e não depende só da gente

- fatos relevantes da vida pessoal e realização da gastro 
Em relação ao QUADRO 4 podemos sintetizar os resultados em que os profissionais sentiram-se ansiosos ;

\begin{tabular}{|c|c|c|}
\hline Respostas & $\mathrm{n}^{\text {o de } \mathrm{R}}$ & $\%$ \\
\hline Descuido do cuidador & 01 & $9,09 \%$ \\
\hline Falar sobre a doença & 02 & $18,19 \%$ \\
\hline Falta de material & 02 & $18,19 \%$ \\
\hline Problemas com a equipe & 02 & $18,19 \%$ \\
\hline Paciente em estado de risco de vida & 01 & $9,09 \%$ \\
\hline Fatos relevantes da vida pessoal/ & 01 & $9,09 \%$ \\
\hline realização da gastro & & $9,09 \%$ \\
\hline Realização de eventos & 01 & $9,09 \%$ \\
\hline Paciente sem recursos financeiros & 01 & \\
\hline
\end{tabular}

Analisando o quadro 4 , podemos inferir que as situações apontadas pelos profissionais se devam ao fato destes, não terem as respostas que gostariam de dar para os pacientes, ficando frente ao desconhecimento e impotência diante do saber. Dessa forma, a maioria traz ansiedades de natureza depressiva, se considerarmos o referencial de Tardivo (1997) que se apoia nas concepções de M. Klein (1982). Assim, observamos que as ansiedades aqui são decorrentes do interesse e da preocupação com o paciente, numa situação relacionada à posição depressiva. E, ao mesmo tempo, não identificamos nesse grupo respostas que pudessem denotar quaisquer respostas ligadas a Transtornos de Ansiedade.

Todas as respostas dadas pelos profissionais relacionam-se direta ou indiretamente a não poderem amenizar o sofrimento dos pacientes, seja por falta de materiais necessários a um melhor atendimento ou de momentos difíceis, como o de dar o diagnóstico de ELA, falar sobre a doença.

Uma resposta destacou-se: a de um profissional que responde em primeiro lugar que a uma situação muito particular em sua vida que lhe trouxe ansiedade e logo após fala da realização da gastro nos pacientes. A realização deste procedimento acontece quando os pacientes já se encontram num considerável grau de debilitação, 
representando uma nova fase da doença, em que o paciente tem que se readaptar à novas situações A situação a que o profissional se refere e o processo do adoecer da ELA remetem a situações desconhecidas, novas, em que há naturalmente uma ruptura da estabilidade psíquica instalando-se sentimentos de medo, insegurança e de ansiedade; vida e processo de morrer apresentando-se concomitantemente.

A resposta do profissional para que outro profissional mandasse o paciente procurar um jazigo, mostra-nos a medida da ansiedade e sofrimento que estes profissionais vivem no atendimento a estes pacientes. Na relação, os profissionais colocam-se como aqueles capazes "dar conta" do paciente e este coloca o profissional como sendo alguém capaz de restituir-lhe a saúde, a vida. Quando o princípio da realidade se impõe, presentificam-se sentimentos de ansiedade e impotência de ambos os lados, os quais acabam sendo canalizados e simbolizados para falta de material, incompreensão dos colegas e outras questões. Estas questões são importantes, mas são fatores desencadeantes da ansiedade dos profissionais. $\mathrm{Na}$ verdade, na relação com o paciente, a todo o momento permeia a doença, o vivenciar de todas as etapas, tão conhecidas para estes profissionais e o desenlace inevitável, que é a morte.

Como vimos, Barus - Michel (2001) compreende a doença como sendo uma ruptura da estabilidade psíquica, e dessa forma, o profissional também sente a necessidade de defender-se., em função de seu próprio sofrimento.

$\mathrm{O}$ quadro 5 contem as respostas nas quais os profissionais sentiram raiva nos atendimentos realizados 


\section{QUADRO 5 Situações de atendimento nas quais sentiram raiva}

- paciente grave e o PS não quis internar

- quando o paciente não tem a atenção que precisa

- estar atendendo alguém e entra um profissional de sua área e começa a dar palpite

- chega medicamento ninguém me avisa. Quando não põe na geladeira. quando as pessoas não assinam.

- o paciente que atendi fora do agendamento e reclamou. Ele não parava de gritar.

- não gosto quando a pessoa distorce o que você falou.

- pessoa questiona para que a ABRELA serve se ela não tem reabilitarão.estamos tentando oferecer o que esta dentro da nossa possibilidade. Tenho consciência que merece resposta de cura quando alguém esta frente da morte. Mas na hora dá raiva.

- Quando os colegas não aceitam críticas, não aceitam estruturar melhor o serviço

- fui visitar um paciente e ele estava amarrado na cama.poucas coisas que podiam ser feitas para ele sair deste desconforto. Sensação que tive de justiceiro.... Achei que foi maldade.....

-da desorganização no atendimento, da dinâmica do funcionamento

- negligência do cuidado por parte do paciente. No atendimento com a superficialidade dos outros profissionais.

Quanto às respostas relacionadas ao quadro 5 sobre as situações de atendimento em que os profissionais vivenciaram sentimentos de raiva podemos verificar que; 


\begin{tabular}{|c|c|c|}
\hline Respostas & $\mathrm{n}^{\mathbf{o}}$ de $\mathrm{R}$ & $\%$ \\
\hline Falta de recursos para atender as necessidades \\
do paciente & $27,26 \%$ & 03 \\
\hline Questões relacionadas com os colegas & $36,36 \%$ & 04 \\
\hline Reações por parte dos pacientes & $18,19 \%$ & 02 \\
\hline $\begin{array}{c}\text { Questões relacionadas ao atendimento no } \\
\text { ambulatório }\end{array}$ & $18,19 \%$ & 02 \\
\hline
\end{tabular}

05 respostas ( 45,46\%) , quando ele não está sendo atendido em suas necessidades: a falta de cuidados, negligência, falta de atenção e de falhas na instituição, como faltas de vagas, materiais e outros. 02 respostas $(18,18 \%)$ relacionadas a questões de organização, o que acaba prejudicando o atendimento ao paciente. 02 respostas $(18,18 \%)$ de situações em que o paciente mobilizou sentimentos de raiva e 02 respostas $(18,18 \%)$ referindo-se ao interrelaciomento com os colegas. Aqui notamos a presença de sentimentos derivados do instinto de morte, seguindo referencial de Tardivo (1997), mas que também podemos compreender como uma reação à impossibilidades de resolver o que não podem.

Nas respostas, de modo geral, os pacientes continuam mobilizando e projetando sentimentos de impotência nos profissionais. As possíveis falhas institucionais são, na sua maioria, levadas ao âmbito pessoal, refletindo provavelmente na relação com os pacientes. Quando os pacientes se posicionam de alguma maneira, podem potencializar e projetar nos profissionais, sentimentos de impotência, os quais, muitas vezes revertem-se em sentimentos de raiva como forma de lidar não só com a doença, mas também das falhas da instituição traduzida pela falta de materiais, medicamentos etc.; os profissionais ficam como representantes e responsáveis por todas as frustrações vividas pelos pacientes, bem como os profissionais também acabam projetando suas limitações e frustração nos pacientes, havendo uma mútua situação de projeção, tentando evitar-se um confronto com as angústias e impotência diante das situações que se presentificam - os profissionais querem curar e os pacientes, serem curados. 
Assim, observamos o que Bellodi (2001) apontou acerca dos conceitos de transferência e contra transferência quando afirmou que o paciente repete com o médico, no presente, atitudes, fantasias e desejos. E o médico, por sua vez, alvo desse movimento, reage ao ser deslocado nesse outro lugar pelo paciente; assim o profissional reage às expectativas dos pacientes terem resolvidas situações que, na maior parte das vezes, escapa ao poder real do profissional

O quadro 6 diz respeito às respostas dos profissionais em relação às situações de atendimento que se sentiram felizes, amparados, recompensados

\section{QUADRO 6 - Respostas dos profissionais: sentimentos de felicidade, amparo.}

- atender o pai (cita o nome de uma paciente). Ele é um exemplo de vida.

- quando vê o paciente grave e conseguir tirar ele da crise.

- quando o paciente consegue o que precisa

- são muitas, quando um paciente se recupera.

- quando tudo vai bem

- quando percebo que o trabalho tem resultados positivos para o paciente. Quando atinjo meus objetivos.

- paciente já tinha falecido. A família vem e devolve os materiais emprestados e vem agradecendo. Isso dá a sensação de missão cumprida. Mesmo quando a gente acha que fez pouco e a família acha que fez muito. É gratificante.

- geralmente pacientes que atendo há muito tempo e quando reencontro tem uma relação de amizade.

- paciente veio aqui só para agradecer

- quando conseguem fazer os exercícios

- quando consegue a adesão ao tratamento com bons resultados

Agrupando as respostas do quadro 6 obtivemos as seguintes respostas;

\begin{tabular}{|c|c|c|}
\hline Respostas & $\mathrm{n}^{\text {o. de } \mathrm{R}}$ & $\%$ \\
\hline Quando a família demonstra gratidão para com a equipe & 02 & $18,18 \%$ \\
\hline Quando o profissional consegue tirar o paciente da crise & 02 & $18,18 \%$ \\
\hline Quando o paciente está indo bem no tratamento & 03 & $27,27 \%$ \\
\hline Reconhecimento do trabalho da equipe por parte do paciente & 03 & $27.27 \%$ \\
\hline Há recursos para atender o paciente no Ambulatório & 01 & $9,09 \%$ \\
\hline
\end{tabular}


Analisando as respostas de situações em que o profissional se sentiu feliz, amparado, recompensado, entendendo sentimentos de felicidade, amparo e recompensa relacionados ao prazer e à estabilidade psíquica, encontramos $100 \%$ das respostas relacionadas à recuperação, bem estar, gratidão da família, atendimentos bem realizados, pacientes saírem da crise etc. sendo que as respostas com maior freqüência referem-se quando o paciente está indo bem no tratamento e reconhecimento do trabalho da equipe por parte do paciente representando $54,54 \%$ do conjunto das respostas.

Este resultado é extremamente importante ao relacionarmos com os objetivos propostos pelo presente trabalho, que é o de analisar os aspectos afetivos e emocionais encontrados na relação dos profissionais de saúde e seus pacientes com ELA. É interessante observar que, embora os profissionais tenham incorporado em sua praticas profissionais o lidar com uma doença degenerativa, sem prognóstico de cura, os sentimentos de felicidade, amparo e reconhecimento estão relacionados às “melhoras" do paciente e reconhecimento das famílias.

Aqui reconhecemos a prevalência de sentimentos derivados do Instinto de Vida, segundo o referencial de Tardivo (1997); referem-se a aspectos de evolução e saudáveis, considerando ainda a teoria de M Klein (1982).

Percebemos nitidamente a ambivalência nos profissionais (uma vez que denotaram frustração, tristeza e mesmo raiva ao lado desse sentimento de felicidade e recompensa). A ambivalência pode ser encarada como forma de lidar com uma carga grande de frustração, ansiedade e impotência. Mediante o reconhecimento por parte dos pacientes, cuidadores e familiares, o profissional sente -se gratificado e esse sentimento é de suma importância para que possa continuar tendo esperança, na tentativa de melhorar a qualidade de vida de pacientes com ELA e seus familiares. 
O QUADRO 7 reúne as respostas dos profissionais em relação a situações de atendimento em que sentiram-se ameaçados

\section{QUADRO 7 - Respostas dos profissionais que se sentiram ameaçados}

- por uma profissional ( cita o nome ) que sei que não gosta de mim

- nunca me senti ameaçada

- nunca

- fiz intervenções sob pressão

- não me lembro

- não me lembro

- nunca me senti ameaçada

- uma voluntária divulgou uma informação errada contra meu trabalho e da ABRELA. Falou que não estávamos cumprindo nosso papel. Teve repercussão. Me senti muito agredida.

- ameaçada fisicamente não me lembro.emocionalmente no paciente que reclamou de mim. Me senti ameaçada, injustiçada.

- Quando o grupo coloca sua integridade em jogo. Da disputa entre colegas

- não me lembro.

Pelas respostas acima observamos em relação a sentirem-se ameaçados,

\begin{tabular}{|c|c|}
\hline Pelo próprio grupo de trabalho & $36,37 \%$ \\
\hline Nunca se sentiu ameaçado & $54,54 \%$ \\
\hline Pelos pacientes & $9,09 \%$ \\
\hline
\end{tabular}

Entendendo ameaça como sentimento que desestabiliza situações e/ou pessoas, obtivemos 06 respostas $(54,55 \%)$ de profissionais que nunca se sentiram ameaçados. Estas respostas podem estar indicando mecanismos de negação e/ ou racionalização. Em 03 respostas $(27,27 \%)$ o sentimento de ameaça está relacionado a 
questões pessoais. 01 resposta $(9,09 \%)$ diz respeito ao inter-relacionamento entre os colegas e 01 resposta ( 9,09\%) diz respeito a comportamento de paciente.

O quadro 8 relaciona-se bastante ao quadro anterior.

QUADRO 8 - Respostas dos profissionais em relação ã situações de atendimento em que se sentiram cobrados

- diariamente os pacientes cobram muito a questão da cura.célula tronco, como anda a pesquisa e por ai vai...

- não tem.

- sempre..em todas as situações

- quando o paciente não esta vendo os resultados que deseja

- cobrada de ter que estudar mais.

- o que estamos vivendo hoje, ninguém entende o que a gente faz. não dá para cumprir a lista de espera.

- nunca me senti cobrada

- acontece sempre. O paciente vem sempre na perspectiva que a gente tenha a cura da doença tem um paciente que cobra e xinga......

- cobrada de quere mais do que você pode dar. Meu trabalho é voluntário.

- no horário de almoço.

- não me sinto

A partir do quadro acima tivemos os seguintes resultados;

\begin{tabular}{|l|c|}
\hline Pelos pacientes & $27,27 \%$ \\
\hline Nunca se sentiu cobrada & $27,27 \%$ \\
\hline Em todas as situações & $9,09 \%$ \\
\hline Em estudar mais & $9,09 \%$ \\
\hline Pelas pessoas em geral & $18,18 \%$ \\
\hline Quando estou em horário de almoço & $9,09 \%$ \\
\hline
\end{tabular}


Compreendendo cobrança como sendo algo que é esperado e/ou exigido o qual não ocorre, por uma série de motivos, verificamos que 4 respostas (36,37\%) relacionam-se aos pacientes, quando estes vêm questionar as pesquisas, os resultados, a cura da doença e a fila de espera. Esta postura dos pacientes, de questionarem, e dos profissionais de sentirem-se cobrados é que, provavelmente, ativa sentimentos de impotência nos profissionais, os quais acabam racionalizando isto como sendo cobrança por parte dos pacientes . 03 respostas $(27,27 \%)$ relatam nunca se sentiram cobradas, o que chama atenção, na medida em que o trabalho em si de atendimento em pacientes com ELA e destes atendimentos estarem inseridos numa parceria da ABRELA com a Neuromuscular da UNIFESP/EPM tal cobrança é algo esperado em vários níveis: de atendimento, dos pacientes, de pesquisa etc. Não se sentir jamais cobrado, nestas circunstâncias, sugere mecanismos de negação presentes, como forma de dar conta de situações difíceis de serem vivenciadas.

Vimos, na Introdução que o mecanismo de negação é bastante usado e necessário quando se fala de pacientes, (Kubler - Ross , 1987 e Bellodi, 2001). Porém deve-se questionar o emprego desse mecanismo, em especial se for mais intenso, uma vez que é esperado que o profissional consiga dar mais conta do sofrimento

01 resposta $(9,09 \%)$ em que o profissional sente-se cobrado em todas as situações, sugere vivências de muito sofrimento e de se sentir exposto a tudo e a todos. 01 resposta $(9,09 \%)$, de estudar mais, parece condizente com o ambiente em que seu trabalho é desenvolvido, bem como de auto-exigência, 02 respostas $(18,18 \%)$ relacionam-se à questões pessoais em que permeia a questão de não poder ser cobrado na medida em que s trabalham como voluntários, revelando como defesa a negação, uma vez que, por ser um trabalho voluntário, ficaria isento de qualquer exigência. Porém, o tempo de permanência na ABRELA é longo, como vimos anteriormente, o que nos mostra os mecanismos de racionalização que se fazem presentes como forma de dar sustentação aos sentimentos relacionados a impotência e fragilidade e fadiga.

Como vimos, Severo (1993) refere-se a essas dificuldades, assim como Bleger (1984) quando se referem ao trabalho do psicólogo, e podemos estendê- las a outros profissionais no contexto institucional 


\section{QUADRO 09 - Respostas dos profissionais em relação aos atendimentos em que sentiram tristeza,}

- morreu a esposa de uma paciente

- despedida. da morte

- quando o paciente falece

- quando o paciente não volta mais andando para o atendimento.

- quando os pacientes morrem fora da hora....,,.,vão para lugares que não tem cuidados

- nunca senti

- um senhor do PS. Morte é a parte da humanização, tem que ser um momento rico, valioso. Este paciente teve parada cardíaca na rampa.

- de ver a banalização no atendimento. A visão administrativa banaliza. O egoísmo geral da humanidade.

- sempre que um paciente tem uma evolução rápida. A gente fica triste com a impossibilidade dele e com a sua. Tenta ajudar mas ninguém é capaz de impedir o prejuízo da doença. Bom seria que ninguém tivesse ELA.

- quando morre o paciente. também quando a família abandona o paciente.

- relato do paciente na reunião da ABRELA. Porque o paciente se colocou numa posição que a cura da doença é um trem que vai chegar. Outro veio cantar e trouxe uma fita cassete e fez um relato da doença.

Podemos verificar que,

\begin{tabular}{|c|c|}
\hline Morte da esposa de um paciente & $9,09 \%$ \\
\hline Morte do paciente & $36,37 \%$ \\
\hline Piora do paciente & $27,27 \%$ \\
\hline Nunca senti tristeza & $9,09 \%$ \\
\hline Banalização no atendimento & $18,18 \%$ \\
\hline
\end{tabular}


Podemos entender o sentimento de tristeza como parte do grupo dos sentimentos que provocam uma ruptura da estabilidade psíquica promovendo sofrimento psíquico. (Barus-Michel, 2001)

Tendo como referencial a questão de ser a tristeza um fator de ruptura, é interessante observar que 10 respostas $(90,91 \%)$ estão relacionadas ao agravamento do paciente, ao óbito e a um atendimento que não preenche as necessidades do paciente, mostrando um envolvimento e responsabilidade por parte do profissional, ou seja, uma identificação com a situação de dor do paciente. Em 01 resposta $(9,09 \%)$, o profissional responde que nunca sentiu tristeza. Provavelmente, este profissional está fazendo uso de mecanismos de negação e/ou racionalização, pois a resposta "nunca" nos leva a pensar que este profissional está com dificuldades e pouca disponibilidade psíquica para entrar em contato com situações normalmente desencadeadoras de tristeza. Parece-nos que a dor não está conseguindo ser vivenciada.

Podemos ainda inferir a presença desse Sentimento que é decorrente da posição depressiva (Klein, 1982), o que denota a evolução desse grupo (Tardivo, 1997).

\subsection{RESULTADOS DOS ÍNDICES DO RORSCHACH}

Vamos apresentar os resultados obtidos no Rorschach nos índices escolhidos e apresentados no capitulo III, sempre considerando o grupo os resultados apresentados em porcentagem, de forma a se visualizar melhor como se posicionam 11 protocolos dos profissionais no Método de Rorschach; 
QUADRO 10 - CAPACIDADE ASSOCIATIVA / RELAÇÃO COLOR/MONO

\begin{tabular}{|c|c|c|c|c|}
\hline & Protocolo Total & Mono & Color & Relação color/mono \\
\hline 1 & $37 \leftrightarrow$ & $12 \leftrightarrow$ & $25 \leftrightarrow$ & Color $>$ mono \\
\hline 2 & $36 \leftrightarrow$ & $15 \leftrightarrow$ & $21 \leftrightarrow$ & Color $>$ mono \\
\hline 3 & $29 \leftrightarrow$ & $13 \leftrightarrow$ & $16 \downarrow$ & Color $>$ mono \\
\hline 4 & $29 \leftrightarrow$ & $12 \leftrightarrow$ & $17 \leftrightarrow$ & Color $>$ mono \\
\hline 5 & $29 \leftrightarrow$ & $11 \downarrow$ & $18 \leftrightarrow$ & Color $>$ mono \\
\hline 6 & $30 \leftrightarrow$ & $12 \leftrightarrow$ & $18 \leftrightarrow$ & Color $>$ mono \\
\hline 7 & $24 \downarrow$ & $10 \downarrow$ & $14 \downarrow$ & Color $>$ mono \\
\hline 8 & $16 \downarrow$ & $09 \downarrow$ & $07 \downarrow$ & Color $<$ mono \\
\hline 9 & $23 \downarrow$ & $08 \downarrow$ & $15 \downarrow$ & Color $>$ mono \\
\hline 10 & $19 \downarrow$ & $06 \downarrow$ & $13 \downarrow$ & Color $>$ mono \\
\hline 11 & $29 \leftrightarrow$ & $09 \downarrow$ & $20 \leftrightarrow$ & Color $>$ mono \\
\hline
\end{tabular}

Consideramos os sinais $\leftrightarrow$ média; $\uparrow$ acima; abaixo $\downarrow$

As tabelas com os valores esperados encontram-se no Apêndice. (Coelho, $1980)$.

\section{VALORES ESPERADOS}

R total do protocolo : Faixa de variação : 29 - 53

R monocromáticas : Faixa de variação : 12 - 22

$\mathrm{R}$ cromáticas : Faixa de variação : $17-31$

- Em relação à capacidade associativa, podemos observar em relação ao número de respostas;

\begin{tabular}{|c|c|c|}
\hline $\mathrm{n}^{\circ}$ respostas & Resultado & faixa de variação \\
\hline 7 & $63,64 \%$ & Média \\
\hline 4 & $36,36 \%$ & Abaixo \\
\hline
\end{tabular}


A maioria do grupo consegue interagir com o meio, percebendo-o.

- Quanto à relação das pranchas coloridas com as monocromáticas, obtivemos;

\begin{tabular}{|l|l|l|}
\hline Respostas & $\mathrm{n}^{\mathbf{o}}$ & $\%$ \\
\hline color $>$ mono & 10 & $91,91 \%$ \\
\hline color < mono & 01 & $9,09 \%$ \\
\hline
\end{tabular}

91, 91\% deram respostas color $>$ monocromática, revelando que o grupo reage frente à situações de maior apelo afetivo.

Observa-se que é o grupo que reage às situações afetivas, o que se espera de um grupo que necessita estar atento à dor e sofrimento dos pacientes e seus familiares.

\section{- NÍVEL DE OBSERVAÇÃO DA REALIDADE - TIPO DE PERCEPÇÃO: PERC}

Vamos considerar somente as respostas do Protocolo Total na medida em que, na análise das respostas das pranchas coloridas e das monocromáticas do grupo de profissionais, não encontramos grandes divergências que justificasse analisar as respostas separadamente do conjunto. Portanto, os valores esperados nas modalidades principais são os seguintes;

\begin{tabular}{|c|c|}
\hline & Faixa de variação em \% \\
\hline G & $13-29$ \\
\hline$P$ & $63-74$ \\
\hline$P$ & $5-11$ \\
\hline
\end{tabular}




\section{QUADRO 11 - PERCEPÇÃO DO GRUPO}

Fazendo uma síntese do quadro 11 temos:

\begin{tabular}{|c|c|c|c|}
\hline G\% & P\% & $\mathrm{p} \%$ & PERC \\
\hline $21,6 \%$ média & $59,45 \%$ abaixo & $2,70 \%$ abaixo & $\mathrm{G}(\mathrm{P})(\mathrm{p})$ \\
\hline $44,44 \%$ acima & $38,88 \%$ abaixo & - abaixo & $\mathrm{G} 3$ \\
\hline $37,93 \%$ acima & $55,17 \%$ abaixo & $3,44 \%$ abaixo & $\mathrm{G} 2(\mathrm{p})$ \\
\hline $20,68 \%$ média & $69,96 \%$ média & $10,34 \%$ média & $\mathrm{GPp}$ \\
\hline $42,16 \%$ acima & $39,58 \%$ abaixo & zero abaixo & $\mathrm{G} 2$ \\
\hline $16,66 \%$ média & $70,00 \%$ média & $10,00 \%$ média & $\mathrm{GPp}$ \\
\hline $50,00 \%$ acima & $20,00 \%$ abaixo & $13,33 \%$ acima & $\mathrm{G} 3 \mathrm{p} 1$ \\
\hline $38,43 \%$ acima & $42,75 \%$ abaixo & zero abaixo & $\mathrm{G} 2$ \\
\hline $26,00 \%$ média & $73,91 \%$ média & zero abaixo & GP \\
\hline $26,31 \%$ média & $63,15 \%$ média & zero abaixo & GP \\
\hline $20,68 \%$ média & $44,82 \%$ abaixo & $10,34 \%$ média & Gp \\
\hline
\end{tabular}

\begin{tabular}{|c|c|c|c|c|}
\hline G\% & P\% & P $\%$ & PERC & $\%$ \\
\hline média & abaixo & Abaixo & G(P)(p) & $9,09 \%$ \\
\hline acima & abaixo & Abaixo & G2 & $18,18 \%$ \\
\hline acima & abaixo & Abaixo & G2(p) & $9,09 \%$ \\
\hline acima & abaixo & Abaixo & G3 & $9,09 \%$ \\
\hline média & média & Média & GPp & $18,18 \%$ \\
\hline acima & abaixo & Acima & G3p1 & $9,09 \%$ \\
\hline média & média & Abaixo & GP & $18,18 \%$ \\
\hline média & abaixo & Média & Gp & $9,09 \%$ \\
\hline
\end{tabular}

Conforme a síntese do quadro 11, podemos observar que há $\mathrm{G}$ em todas as respostas em diferentes níveis, demonstrando que o grupo, como todo, demonstra captar o meio de modo amplo, em examinar o ambiente em sua totalidade e compreender as situações nos seus aspectos mais gerais. 
02 respostas (GPp), representando 18,18\% da amostra, estão dentro da média esperada, significando que estes profissionais, além de perceberem o ambiente como um todo, captam os aspectos mais ativos imediato e evidentes para a maioria das pessoas, como também a capacidade de captar os aspectos menos evidentes das situações .

O PERC equivalente a GP $(18,18 \%)$ reflete uma percepção ampla do ambiente, captando os aspectos mais evidentes, rotineiros e essenciais das situações, havendo prejuízo na análise e pesquisa mais detida dos fatos à medida em as minúcias das situações não são observadas.

$18,18 \%$ possuem o PERC equivalente a G2 e G3 respectivamente, que somando equivalem a 36,36\% da amostra, significando que estes profissionais percebem as experiências de modo genérico, evitando envolvimento direto na situação, têm dificuldade na observação dos dados práticos e evidentes da realidade.

O PERC $\mathrm{G}(\mathrm{P})(\mathrm{p})$, correspondente a 9,09\%, reflete uma percepção mais voltada para o meio percebendo os aspectos mais evidentes das situações. Porém, de modo restrito, os aspectos mais restritos são percebidos numa menor escala.

Nas respostas equivalentes a Gp (9,09\%), o meio é observado adequadamente e nas respostas G3p1 (9,09\%) o meio não é muito considerado, mas em ambas há uma percepção praticamente voltada para os detalhes menos óbvios, que são desapercebidos pela maioria. Por serem de profissionais atuando numa instituição médica, que visa a pesquisa e o ensino, e que o atendimento acaba refletindo estes dois objetivos, provavelmente trata-se de profissionais mais voltados para a pesquisa.

Vamos posteriormente relacionar o PERC com os outros propostos neste trabalho. 
- INDÍCES AFETIVO-EMOCIONAL

QUADRO 12 - Respostas de Cor (RC)

\begin{tabular}{|c|c|c|}
\hline $\mathrm{FC}>\mathrm{CF}+\mathrm{C}$ & $\mathrm{FC}<\mathrm{CF}+\mathrm{C}$ & $\mathrm{FC}=\mathrm{CF}+\mathrm{C}$ \\
\hline $2>0$ & 0 & 0 \\
\hline $2>0$ & 0 & 0 \\
\hline $2>1+0$ & 0 & 0 \\
\hline $2>1+0$ & 0 & 0 \\
\hline $4>0$ & 0 & 0 \\
\hline $3>0$ & 0 & 0 \\
\hline $2>0$ & 0 & 0 \\
\hline $2>1+0$ & 0 & $1=1+0$ \\
\hline 0 & 0 & $2=0+2$ \\
\hline 0 & 0 & \\
\hline $2>0$ & & \\
\hline
\end{tabular}

O grupo como um todo apresentou os seguintes índices;

\begin{tabular}{|c|c|}
\hline $\mathrm{FC}>\mathrm{CF}+\mathrm{C}$ & $81,82 \%$ \\
\hline $\mathrm{CF}<\mathrm{CF}+\mathrm{C}$ & $18,18 \%$ \\
\hline
\end{tabular}

$81,82 \%$ do grupo deram as respostas $\mathrm{FC}>\mathrm{CF}+\mathrm{C}$, o que mostra ser o grupo constituído, na sua maioria, de indivíduos amadurecidos, indicando flexibilidade na reação afetiva, ou seja, o grupo possui disponibilidade em manifestar seus afetos de modo adequado e espontâneo.

Esse resultado confirma dados das entrevistas,onde notamos a presença de sentimentos derivados do conflito entre as posições depressiva e paranóide (Tardivo, 1997), o que denota ser um grupo, de fato mais amadurecido.

As respostas $\mathrm{FC}<\mathrm{CF}+\mathrm{C}$, que equivalem a 18,18\% da amostra, refletem instabilidade emocional, a qual dependendo dos outros índices, pode refletir níveis de angústia e de sofrimento psíquico. 
QUADRO 13 - Respostas de Movimento ( RM )

\begin{tabular}{|c|c|c|c|}
\hline $\mathrm{M}$ & $>;<;=$ & $\mathrm{m}$ & $\mathrm{m}$ \\
\hline 2 & $=$ & 2 & 0 \\
\hline 5 & $>$ & 3 & 0 \\
\hline 1 & $<$ & 3 & 0 \\
\hline 0 & $<$ & 1 & 0 \\
\hline 5 & $=$ & 2 & 0 \\
\hline 1 & $>$ & 2 & 0 \\
\hline 2 & $>$ & 1 & 0 \\
\hline 4 & $>$ & 1 & 0 \\
\hline 2 & $<$ & 0 & 0 \\
\hline 2 & $>$ & 3 & 0 \\
\hline 0 & & & \\
\hline
\end{tabular}

O grupo apresentou:

\begin{tabular}{|c|c|c|}
\hline $\mathrm{M}>\mathrm{m}+\mathrm{m}^{\prime}$ & $\mathrm{M}<\mathrm{m}+\mathrm{m}^{\prime}$ & $\mathrm{M}=\mathrm{m}+\mathrm{m}{ }^{\prime}$ \\
\hline $45,46 \%$ & $27,27 \%$ & $27,27 \%$ \\
\hline
\end{tabular}

As respostas $M>m+m$ ' do grupo correspondem a 45,45\%, traduzindo ser uma parcela do grupo amadurecida, apresentando autonomia no sentido de definição de papéis claros; sentimentos de empatia, tendo como significado a capacidade de sentir e perceber o outro; auto-controle representando estabilidade interna e capacidade de adaptação refletida; de racionalização das emoções-revelando compreensão intelectual amadurecida de cada situação nova que se apresenta; auto aceitação no sentido dos profissionais terem perspectivas de vida e, por fim ,um grupo voltado a ser produtivo intelectualmente.

$\mathrm{O}$ restante do grupo, com respostas $\mathrm{M}$ menor ou igual indica que esta parcela do grupo apresenta sentimentos de insegurança, impotência, provavelmente 
vivenciando emoções e sentimentos difíceis de serem compreendidos e canalizados de uma maneira adequada.

Como em todos os índices, não podemos analisar estas respostas isoladamente, e mas sim ter claro o conjunto de respostas, para que se tenha uma perspectiva global dos dinamismos psíquicos.

De qualquer forma, é possível compreender as situações de sofrimento enfrentadas por esse grupo, conforme vimos na Introdução, pois estar diante da dor e do sofrimento desencadeados por enfermidades graves e crônicas como a ELA, sem prognóstico de cura, exigem muito do profissional.

Esslinger (2003) mostrou que os profissionais de saúde, que lidam com pacientes em estágio avançados de doença, não estão capacitados, em termos psicológicos, para lidar com suas próprias angústias e a dos pacientes trazidas pelo processo da morte. Ou seja, esse processo é compreensível e, ao lado de outros índices, revela a maturidade desse grupo. 


\section{Quadro 14 - ÍNDICE DE AFETIVIDADE/ ÍNDICE DE IMPULSIVIDADE}

\begin{tabular}{|c|c|}
\hline ÍNDICE DE AFETIVIDADE & ÍNDICE DE IMPULSIVIDADE \\
\hline $2,08 \%$ acima & $2,08 \%$ acima \\
\hline $1,40 \%$ média & $0,53 \%$ média \\
\hline $1,23 \%$ média & $0,75 \%$ acima \\
\hline $1,41 \%$ média & $1,00 \%$ acima \\
\hline $1,63 \%$ média & $0,77 \%$ acima \\
\hline $1,50 \%$ média & $0,45 \%$ média \\
\hline $1,40 \%$ média & $0,55 \%$ média \\
\hline $0,77 \%$ abaixo & $0,75 \%$ acima \\
\hline $1,87 \%$ acima & $0,87 \%$ acima \\
\hline $2,16 \%$ acima & $0,85 \%$ acima \\
\hline $2,22 \%$ acima & $1,25 \%$ acima \\
\hline
\end{tabular}

Índice de Afetividade - Média: 1,48

DP: 0,36

FAIXA DE VARIAÇÃO: $1,12-1.84$

Índice de Impulsividade - Média: 0,51

DP: 0,19

FAIXA DE VARIAÇÃO: 0,32 - 0,70

Em relação ao índice de afetividade e impulsividade, o grupo apresentou os seguintes resultados:

\begin{tabular}{|c|c|c|}
\hline Índice & Afetividade & Impulsividade \\
\hline Acima & $36,37 \%$ & $72,73 \%$ \\
\hline Média & $54,54 \%$ & $27,27 \%$ \\
\hline Abaixo & $9,09 \%$ & - \\
\hline
\end{tabular}


A partir do quadro acima verificamos que 54,55\% do grupo estudado encontra-se na média em relação ao índice de afetividade, traduzindo que a maior parte do grupo possui sensibilidade às estimulações afetivas do meio, enquanto uma pequena parte $(9,09 \% 0$ apresenta resultados abaixo da média, indicando dificuldades em reagir às solicitações afetivas do ambiente, talvez sugerindo sentimentos de impotência frente à realidade vivida.

Já 36,37\% apresenta-se acima da média, representando elevada sensibilidade aos estímulos afetivos do ambiente.

Como vimos na análise da Entrevista, o grupo apresenta sensibilidade à situação afetiva intensa desses pacientes. Para Balint (1975), a qualidade da relação com o paciente é determinante para que este se vincule ao tratamento. Dessa forma, essa sensibilidade é importante, pois, para esse autor, a postura mais sensível do médico em relação ao paciente (e nos referimos ao profissional de saúde de forma geral) faz com que a doença deixe de ser o eixo principal e para que o paciente, com sua história, sua vida, tome seu lugar.

O índice de impulsividade do grupo, em sua maioria, ficou acima da média $(72,73 \%)$. Este índice precisa ser analisado principalmente com as respostas de movimento humano (M) e respostas de forma - cor ( FC ). Parte significativa do grupo apresentou respostas $\mathrm{M}>\mathrm{m}+\mathrm{m}$ ' e $\mathrm{FC}>\mathrm{CF}+\mathrm{C}$ o que significa que este índice de impulsividade é considerado positivo pois está canalizado para o que chamamos de "garra" . 
QUADRO 15 - LIGAÇÃO EMOCIONAL AO AMBIENTE \% A

\begin{tabular}{|c|c|}
\hline MÉDIA \% & ACIMA \% \\
\hline 32,47 & 57,69 \\
\hline 36,11 & 66,66 \\
\hline 34,61 & 76,92 \\
\hline 29,16 & 47,36 \\
\hline 37,50 & 50,00 \\
\hline 37,78 & - \\
\hline
\end{tabular}

$$
\begin{gathered}
\text { \%A Protocolo Total : FAIXA DE VARIAÇÃO 28\% - 46\% } \\
\text { MÉDIA }=37,4 \quad \text { DP }=9
\end{gathered}
$$

Observamos que 54,55\% do grupo encontra-se na média, traduzindo que o grupo envolve-se emocionalmente com o meio de modo adequado, vinculando-se e percebendo as situações de modo amadurecido. Já 45,45\% do grupo encontra-se acima da média, revelando que parte do grupo reflete tensão emocional na ligação com o meio, na medida em que se envolve intensamente e de modo afetivo com as emoções.

Vimos aqui que a resposta afetiva do grupo ou é média ou acima da média, que confirma serem pessoas sensíveis á dor e ao sofrimento, o que, como vimos , é elemento essencial no atendimento ao paciente (Balint, 1975)

Por outro lado, o excesso de respostas afetivas ao meio pode indicar a situação de estresse a que profissionais como esses estão submetidos, como afirmou Kovacs (2003) ; Esslinger (2003) e Balint (1975). 


\section{QUADRO 16 - EQ; EQ' - TIPOS DE VIVÊNCIAS. CONFRONTO ENTRE OS ÍNDICES EQ E EQ'}

\begin{tabular}{|c|c|c|c|}
\hline EQ=M $\sum \mathrm{RC}$ & $\begin{array}{c}\text { TIPO VIVENCIAL } \\
\text { (nível manifesto) }\end{array}$ & EQ' $^{\prime}=\sum \mathrm{RM}: \sum \mathrm{RC}$ & Nível latente \\
\hline $2: \sum 1$ & INTROVERSIVO & $\sum 3: \sum 1$ & INTROVERSIVO \\
\hline $5: \sum 1$ & INTROVERSIVO & $\sum 5.5: \sum 1$ & INTROVERSIVO \\
\hline $1: \sum 2$ & EXTRATENSIVO & $\sum 3,5: \sum 2$ & INTROVERSIVO \\
\hline $0: \sum 3$ & EXTRATENSIVO & $\sum 1: \sum 3$ & EXTRATENSIVO \\
\hline $5: \sum 2$ & INTROVERSIVO & $\sum 4,5: \sum 2$ & INTROVERSIVO \\
\hline $1: \sum 1,5$ & EXTRATENSIVO & $\sum 2: \sum 1,5$ & INTROVERSIVO \\
\hline $2: \sum 1$ & INTROVERSIVO & $\sum 3: \sum 1$ & INTROVERSIVO \\
\hline $4: \sum 2$ & INTROVERSIVO & $\sum 3: \sum 2$ & INTROVERSIVO \\
\hline $2: \sum 1,5$ & INTROVERSIVO & $\sum 2: \sum 1,5$ & INTROVERSIVO \\
\hline $2: \sum 3$ & EXTRATENSIVO & $\sum 2: \sum 3$ & EXTRATENSIVO \\
\hline $3: \sum 1$ & INTROVERSIVO & $\sum 3: \sum 1$ & INTROVERSIVO \\
\hline
\end{tabular}

Em relação ao confronto entre os índices EQ e EQ’

\begin{tabular}{|c|c|}
\hline introversivo - introversivo & $63,64 \%$ \\
\hline extratensivo - introversivo & $18,18 \%$ \\
\hline extratensivo - extratensivo & $18.18 \%$ \\
\hline
\end{tabular}

Em relação aos tipos vivenciais, $63,63 \%$ do grupo apresenta o tipo introversivo, ou seja, a maioria do grupo tende a estabelecer relações profundas e significativas, selecionando as relações interpessoais, embora com restrições em se relacionar de modo mais amplo. $27,27 \%$ se apresenta como extroversivo, ou seja, parte do grupo é mais expansivo, relaciona-se mais facilmente, embora as relações estabelecidas sejam mais do nível social sem muitos comprometimentos. 
Um dado interessante mostra-se em 63,64\% do grupo, que têm uma relação de Eq e Eq' de introversivo-introversivo, refletindo estabilidade psíquica no que se refere aos aspectos manifestos e latentes da personalidade. Este dado confirma alguns dados anteriores de que este grupo está em consonância com o seu local de trabalho no sentido de ser uma instituição em que o estudo e a pesquisa são de extrema importância, e onde os atendimentos foram vistos de modo integrado e maduro.

Temos que $18,18 \%$ do grupo apresenta-se como extratensivo - extratensivo. Esta parcela de profissionais tem os aspectos manifestos e latentes extratensivos, provavelmente envolvendo-se mais emocionalmente com os atendimentos, conforma vimos anteriormente, a qual pode ser considerada uma condição necessária, desde que bem trabalhada, já que o excesso de envolvimento traz estresse e sobrecarga, (Kovacs, 2003).

Também 18,18\% do grupo mostra-se extratensivo - introversivo, denotando estabilidade emocional, pois embora os aspectos manifestos revelem-se vinculados ao meio ambiente, em termos intra - psíquicos estes profissionais se preservam, não ficando muito expostos às variáveis externas.

De forma geral a análise dos índices de Rorschach apontaram para um grupo em grande parte amadurecido, e com sensibilidade afetiva à situação de trabalho e de contato com a dor e sofrimento de seus pacientes. Esses dados vêm confirmar, de forma geral o que observamos na análise da Entrevista e corroboram dados encontrados por outros autores citados na Introdução.

Vale ainda destacar a natureza desses dois instrumentos que buscam mudar aspectos conscientes e conhecidos e também de aspectos latentes e inconscientes. Nestes, evidenciaram-se aspectos muito positivos e, também, conforme discutimos, aspectos de estresse, dor e sofrimento a que também os profissionais estão submetidos 


\subsection{QUESTONÁRIO DE QUALIDADE DE VIDA DE MCGILL}

Consideramos importante, avaliar cada parte do questionário Qualidade de Vida, no sentido de verificarmos a média nos diversos aspectos avaliados por esse instrumento. Mantemos a forma de apresentação de todo o grupo, conforme responderam às 16 questões que compõem as três partes do questionário .(inserido em anexo

Assim, os quadros a seguir referem-se a cada pergunta, numa escala de 0 a 10, com a resposta de cada profissional dentro desta escala.

Na PARTE A - em relação a todos os aspectos; físico, emocional, social, espiritual e financeiro nos dois últimos dias. Minha vida foi;

Muito ruim (0) excelente (10)

\begin{tabular}{|l|l|l|l|l|l|l|l|l|l|l|}
\hline 07 & 07 & 08 & 10 & 08 & 05 & 03 & 08 & 08 & 09 & 09 \\
\hline
\end{tabular}

\begin{tabular}{|c|c|c|}
\hline $\mathrm{n}^{\text {o de profissionais }}$ & Pontuação na escala & $\%$ \\
\hline 01 & 03 & $9,09 \%$ \\
\hline 01 & 05 & $9,09 \%$ \\
\hline 02 & 07 & $18,18 \%$ \\
\hline 04 & 08 & $36,37 \%$ \\
\hline 02 & 09 & $18,18 \%$ \\
\hline 01 & 10 & $9,09 \%$ \\
\hline Total 11 & Média 7,45 & $100 \%$ \\
\hline
\end{tabular}

A média do grupo encontra-se entre 7 e 8 na escala, representando $81,82 \%$ dos profissionais que consideraram sua qualidade de vida em todos os aspectos, de bom para excelente. E $18,18 \%$ do grupo encontra-se entre 03 e 05 , ou seja, de regular para ruim. 
PARTE B - Sintomas Físicos ou Problemas Físicos

Nos dois últimos 02 dias um sintoma difícil tem sido, ( 03 sintomas )

Sem problema ( 0 ) com problema ( 10 )

\begin{tabular}{|c|c|c|c|c|c|c|c|c|c|c|c|}
\hline$(1)$ & 05 & 03 & 05 & 10 & 05 & 05 & 06 & 03 & 04 & 10 & 06 \\
\hline$(2)$ & 04 & 0 & 06 & 10 & 06 & 0 & 06 & 04 & 04 & 05 & 07 \\
\hline$(3)$ & 0 & 0 & 0 & 05 & 04 & 0 & 0 & 03 & 07 & 03 & 0 \\
\hline
\end{tabular}

(1) Em relação ao primeiro sintoma difícil; 07 profissionais ficaram entre 0 e 05 na escala $(63,63 \%$ ) e 04 profissionais ficaram entre 06 e 10 ( $36,36 \%)$. Os sintomas citados foram; dores de cabeça, dores articulares, dores de estômago, cansaço, tristeza, fadiga, intestino preso, angústia e ansiedade.

(2) Em relação ao segundo sintoma difícil; 06 profissionais ficaram entre $0 \mathrm{e}$ 5 na escala $(54,54 \%)$ e 04 profissionais entre 06 e $10(36,36 \%)$.Os sintomas citados foram; dormir pouco, cansaço, ansiedade.

(3) Em relação ao terceiro sintoma; 10 profissionais ( $91 \%$ ) ficaram entre $0 \mathrm{e}$ 05 e 01 profissional entre 06 e 10 (9,09\%). Como respostas: ausência de sintomas, TPM, ansiedade, solidão, insônia.

Fisicamente terrível ( 0 )

fisicamente bem ( 10 )

\begin{tabular}{|l|l|l|l|l|l|l|l|l|l|l|}
\hline 08 & 08 & 08 & 05 & 05 & 06 & 05 & 04 & 05 & 10 & 08 \\
\hline
\end{tabular}

$5(45,45 \%)$ profissionais estão entre 0 e 05 e 6 profissionais $(54,55 \%)$ entre 6 e 10.

Podemos observar que nas respostas em que os profissionais foram solicitados a relatar três sintomas físicos que sentiram nos dois últimos dias, ficaram entre 0 e 5 o que significa ausência de problema ( sem problema)

Porém, quando foram relatar os sintomas, o grupo todo relatou dores, falta de sono, ansiedade e outros.

$\mathrm{Na}$ resposta seguinte, a maior parte do grupo respondeu que se sentem fisicamente bem. 
Assim, observamos uma ambivalência nesse grupo sem se dizer como estando bem, e, ao mesmo tempo, respondendo e denotando sintomas como dores, ansiedade e falta de sono.

Podemos verificar aqui, conforme já observado nos outros instrumentos, que o grupo, mesmo se apresentando bem, é sensível e muitos, de fato, denotam estresse e alguma dificuldade, o que é de se esperar em profissionais que lidam com pacientes com doenças como a ELA (Esslinger, 2003, e Kovacs, 2003).

PARTE C - Sentimentos e Pensamentos

Questão 05 - tenho me sentido deprimido

De forma alguma ( 0 ) extremamente ( 10 )

\begin{tabular}{|l|l|l|l|l|l|l|l|l|l|l|}
\hline 0 & 0 & 0 & 04 & 04 & 0 & 0 & 03 & 03 & 0 & 0 \\
\hline
\end{tabular}

$100 \%$ ficaram entre 0 e 5 .

Questão 06 - Tenho estado nervoso ou preocupado

De forma alguma ( 0 ) extremamente ( 10 )

\begin{tabular}{|c|c|c|c|c|c|c|c|c|c|c|}
\hline 04 & 03 & 03 & 10 & 03 & 05 & 05 & 05 & 04 & 04 & 0 \\
\hline
\end{tabular}
ficaram entre 0 e 05 .

Questão 07 - quanto tempo você se sentiu triste? Nunca ( 0 ) sempre ( 10$)$

\begin{tabular}{|l|l|l|l|l|l|l|l|l|l|l|}
\hline 0 & 03 & 0 & 05 & 04 & 0 & 0 & 03 & 03 & 04 & 04 \\
\hline
\end{tabular}

$100 \%$ ficaram entre 0 e 5 . 
Questão 08 - quando eu pensava no futuro eu estava; sem medo ( 0$)$ com medo( 10$)$

\begin{tabular}{|l|l|l|l|l|l|l|l|l|l|l|}
\hline 0 & 03 & 0 & 09 & 0 & 03 & 04 & 0 & 05 & 03 & 04 \\
\hline
\end{tabular}

10 profissionais ( 90,90\% ) ficaram entre 0 e 5 e 1 profissional $(9,09 \%)$ entre 6 e 10.

Questão 09 - minha vida tem sido;

sem significado ( 0 )

com significado( 10 )

\begin{tabular}{|l|l|l|l|l|l|l|l|l|l|l|}
\hline 10 & 07 & 10 & 10 & 08 & 10 & 08 & 08 & 10 & 10 & 08 \\
\hline
\end{tabular}

$100 \%$ ficaram entre 6 e 10.

Questão 10 - em relação a alcançar os objetivos, eu tenho;

Feito nenhum progresso ( 0) progredido para completa realização(10)

\begin{tabular}{|l|l|l|l|l|l|l|l|l|l|l|}
\hline 06 & 06 & 10 & 06 & 10 & 10 & 08 & 08 & 07 & 08 & 10 \\
\hline
\end{tabular}

$100 \%$ dos profissionais ficaram entre 6 e 10 na escala.

Questão 11 - minha vida tem sido;

Completamente sem valor $(0)$ muito válida( 10 )

\begin{tabular}{|l|l|l|l|l|l|l|l|l|l|l|}
\hline 10 & 08 & 10 & 08 & 06 & 10 & 10 & 08 & 10 & 10 & 08 \\
\hline
\end{tabular}

$100 \%$ dos profissionais ficaram entre 6 e 10 na escala.

Questão 12 - eu tenho sentido que possuo;

Nenhum controle sobre minha vida $(0)$

completo controle(10)

\begin{tabular}{|l|l|l|l|l|l|l|l|l|l|l|}
\hline 08 & 06 & 10 & 08 & 09 & 09 & 10 & 08 & 08 & 08 & 09 \\
\hline
\end{tabular}

$100 \%$ dos profissionais ficaram entre 6 e 10 na escala.

Questão 13 - eu me senti bem sobre mim mesmo como pessoa;

Discordo completamente ( 0 ) concordo ( 10$)$

\begin{tabular}{|l|l|l|l|l|l|l|l|l|l|l|}
\hline 04 & 03 & 10 & 0 & 05 & 05 & 02 & 03 & 05 & 03 & 08 \\
\hline
\end{tabular}

09 profissionais $(81,81 \%)$ ficaram entre 0 e 5 e 02 profissionais $(18,19 \%)$ entre 6 e 10 . 
Questão 14 - os últimos dois dias foram;

Um peso ( 0 )

uma dádiva( 10$)$

\begin{tabular}{|l|l|l|l|l|l|l|l|l|l|l|}
\hline 08 & 08 & 10 & 10 & 06 & 10 & 08 & 07 & 10 & 10 & 10 \\
\hline
\end{tabular}

$100 \%$ dos profissionais ficaram entre 6 e 10 .

Questão 15 - o mundo tem sido;

Um lugar impessoal e cruel (0) cuidadoso e atende minhas necessidades(10)

\begin{tabular}{|l|l|l|l|l|l|l|l|l|l|l|}
\hline 06 & 05 & 09 & 05 & 03 & 09 & 08 & 06 & 10 & 08 & 06 \\
\hline
\end{tabular}

07 profissionais ( 63,63\%) ficaram entre 6 e 10 na escala e 03 profissionais ( $27,27 \%$ ) na escala entre 0 e 5.

Questão 16 - eu tenho me sentido apoiado;

De forma alguma ( 0 )

completamente( 10$)$

\begin{tabular}{|l|l|l|l|l|l|l|l|l|l|l|}
\hline 06 & 03 & 07 & 07 & 0 & 06 & 08 & 05 & 05 & 08 & 10 \\
\hline
\end{tabular}

04 profissionais ( $36,36 \%$ ) ficaram entre 0 e 5 na escala e 07 profissionais ( $63,63 \%$ ) ficaram entre 6 e 10.

Por esses dados, há alguma coincidência com os dados da entrevista. Porém de forma geral, o grupo respondeu no que diz respeito aos sentimentos e pensamentos, de forma diversa do Rorschach.

Vale destacar que esse instrumento se refere a aspectos mais manifestos e conhecidos e o Método de Rorschach, como já apontamos abrange a personalidade como um todo, incluindo os aspectos latentes do sujeito.

Avaliando as respostas, segundo os critérios de McGill, a média do grupo foi de 6,75, de uma escala de 0 a 10,ou seja, na faixa de regular para bom.

Esta média assinala que os profissionais mostram-se estáveis em todos os seus aspectos vida.

Estes resultados não coincidem totalmente com os obtidos nas entrevistas e nos resultados do Rorschach.

Vale considerar a diferença dos instrumentos, bem como a condição de profissionais de saúde apresentarem-se bem, uma vez que nas respostas do 
questionário de Qualidade de Vida revelam os aspectos manifestos e de adaptação ao meio. 


\section{CAPÍTULO V - SÍNTESE E CONSIDERAÇÕES FINAIS}

O grupo de profissionais que cuida de pacientes com ELA, seus respectivos cuidadores e familiares, consegue manter-se como grupo coeso, mesmo considerando suas diferenças, em função de algumas importantes variáveis, sendo que uma das principais foram os resultados obtidos no quadro 1, referente à escolha da profissão, em que a maioria dos profissionais de saúde encontram-se satisfeitos com suas expectativas atendidas. Este dado é reforçado pela média de permanência dos profissionais no ambulatório da Neuromuscular e no atendimento aos pacientes, que é em média de 06 anos. A maior parte do grupo permanece no Ambulatório da Neuromuscular, atendendo os pacientes com ELA, mesmo depois de concluírem seus cursos de especialização, mestrado ou doutorado, havendo ainda profissionais que só mantêm vínculo de atendimento como voluntários. A grande maioria escolheu a profissão por querer ajudar o próximo e atender pessoas em estado de sofrimento. Esta realização vai, sem dúvida, repercutir no relacionamento com os pacientes, em várias dimensões, as quais puderam ser observadas com os resultados das entrevistas.

É um grupo que mesmo estando bem em seu trabalho demonstram sentimentos de frustração, ansiedade, raiva, de sentirem-se ameaçados, cobrados e tristes com questões referentes à falta de recursos para o atendimento; o contato com o paciente em falar do diagnóstico de ELA; e outras questões que, na sua maioria relacionam-se com o paciente. Observamos assim defesas como racionalização e algumas vezes de negação como forma de dar conta dessa demanda de sofrimento, pois muitas vezes os profissionais se ressentem de não poderem resolver questões que estão fora de alcance deles.

Destacamos os sentimentos dos profissionais ao sentirem-se felizes, amparados e recompensados com as respostas de melhora do paciente, adesão ao tratamento, amizade e reconhecimento dos familiares dos pacientes. Estas respostas estão relacionadas aos objetivos explícitos relacionados ao plano de trabalho consciente a atuação técnica, quanto aos implícitos, referentes às motivações inconscientes de gratificação. O conjunto das respostas, e os resultados apresentados revelaram que os profissionais construíram imagens diferentes em relação aos 
pacientes, cuidadores e os próprios colegas de trabalho, por meio de percepção subjetiva que cada um estabelece com seus pacientes e com o grupo.

Para Zimerman( 2000) confirma esta constatação, pois segundo ele, os aspectos da personalidade do médico, estendendo esta análise para os profissionais de saúde, podem influenciar o vínculo estabelecido com o paciente.As características de personalidade de cada profissional, somadas aos conhecimentos e habilidades específicas, irão definir o modelo de atendimento. Este modelo é que irá definir a relação do profissional com o paciente, estabelecendo-se uma relação recíproca em que atuam a transferência e a contratransferência

Estas diferentes percepções ficaram evidenciadas no quadro 11 onde há profissionais que captam o meio de modo amplo, incluindo as situações coditianas com seus detalhes; profissionais que captam as situações de modo geral, não vinculando as questões mais de ordem práticas, e aqueles que só observam detalhes, desvinculados do contexto mais geral. Pelo tipo de percepção podemos notar o quanto o grupo é diversificado em sua vinculação com os pacientes.

Porém,embora haja esta diversificação nas percepções do meio e consequentemente dos pacientes e das relações que são estabelecidas, trata-se de um grupo afetivo, maduro, cuja impulsividade está canalizada basicamente para o aperfeiçoamento profissional.

As respostas de $\mathrm{FC}$ do grupo são em número superior as respostas de $\mathrm{CF}$ e $\mathrm{C}$, o que segundo Silveira mostra sensibilidade em perceber o estímulo afetivo associando a algum significado, traduzindo-se isso em amadurecimento psicológico, adaptação social e estilo pessoal de pensamento.

As respostas de movimento humano também são superiores as de movimento animal e movimento subjetivo, que segundo Coelho( 2007 ) têm em si a de perceber e sentir os outros através dos próprios sentimentos e percepções.

Tanto as respostas de cor como as de movimento conferem que uma parcela considerável do grupo tem sensibilidade em captar o sofrimento do paciente, o que com certeza reflete-se na relação em termos de continência, apoio e contra tranferencialmente o paciente vê $=$ se atendido em sua necessidades.

A maior parte do grupo é de profissionais com tipo de vivências introversivas, tanto em nível manifesto como latente e a outra parte do grupo com vivências do tipo 
extroversivo. Vemos aí uma diferença profunda no lidar com os pacientes; uma parcela com objetivos de pesquisa e de investigação e outra parcela que tem como objetivo principal, o atendimento propriamente dito, mas a maioria se vinculando afetivamente aos pacientes e seus familiares.

Os profissionais com percepção mais ampla e atento às situações rotineiras, provavelmente estabelecem relações mais sensíveis ao perceber o sofrimento e necessidade do outro, possibilitando-lhes ter uma visão global do paciente, e dar atenção aos aspectos mais subjetivos. Em contrapartida, provavelmente o paciente irá responder mais positivamente a esta relação de modo a colaborar com o tratamento e as demandas inerentes do processo de adoecimento.

Os profissionais com percepção mais restrita aos detalhes e que observam o ambiente sem se deter nas situações, são profissionais que possuem uma visão parcial do paciente, focando sua atenção em aspectos mais voltados para a pesquisa e investigação.

Quando Romano( 1999) analisa que a doença é revestida de significados únicos para cada indivíduo, estamos falando não só do paciente mas também do profissional de saúde que lida com seus pacientes, em nossa pesquisa especificamente os pacientes com ELA.

Encontramos algumas respostas do tipo "nunca senti tristeza", "nunca me deprimi" e outras, tanto na entrevista como no questionário de Qualidade de Vida, revelam a presença de mecanismos de defesas como modo de darem conta de situações que demandam grande mobilidade psíquica. Rocco( 1992) confirma estes resultados ao afirmar que as experiências do adoecer põem em jogo mecanismos inconscientes de adaptação, regressão, negação e racionalização,

Nas respostas do questionário de vida fica claro a presença de mecanismos de defesas por parte dos profissionais, mas acreditamos que estes são necessários não só para lidar com a questão do sofrimento, como também como forma de manter o grupo coeso em torno de um mesmo objetivo que é o de trabalhar com pacientes portadores de ELA. Esta hipótese é reforçada pelas autoras Seide e Zannom( 2004) quando afirmam que os questionários de qualidade de vida têm como função verificar o momento atual da pessoa e como ela esta lidando com as situações. 
Podemos concluir que os objetivos que tínhamos foram alcançados nesse estudo. Trata-se de um grupo amadurecido, sensível a dor e ao sofrimento do outro, especificamente do paciente, com respostas que denotam afetividade, frustração diante da falta de cura e sucesso no tratamento.

A qualidade de vida encontra-se preservada, e os dados confirmam que, apesar das dificuldades inerentes em se trabalhar numa instituição, sentem-se realizados em seus trabalhos.

Pelo conjunto de respostas ficou claro a necessidade dos profissionais terem um suporte social, que Campos ( 2005) define como meio de preservar a integridade psíquica dos mesmos.

Concluímos esse trabalho, recomendando se pensar na implantação de um programa de saúde mental, que dê sustentação emocional aos profissionais de saúde, como meio de lidarem com seu trabalho de maneira menos ansiosa e sofrida ,o que irá refletir com certeza, de modo positivo na relação com os pacientes com ELA, seus familiares e cuidadores. 


\section{REFERÊNCIAS}

ABREU FILHO, A.G.; STEINER, A.L.; TARDIVO, L.S.P.C.; SILVA, H.C. Manifestações do sofrimento humano: avaliação, compreensão e formas de intervenção: cuidadores e pacientes com esclerose lateral amiotrófica (ELA). Estudo compreensivo e suporte emocional. In: TARDIVO; L.S..P.C; GIL; C. A. et al Anais da Jornada Apoiar: proposta de atendimento. Laboratório de Saúde Mental e Psicologia Clínica Social do Instituto de Psicologia da Universidade de São Paulo, São Paulo, 2003.

ADRADOS. Teoria e Prática do Teste de Rorschach. Ed. Vozes, Petrópolis, 1980.

ASSOCIAÇÃO BRASILEIRA DE ESCLEROSE LATERAL AMIOTRÓFICA. ABRELA: Manual de Informação: referência - elaboração. São Paulo, 2007.

BALINT,M. O médico, seu paciente e a doença. Rio de Janeiro: Atheneu,2005.

BARUS-MICHEL, J. - -Bulletin de psychologie v. 54 (2) 452 março-abril 2001.

BELLODI. O Clínico e o Cirurgião: Estereotipo, personalidade e escolha da especialidade médica.São Paulo:Casa do Psicólogo,2001.

BLEGER, J. Temas em psicologia: entrevista e grupos. 3 ed - São Paulo: Martins Fontes, 2007.

BLEGER,J. Psico- Higiene e Psicologia Institucional.Porto Alegre,Artes Médicas, 1984.

BOTEGA, N.J. Psicologia Médica, Balint...Lembra-se? Monitor Psiquiátrico v.2,p.1-2,1996. 
CAMPOS,E. Quem cuida do cuidador: uma proposta para os profissionais de saúde. $2^{\circ}$ edição. Petrópolis,RJ: Vozes,2005

CAPRARA, A. SILVA F., A relação paciente-médico: Para uma humanização da prática médica.Cadernos de Saúde Pública, v.15,n.3,1995.

CARDOSO, R.R.M.S. Emoções que adoecem.São Paulo:Vetor, 2006.

CASADO,L.P.Avaliação do Equilíbrio das Forças Subjetivas:Eq e Eq'.In: COELHO e colab.Rorschach Clínico:Manual Básico.São Paulo: Terceira Margem,2000.

COELHO,L. Epilepsia e personalidade: psicodiagnóstico de Rorschach, entrevista e anamnese heredológica em 102 examinandos. $2^{\circ}$ edição,.São Paulo, Àtica, 1980.

COELHO, L e colaboradores. Rorschach Clinico: Manual Básico. São Paulo: Terceira Margem,2000

COELHO. L e colaboradores. Rorschach Clinico: Manuel Básico. Sào Paulo: Terceira Margem,2007

DUARTE.S e CICONELLI.R.M. Instrumentos para a Avaliação da Qualidade de Vida: Genéricos e Específicos.In:DINIZ DENISE PARÁ,SCHOR NESTOR, Guia de Qualidade de Vida.Barueri,São Paulo:Manole,2006

ESSLINGER,I. O paciente, a equipe de saúde e o cuidador: De quem é a vida afinal? Um estudo acerca do morrer com dignidade. O mundo da Saúde, ano 27,v.27,n.3: 373-382,2003. 
ETCHEGOYEN,R.H. Fundamentos da Técnca psicanalítica.Porto Alegre: Artimed Editora, 2004.

PIÉRON,H. Dicionário de Psicologia.Porto Alegre:Editora Globo,1966.

FREUD, Anna. O Ego e os mecanismos de defesa. Porto Alegre: Artmed,2006. ( Original publicado em 1936).

Freud,S. As perspectivas futuras da terapia psicanalítica. In: Edição Standard Brasileira das Obras Psicológicas completas de Sigmund Freud.Rio de Janeiro: Imago,1987 .v.11 (Original publicado em 1910-1909). As neuropsicoses de Defesa 1824 vol. 3 p 57 e 59. Inibições, Sintomas e Ansiedade 1926 v 20 p 199.

FIGUEIRA, colaboradores. Contransferência: de Freud aos contemporâneos. São Paulo: Casa do Psicólogo, 1994.

GABBARD,G. Psiquiatria psicodinâmica: baseado no DSM-IV.Porto Alegre:Artmed,1998.

HAG,I. et al. "Psycosocial aspects of dialysis and renal transplant". J.Pak.Med.Ass.41:99-100,1991

JEAMMET,P.,REYNAUD,M.,CONSOLI,S.,Psicologia Médica.Rio de Janeiro: Masson, 1982.

KAES,R. A Instituição e as insituições: estudo psicanalítico.São Paulo.Casa do Psicólogo,1991.

KOVÁCS, e colaboradores Morte e desenvolvimento humano. $4^{\circ}$ ed.São Paulo.Casa do Psicólogo.2002 
KUBLE - Ross, E. Sobre a morte e o morrer. São Paulo: Martins Fontes, 1987.

KUSNETZOFF, J.C., Introdução à psicopatologia psicanalítica - Rio de Janeiro: Nova Fronteira, 1982.

LAGACHE,D. Definição encontrada no verbete sobre frustração. In: PIÉRON HENRI, Dicionário de Psicologia - Rio de Janeiro; Editora Globo,1996.

LUDKE,M. e ANDRÉ,M.e.D.,Pesquisa em Educação: abordagens qualitativas. São Paulo, E.P.U.,1986

NOGUEIRA-MARTINS,L.A..Sofrimento Psíquico e Estresse Ocupacional em Estudantes e Profissionais as Área da Saúde. In:DINIZ DENISE PARÁ,SCHOR NESTOR, Guia de Qualidade de Vida.Barueri,São Paulo:Manole,2006

OLIVEIRA,A.S.B.;SILVA,H.C.A. Resumo do 13 Simpósio Internacional sobre Esclerose Lateral Amiotrófica.Melbourne- Austrália,2002

PEDROSA,M.A. Reflexões sobre Michael Balint comunicando uma experiência de grupos.In: MELLO FILHO,J.Psicossomática hoje.Porto Alegre,Artes Médicas,1992.

RAMIREZ-TOGNOLA,C.Fadiga na esclerose lateral amiotrófica: frequiência e fatores associados. São Paulo, 2004.Dissertação, (Mestrado) - Faculdade de Medicina, Universidade de São Paulo.

ROCCO,R.P., Relação estudante de Medicina-paciente In: MELLO FILHO, J.Psicossomática hoje.Porto Alegre,Artes Médicas,1992.

ROMANO,B.W., Princípios para a prática da Psicologia Clínica em hospitais. São Paulo,Casa do Psicólogo,1999. 
PELLINI, M.C.B.M. Avaliação psicológica para porte de arma de fogo: Contribuições da prova de Rorschach, Casa do Psicólogo, 2000.

RORSCHACH,H..Psicodiagnóstico . São Paulo.Ed. Mestre Jou, 1974.

SANCOVSKI, A.R. Efeitos da visita médica nos pacientes da enfermaria da Clínica Geral do Hospital das Clínicas da Faculdade de Medicina da Universidade de São Paulo.São Paulo,2002.Tese de Doutorado - Faculdade de Medicina,Universidade de São Paulo.

SANTOS, G.A., método de Rorschach: Atores e Temas da Produção Científica do Brasil IN iv Congresso Nacional da Associação Brasileira de Rorschach e Métodos projetivos . 2006; Brasília

SEIDE, E. and ZANNON,C. Qualidade de vida e saúde:aspectos conceituais e metodológicos. Cadernos de SAÚDE Pública, vol20 no2.R.J. Mar/Apr.2004

SPITZ, D.T. As reações psicológicas á saúde e ao adoecer. In :Saúde Mental no Hospital Geral. Cadernos IPUB.V.1,n¹.Instituto de Psiquiatria da UFRJ,1997.

TARDIVO, L.S.P.C. O adolescente e sofrimento emocional nos dias de hoje: reflexões psicológicas - encontros e viagens. Tese(livre docência) - Instituto de Psicologia da Universidade de São Paulo,2004

TARDIVO, L. S. L. P. C; ABREU FILHO, A.G.; STEINER, A.L., SILVA, H. C. In: Anais - Jornada Apoiar: Propostas de Atendimento., 2003 São Paulo. Anais - Jornada Apoiar: Propostas de Atendimento., 2003. V.1.p. 72-80.

TARDIVO, L.S.P.C. e GIL, CA - Anais da III Jornada APOIAR-Atendimentos Clínico Diferenciado e Inclusão: O papel da psicologia Clinica Social, Laboratório de Saúde Mental e Psicologia Clínica Social,Instituto de Psicologia da Universidade de São Paulo -São Paulo,2005 
TARDIVO, L.S.P.C. O adolescente e sofrimento emocional nos dias de hoje.São Paulo: Vetor,2007

TURATO, E.R. - Tratamento da metodologia da pesquisa clínico-qualitativa: construção teórico-epistemológico, discussão comparada e aplicação nas áreas de saúde e humanas - 2ed.Petrópolis, Vozes, out/2003.

TURREL, A.apud ROCCO, R.P. Psicossomática hoje. In: MELO FILHO, J. Relação estudante de medicina-paciente. Porto Alegre, Artes Médicas, 1992.

SILVEIRA, A. Prova de Rorschach: elaboração do psicograma. Ed. Brasileira, 1985.

VAZ, C., O Rorschach: teoria e desempenho, $3^{\circ}$ edição, Ed. Manole Ltda, São Paulo.

WINNICOTT, Explorações Psicanalíticas: D.W.Winnicott Clare Winnicott,Ray Shephepherd \& Madeleine Davis;Trad.:José Ocyavio de Aguiar Abreu - Porto Alegre:Artes Médicas Sul,1994

ZIMERMAN,D.E. A formação psicológica do médico .In: MELLO FILHO,J. Psicossomática Hoje. Porto Alegre: Artes Médicas, 1992.

ZIMERMAN, D.E. Velhice: Aspectos biopsicossociais. Porto Alegre: Artes MÉDICAS, 2000. 


\section{ANEXO 1 \\ TERMO DE CONSENTIMENTO LIVRE E ESCLARECIDO}

1- Título do projeto: Aspectos Psicológicos de Qualidade de Vida dos Profissionais de Saúde na relação com os pacientes portadores de Esclerose Lateral Amiotrófica - (ELA) - um Estudo Compreensivo.

2- O objetivo deste estudo é compreender os aspectos psicológicos e de qualidade de vida que estão presentes no atendimento do profissional de saúde com o paciente portador de ELA, assim como procurar entender de que maneira esses lidam com a dor e sofrimento desses pacientes, familiares.

3- Para tanto, serão utilizados:

3.1 entrevista psicológica estruturada com o objetivo de levantar os dados pessoais e de situar o profissional dentro de seu contexto de trabalho.

3.2 aplicação do questionário Qualidade de Vida McGill para ver sua eficácia em pessoa não doente no que se refere a auxiliar no planejamento de ações no trabalho

3.3 o Teste de Rorschach . O Teste de Rorschach consta de dez pranchas , com manchas. Será solicitado que o profissional fale o que está vendo em cada prancha. A finalidade não é de psicodiagnóstico e sim de compreender alguns aspectos afetivos e emocionais que possam interferir na relação profissional - paciente. Os benefícios para os participantes será a possível contribuição para uma reflexão e aprimoramento nas relações interpessoais com os pacientes, familiares e cuidadores, a medida que haverá devolutiva dos resultados. Estas devolutivas serão dadas de modo sigiloso e individual .

4- Garantia de acesso: Em qualquer etapa do estudo, o profissional terá acesso ao responsável pela pesquisa para esclarecimento de eventuais dúvidas. O principal investigador é a psicóloga Ana Luiza de Figueiredo Steiner, que pode ser encontrado no Ambulatório Neuromuscular do Hospital São Paulo / UNIFESP , à rua Pedro de Toledo , n⿳377, Vila Clementino, telefone(11) 5575-59-02. Se houver alguma consideração ou dúvida sobre a ética da pesquisa, entrar em contato com o Comitê de ética em Pesquisa (CEP) - ua Botucatu , $572-1^{\circ}$ andar cj 14, 5571-1062 FAX: 5539-7162 - E-mail: cepunifesp@epm.br

5- É garantida a liberdade da retirada de consentimento a qualquer momento e deixar de participar do estudo, sem qualquer prejuízo à instituição;

6- Direito de confidencialidade - As informações obtidas serão analisadas individualmente e quando em conjunto com outros profissionais, não será divulgado a identificado de nenhum profissional em nenhuma hipótese. 
7- Direito de ser mantido atualizado de resultados que sejam do conhecimento dos pesquisadores;

8- Despesas e compensações: não há despesas pessoais para o participante em qualquer fase do estudo. Também não há compensação financeira relacionada á sua participação. Se existir qualquer despesa adicional, ela será absorvida pelo orçamento da pesquisa.

9- Em caso de dano pessoal, diretamente causado pelos procedimentos propostos neste estudo (nexo casal comprovado), o participante tem direito as indenizações legalmente estabelecidas.

10- Compromisso do pesquisador de utilizar os dados coletados somente para esta pesquisa.

11- Acredito ter sido suficientemente informado a respeito das informações que li ou que foram lidas para mim, descrevendo o estudo "Aspectos Psicológicos de Qualidade de Vida dos Profissionais de Saúde na relação com os pacientes portadores de Esclerose Lateral Amiotrófica - (ELA) - um Estudo Compreensivo".

Eu discuti com a psicóloga Ana Luiza de Figueiredo Steiner sobre a minha decisão em participar nesse estudo. Ficaram claros para mim quais são os propósitos do estudo, os procedimentos a serem realizados, as garantias de confidencialidade e de esclarecimentos permanentes .Ficou claro também que minha participação é isenta de despesas. Concordo voluntariamente em participar deste estudo e poderei retirar o meu consentimento a qualquer momento, antes ou durante o mesmo, sem penalidades ou prejuízo ou perda de qualquer benefício que possa ter adquirido, ou no meu entendimento neste Serviço.

Assinatura do representante legal

Data_I_ I

Assinatura da testemunha

Data_l_l_

Assinatura do responsável pelo estudo

Data_I___ 


\section{ANEXO 2}

$\operatorname{IImo(a).~Sr(a).~}$

Pesquisador(a) ANA LUIZA DE FIGUEIREDO STEINER

Co-Investigadores: Acary Souza Bulle Oliveira; Helga Cristina de Almeida Silva; Leila De La Plata Tardivo

Disciplina/Departamento: Neurologia Clínica/Neurologia e Neurocirurgia da Universidade Federal de São Paulo/Hospital São Paulo

Patrocinador: Recursos Próprios.

\section{PARECER DO COMITÊ DE ÉTICA INSTITUCIONAL}

Ref: Projeto de pesquisa intitulado: “Aspectos psicológicos e de qualidade de vida dos profissionais de saúde na relação com os pacientes portadores de esclerose lateral amiotrófica - (ELA) - um estudo compreensivo".

CARACTERÍSTICA PRINCIPAL DO ESTUDO: Estudo clínico observacional, entrevistas.

RISCOS ADICIONAIS PARA O PACIENTE: sem risco, desconforto mínimo, nenhum procedimento invasivo.

OBJETIVOS: Compreender os aspectos psicológicos e de qualidade de vida que estão presentes no atendimento do profissional de saúde com o paciente portador de ELA, assim como procurar entender de que maneira estes lidam com a dor e sofrimento destes pacientes, cuidadores e familiares.

RESUMO: Os participantes estudados serão multiprofissionais da área de saúde que atendem os pacientes portadores de ELA, na ABRELA. Os estagiários e voluntários não participarão. O grupo de estudo será submetido a uma entrevista psicológica com cada profissional, além da aplicação do Teste de Rorschach e de Qualidade de vida MacGill. 
FUNDAMENTOS E RACIONAL: Espera-se proporcionar aos profissionais envolvidos no projeto, a possibilidade de refletir sobre si mesmos, do sofrimento psíquico do outro, a partir dos resultados.

MATERIAL E MÉTODO: descritos e apresentados os instrumentos para coleta de dados.

TCLE: adequado.

DETALHAMENTO FINANCEIRO: sem financiamento específico R \$ 640,00.

CRONOGRAMA: 18 meses.

OBJETIVO ACADÊMICO: mestrado.

ENTREGA DE RELATÓRIOS PARCIAIS AO CEP PREVISTOS PARA: 14/5/2007 e 8/5/2008.

O Comitê de Ética em Pesquisa da Universidade Federal de São Paulo/Hospital São Paulo ANALISOU e APROVOU o projeto de pesquisa referenciado.

1. Comunicar toda e qualquer alteração do projeto e termo de consentimento livre e esclarecido. Nestas

circunstâncias a inclusão de pacientes deve ser temporariamente interrompida até a resposta do Comitê, após análise das mudanças propostas.

Rua Botucatu, 572 - $1^{\circ}$ andar - conj. 14 - CEP 04023-062 - São Paulo / Brasil

Tel.: (011) 5571-1062 - 5539.7162

2. Comunicar imediatamente ao Comitê qualquer evento adverso ocorrido durante o desenvolvimento do estudo.

3. Os dados individuais de todas as etapas da pesquisa devem ser mantidos em local seguro por 5 anos para possível auditoria dos órgãos competentes.

Atenciosamente,

\section{Prof. Dr. José Osmar Medina Pestana}

Coordenador do Comitê de Ética em Pesquisa da

Universidade Federal de São Paulo/ Hospital São Paulo 
ANEXO 3

\section{ROTEIRO DE ENTREVISTA SEMI ESTRUTURADA}

1. Naturalidade

2. Procedência

3. Sexo

4. Idade

5. Estado civil

6. Número de filhos

7. Formação acadêmica

8. Profissão

9. Fatores que contribuíram para a escolha da profissão

10. Quanto tempo de formação

11. Quanto tempo de formação

12. Expectativas da profissão foram realizadas ou não

13. Função na ABRELA

14. Quanto tempo na ABRELA

15. Carga horária de atendimento

16. Outros serviços

17. Quantos

18. Número de horas trabalhadas por dia

19. Fale de uma situação de atendimento que você se sentiu frustrado

20. Fale de uma situação de atendimento que você se sentiu ansioso

21. .Fale de uma situação de atendimento que você se sentiu raiva

22. .Fale de uma situação de atendimento que você se feliz, amparado, feliz

23. .Fale de uma situação de atendimento que você se sentiu ameaçado

24. .Fale de uma situação de atendimento que você se sentiu cobrado

25. .Fale de uma situação de atendimento que você se sentiu tristeza 


\section{ANEXO 4 \\ DEFINIÇÕES DAS ESFERAS \\ MÉTODO DE ANÁLISE ANIBAL SILVEIRA}

Coelho (1980) assim define as estruturas de personalidade, segundo o referencial teórico adotado por Silveira:

Esfera intelectual: relacionada com a observação, adaptação lógica e a captação dos fenômenos externos, e subordina o trabalho mental às exigências da realidade externa.

"....a adaptação intelectual à realidade não decorre apenas da apreciação dos eventos externos e da assimilação dos valores do ambiente, mas fundamentalmente da capacidade humana de elaborar, de modo original e criador, os dados coligidos e de comunicar o resultado das concepções e o estado subjetivo aos semelhantes." (COELHO, 1980)

Esfera da conação (do latim conatus que significa "executo"), é o setor das funções que antecedem o comportamento explícito e dirigem o trabalho mental, ou seja, capacidade de perceber, adaptar-se e comunicar-se com o meio. Abrange os dinamismos que antecedem e possibilitam as transposições de nossas disposições afetivas e elaborações intelectuais para o ambiente externo, resultando deste processo à ação explícita. São eles: a iniciativa, elemento subjetivo que desencadeia a ação explícita ou estimula a percepção e o raciocínio; manutenção que preside a estabilidade e mantem a atenção, quer dando continuidade aos atos, quer mantendo o raciocínio ou a observação e a inibição que seleciona as reações mais adequadas refreando os impulsos não pertinentes.

Esfera afetiva é considerada o setor básico da personalidade. Reúne as funções subjetivas: instintos e sentimentos que estimulam o ser humano constantemente a satisfazer as necessidades da própria existência e da espécie, e que mantêm ativo o interesse em ampliar suas relações interpessoais. Por outro lado, permite a sua integração no ambiente físico e social.Coelho (1980) define instintos como 
“(...) conjunto de funções que estimulam todo $o$ contato do individuo com a realidade externa $e$ basicamente mantém a sobrevivência individual e da espécie.Os instintos correspondem ao correlato subjetivo das funções fisiológicas básicas; das quais depende a sobrevivência física do indivíduo.

Portanto, são funções subjetivas que não diferem de outras funções afetivas, a não ser quanto ao fato de se relacionarem fundamentalmente com a individualidade, enquanto as outras regem relações com o ambiente físico e social.( $p .52)$

A autora relaciona os instintos sexual, nutritivo e outros como instintos de manutenção da vida. Destaca como principal o nutritivo, por estar ligado a todo processo metabólico do organismo e até do próprio cérebro, centralizando e dirigindo todo o metabolismo visceral. Os instintos expressam a individualidade biopsíquica. 


\author{
ANEXO 5 \\ QUESTONÁRIO DE QUALIDADE DE VIDA DE McGill \\ Versão em português (Silva HCA, Tardivo LSPC, Callegaro D) do \\ Questionário de Qualidade de Vida de McGill (Cohen R; Mount B) \\ (referência eletrônica1995/1997)
}

\title{
IDENTIFICAÇÃO:
}

Nome:

Data:

Pesquisa:

Pesquisador:

Orientador:

\section{Instrucões:}

As questões nesse questionário começam com uma declaração, seguida por duas respostas contrárias.

Números vão de uma resposta extrema até o seu oposto.

Por favor, circule o número entre zero (0) e dez (10) que é o mais verdadeiro para você.

Não há resposta certa ou errada.

Respostas completamente honestas serão mais úteis.

\section{EXEMPLO:}

Eu estou faminto

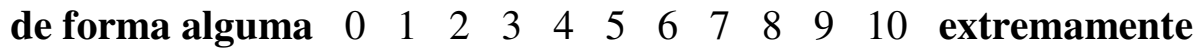

*Se você não está nem um pouquinho com fome, você deve circular zero (o)

*Se você está um pouco com fome (você terminou de comer mas ainda tem lugar para a sobremesa) você deve circular 1, 2 ou 3 .

*Se você tem fome moderada (porque está chegando a hora de comer), você deve circular 4,5 ou 6 .

*Se você está com muita fome (porque você não comeu o dia todo), você deve circular 7,8 ou 9 . 
*Se você está extremamente faminto, você deve circular o 10.

COMECE AQUI

\section{É MUITO IMPORTANTE QUE VOCÊ RESPONDA TODAS AS \\ QUESTÕES SOBRE COMO VOCÊ TEM SE SENTIDO EXATAMENTE NOS DOIS (2) ÚLTIMOS DIAS.}

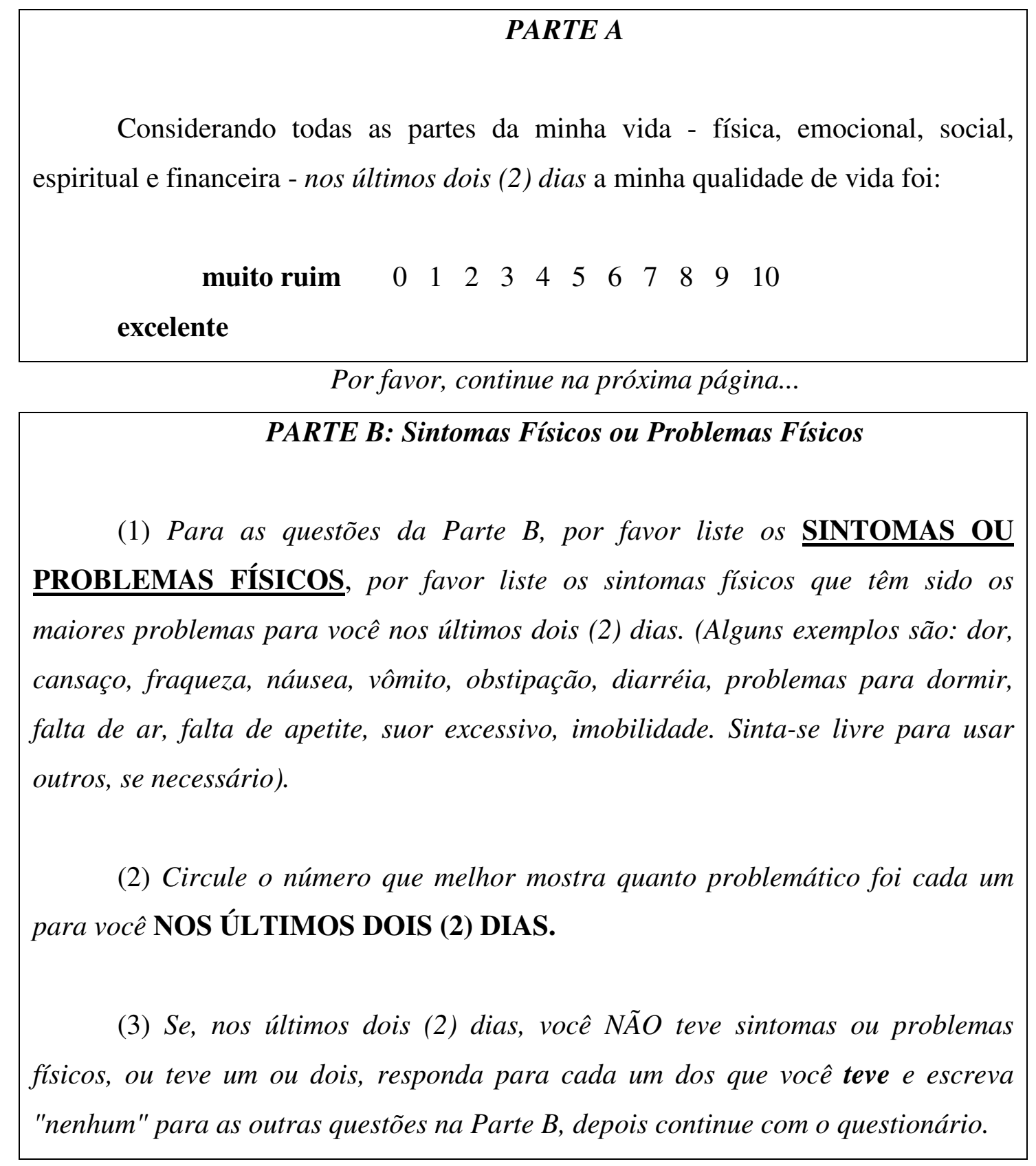


1) Nos últimos dois (2) dias, um sintoma difícil tem sido:

(escreva o sintoma)

sem problema $\quad \begin{array}{lllllllllllll}0 & 1 & 2 & 3 & 4 & 5 & 6 & 7 & 8 & 9 & 10 & \text { imenso problema }\end{array}$

2) Nos últimos dois (2) dias,

outro sintoma difícil tem sido:

(escreva o sintoma)

sem problema $\quad \begin{array}{lllllllllllll}0 & 1 & 2 & 3 & 4 & 5 & 6 & 7 & 8 & 9 & 10 & \text { imenso problema }\end{array}$

3) Nos últimos dois (2) dias,

o terceiro sintoma difícil tem sido:

(escreva o sintoma)

$\begin{array}{llllllllllllll}\text { sem problema } & & 0 & 1 & 2 & 3 & 4 & 5 & 6 & 7 & 8 & 9 & 10 & \text { imenso problema }\end{array}$

4) Nos últimos dois (2) dias,

eu tenho me sentido:

$\begin{array}{llllllllllllll}\text { Fisicamente terrível } & 0 & 1 & 2 & 3 & 4 & 5 & 6 & 7 & 8 & 9 & 10 & \text { Fisicamente bem }\end{array}$

Por favor, continue na próxima página... 
PARTE C Por favor escolha o número que melhor descreve seus sentimentos e pensamentos NOS ÚLTIMOS DOIS (2) DIAS

5) Nos últimos dois (2) dias, eu tenho estado deprimido:

$\begin{array}{lllllllllllll}\text { de forma alguma } & 0 & 1 & 2 & 3 & 4 & 5 & 6 & 7 & 8 & 9 & 10 & \text { extremamente }\end{array}$

6) Nos últimos dois (2) dias, eu tenho estado nervoso ou preocupado:

de forma alguma 012345678910 extremamente

7) Nos últimos dois (2) dias, quanto do tempo você se sentiu triste?

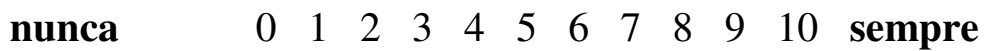

8) Nos últimos dois (2) dias, quando eu pensava no futuro, eu estava:

sem medo $\quad \begin{array}{llllllllllll}0 & 1 & 2 & 3 & 4 & 5 & 6 & 7 & 8 & 9 & 10 & \text { apavorado }\end{array}$

9) Nos últimos dois (2) dias, minha vida tem sido:

totalmente sem significado 012345678910 com muito objetivo e sem objetivo e significado

10) Nos últimos dois (2) dias, quanto eu pensei sobre toda minha vida, eu senti que, em relação a alcançar objetivos de vida, eu tenho:

feito nenhum progresso, $012345678910 \quad$ progredido para completa

$\begin{array}{ll}\text { qualquer que seja } & \text { realização }\end{array}$ 
11) Nos últimos dois (2) dias, quanto eu pensei sobre minha vida, eu senti que minha vida até este ponto tem sido:

completamente sem valor $\quad 012345678910 \quad$ muito válida

12) Nos últimos dois (2) dias, eu tenho sentido que eu possuo:

nenhum controle sobre $\quad 012345678910$ completo controle sobre minha vida minha vida

13) Nos últimos dois (2) dias, eu me senti bem sobre mim mesmo como pessoa.

discordo completamente $\quad 012345678910$ concordo completamente

Por favor, continue na próxima página...

14) Para mim, os últimos dois dias foram:

um peso $\quad 012345678910 \quad$ uma dádiva

15) Nos últimos dois (2) dias, o mundo tem sido:

um lugar impessoal e cruel 012345678910 cuidadoso e que atende minhas

necessidades

16) Nos últimos dois (2) dias, eu tenho me sentido apoiado:

de forma alguma $\quad 012345678910 \quad$ completamente Por favor, continue na próxima página... 


\section{PARTE D}

Por favor, liste ou descreva as coisas que tiveram o maior efeito na sua qualidade de vida nos últimos dois (2) dias. Por favor, conte-nos se cada coisa que você listou fez sua qualidade de vida melhor ou pior durante esse tempo. Se você precisar de mais espaço, por favor, continue no verso desta página. 
